\title{
La crítica a la alienación en El capital, a la luz de la ética argumentativa
}

\author{
Sirio López Velasco \\ Universidade Federal do Rio Grande, Brasil \\ lopesirio@hotmail.com
}

\begin{abstract}
atose
RESUMEN: El presente ensayo lee la crítica a la alienación de Karl Marx desde la perspectiva de la ética argumentativa ecomunitarista. El autor interpreta los diferentes planteamientos del filósofo alemán sobre la alienación a partir de tres premisas éticas fundamentales del ecomunitarismo: la obligación de velar por nuestra libertad individual de decidir; la obligación de realizar consensualmente esa libertad y la obligación de velar por la salud de la naturaleza humana y no humana.
\end{abstract}

ABSTRACT: The author of the following paper interprets the Marxist criticism to alienation from the perspective of the

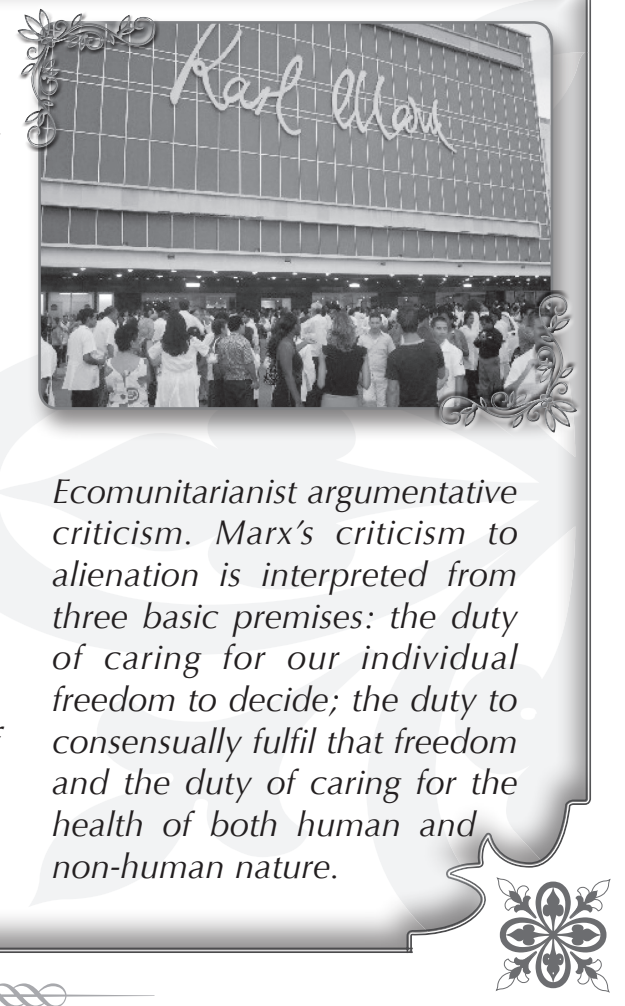

\section{Introducción}

- $n$ el presente texto pretendemos censar la crítica a la alienación producida por Marx exclusivamente en El capital (en el único de sus tres tomos publicado por él, el primero, y en los otros dos armados y publicados por Engels, a veces con agregados suyos, que evitaremos tener en cuenta) e intentar subsumirla bajo las tres 
normas fundamentales de la ética argumentativa. A esta investigación, realizada en España, decidimos asociar incidentalmente un breve diálogo con las obras de filósofos españoles que, dentro de la bibliografía a la que tuvimos acceso, más nos han interesado en el transcurso de la primera tarea; nos referimos a las obras de Ángel Prior Olmos, Aurelio Arteta, Felipe Martínez Marzoa, Ramón García de Haro, y Manuel Reyes Mate, y a la revista "Ecología Política"; no obstante y desde ya advertimos que prescindiremos de las referencias de esos autores a otros escritos de Marx, incluso los de su madurez (como el inédito capítulo VI de El capital, los Grundrisse de 1857-1858, los Manuscritos de 1861-1863, o la Crítica al programa de Gotha, las cuales son, a veces, fuentes abundantemente citadas).

"Estar alienado de" significa "estar separado de", como lo entiende la terminología jurídica al considerar como un acto de alienación, la separación de un bien que ocurre en una venta, cesión o préstamo. Vale la pena que recordemos que el español usa una sola palabra, "alienación", para traducir dos términos usados por Marx: "entfremdung" y "entäußerung"; el primero connotando por su raíz la "extrañeza" causada por la separación ("entfremdem" es "extrañar" y "fremd" el o lo que es "extraño") y el segundo la situación de "desposeerse de" (entäußern significa: deshacerse de", "desprenderse de", "desposeerse de"), también causada por la separación. Nota Arteta (p. 212, AA, de ahora en adelante) que "fremdheit" designa globalmente "separación, independencia, sustantivación, etc., a las que hay que añadir las notas de poder, dominio, sometimiento, hostilidad, antagonismo, contraposición y similares" que configuran el "fenómeno total de la alienación"; y más adelante nota que "en su forma social capitalista las cosas se alienan frente a la totalidad social, que en el proceso social se da un sometimiento general al movimiento y leyes de las cosas 'valorizadas' o 'capitalizadas'" (p. 217); la alusión a la "totalidad social" nos parece aquí ambigua y discutible, pero AA dice de inmediato que "no cabe duda que la modalidad más resaltada por Marx de la alienación de las cosas bajo su determinación capitalista es su substantivación y poder sobre los individuos mismos, enajenación que tiene lugar en la producción material, en el verdadero proceso de la vida social de esos individuos"(p. 217), como lo destacó Marx. Por mi parte juzgo que lo que preocupa a Marx en su crítica al capitalismo es el hecho de que en ese modo de producción y de vida, el individuo (en especial es el obrero el objeto de sus desvelos, pero también el capitalista y sus representantes), se encuentra mutilado e impedido de desarrollarse como individuo universal (o sea, desarrollado en todas sus vocaciones y aptitudes) porque se encuentra separado (o 
sea "alienado") de diversos modos: del otro individuo, con y no contra cuya libertad debería realizarse la suya propia, de sí mismo, y de múltiples instancias donde se dan y/o plasman las relaciones interindividuales. No olvidemos que Marx, siguiendo a Aristóteles (para quien el ser humano es un ser político), considera al individuo como un nudo de la red de relaciones sociales en las que está insertado.

Recordemos nuevamente que de los tres tomos publicados bajo el título de Das Kapital (Marx imaginó que serían cuatro y el cuarto salió póstumamente bajo el título de "Historia crítica de la teoría de la plusvalía"), Marx pudo publicar en vida y bajo su supervisión sólo el primer tomo (que definió como tema "El proceso de producción del capital"), mientras que los otros dos se debieron a la actividad recolectora-ordenadora de su albacea, Federico Engels, por lo que tienen a veces la forma de una colcha de retazos repetitivos e inconclusos, pero no por ello menos ricos que los textos del primer tomo. Así, nos interesa aquí mostrar como afloran en los tres tomos, incluso en sus repeticiones, que muestran la importancia que daba Marx al tema, las anotaciones de nuestro autor, en su obra cumbre, sobre la alienación. [En las citas identificamos los tres tomos, respectivamente por T. $1, \mathrm{~T}$. 2 y T. 3; "Libro" se abrevia en "L", "Sección" en "S", y "Capítulo" en "Cap"; hemos cotejado la versión española con una edición en alemán, y cuando fue preciso la hemos corregido a la luz de esta última].

\section{La hipótesis de subsunción}

E n estas notas nos proponemos realizar un primer intento de subsumir las diversas observaciones de Marx acerca de la alienación, constantes en El capital en una $u$ otra de las tres normas fundamentales deducidas en nuestra ética argumentativa ecomunitarista.

Como se sabe (ver, entre otros, López Velasco 2003b, o en 2003c) hemos deducido como primera norma de la ética la obligación de velar por nuestra libertad individual de decidir, como segunda norma, la obligación de realizar consensualmente esa libertad, y como tercera norma, la obligación de velar por la salud de la naturaleza humana y no humana (por lo menos desde el punto de vista productivo).

La lectura de El capital permite verificar que hay en sus tres volúmenes diversas observaciones sobre diferentes facetas de la alienación. Así, el primer volumen contiene el célebre pasaje sobre el fetichismo, pero es menos sabido que en el tercero también se usa ese término, 
y que a él deben juntarse las observaciones relativas a la inversión dialéctica entre sujetos y objetos, a la objetivación del trabajador, y al despotismo del capital, que aparecen tanto en el primero como en el último volumen; observaciones sobre la alienación en general se encuentran en los tres volúmenes; las notas sobre la alienación en relación a los medios de vida y de producción son frecuentes, en los tres volúmenes; la alienación en relación al trabajo es mencionada en el primero, y la relativa al producto del trabajo aflora en trechos de los tres volúmenes; la alienación en relación a sí mismo es asunto que figura en los dos primeros, y la alienación en y respecto a la actividad productiva consta en los tres volúmenes; finalmente, la alienación en relación al otro individuo (tanto para el trabajador como para el capitalista, e incluso para el campesino y aún el gerente) aparece de forma explícita en el último volumen.

Las presentes notas intentan una primera aproximación a algunas de esas observaciones marxianas, para luego intentar subsumirlas en una y/o en otra de las tres normas fundamentales deducidas en nuestra ética argumentativa ecomunitarista. Así, por ejemplo, postulamos como hipótesis que quizá podrían ser subsumidas, entre otras,: a) por la primera norma, diversas limitaciones a la libertad individual impuestas por la alienación en relación a sí mismo, al trabajo, al producto del trabajo y a la actividad productiva, b) por la segunda norma, diversas violaciones del consenso impuestas por la alienación en relación a los medios de vida y de producción, a la actividad productiva y vigente en las relaciones interindividuales de producción y de comunicación existentes en la empresa capitalista (marcada por la preponderancia del acto lingüístico de la "orden"), y c) por la tercera norma, diversos atentados a la salud de la naturaleza humana y no humana impuestos por la alienación en relación a sí mismo y al otro, a los medios de producción y de vida, a la actividad productiva y a la naturaleza no humana.

\section{La ética argumentativa y el ecomunitarismo}

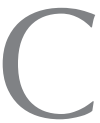

reo que es un "universal humano" presente en todas las culturas el hecho de que las personas se preguntan: "¿qué debo hacer?" (en tal o cual circunstancia); y que esa pregunta contiene la carga de una auto-obligación que, si no está cumplida, independien- temente de cual sea la opinión de otros o la sanción o premio social, deja en la persona el desagradable sabor de la insatisfacción para consigo mismo. Esa auto-obligación es propia de la ética y la moral.

Ahora bien, si ética y moral se ocupan del contenido y la forma 
de las respuestas que damos a la pregunta "¿qué debo hacer?", ambas no lo hacen de igual manera. Mucha gente ha apuntado esa diferencia; pero en lo que me respecta la establezco a partir de un criterio lingüístico simple: mientras que la Moral se contenta con respuestas de la forma "debo hacer tal cosa", o, "no debo hacer tal cosa", la Ética va más allá y nos embarca en la difícil tarea de las justificaciones; por eso sus respuestas son del tipo "debo hacer tal cosa, porque.....", o, "no debo hacer tal cosa, porque..."; y conste que después de ese "porque" va una frase sobre cuya verdad podemos discutir.

Nótese que no se puede discutir si es verdad la expresión "¿Qué hora es?; sencillamente porque en las lenguas humanas las preguntas no pueden ser verdaderas o falsas; sólo pueden serlo algunas de las respuestas que damos a esas preguntas. En general e incluyendo esas respuestas, las expresiones que pueden ser discutidas como siendo verdaderas o falsas se llaman "sentencias" o "enunciados".

Esa discusión es posible y necesaria para la ética. En efecto, recién dijimos que después del "porque" viene una frase discutible en términos de verdad o falsedad. Y las cosas se organizan como sigue: $\mathrm{si}$ aceptamos la verdad de esa frase, entonces asumimos la obligación expresada antes del "porque", como "deber"; y si consideramos que la frase después del "porque" es falsa, entonces no adherimos ni creemos éticamente legítimo que nadie sea instado a adherir a la obligación expresada antes del "porque". (La única restricción que se impone a este juego es que la frase que siga al "porque" trate del mismo asunto que la obligación que lo precede). Y para que las cosas queden más claras muchas veces habrá que explicitar las circunstancias en que opera la obligación, para que la discusión de la verdad o falsedad de la frase que sigue el "porque" sea capaz de arribar a una conclusión.

Así se dirá, por ejemplo: "Debo respetar a mis padres porque el respeto a mis padres mantiene la familia unida y yo quiero mantener la familia unida".

Así, en este caso, dada la verdad de la expresión (de hecho son dos, en este caso, y ambas verdaderas), que sigue a la palabra "porque" se revela legítima la obligación que precede aquella palabra. ( $Y$ la negación de aquella obligación sería éticamente ilegítima, por ser falsa, parta el caso considerado la frase "el respeto a mis padres mantiene la familia unida y yo quiero mantener la familia unida").

Lo que me interesa destacar es que mi manera de distinguir la Moral de la Ética permite que, usando de la forma lingüística apropiada (a saber la obligación, seguida de "porque", seguida de una frase discutible en términos de verdad o falsedad), toda persona, por su apreciación de lo que sea verdadero o falso (en las circunstancias del caso 
analizado) pueda decidir sin equívocos (y ponerse de acuerdo con otra sobre ello), cuál obligación es éticamente legítima y cual no.

En otras palabras, por su propia estructura las expresiones éticas tienen la capacidad de superar (al menos dentro del mismo horizonte cultural, y aquí pienso en el llamado "occidental") el "relativismo moral", al poder definir, en base a lo que se juzgue verdadero o falso para el caso en cuestión, lo que constituye obligación legítima y lo que no.

O sea, que si ciertas personas (pertenecientes al mismo horizonte cultural) nunca pueden dialogar desde la diferencia que en materia de obligaciones morales los separa, sí pueden hacerlo y llegar a un acuerdo cuando lo hacen al modo ético, o sea, dando las justificaciones (referentes al contexto de cada caso) que apoyan la obligación en cuestión.

Claro que lo que juzgamos verdadero o falso cambia con nuestros conocimientos y experiencias; de ahí que lo que es éticamente legítimo para nosotros y nuestros interlocutores, también está sometido a ese proceso de cambio. O sea, las normas éticas (que pueden ser numerosísimas, en rigor infinitas), por la estructura que las caracteriza en mi propuesta, tienen la propiedad de no ser dogmáticas (o sea prisioneras de algún dogma incuestionable) y estáticas (o sea inmutables para siempre), sino, por el contrario, argumentativamente renovables según lo que consideremos (discutiendo con los otros) verdadero o falso (para el contexto y la cuestión analizada). Ello las distingue de las normas morales, que en la simplicidad del "debo" o "no debo", son incapaces de enfrentar y vivir esta dinámica.

Si hemos dicho que algunas expresiones, como las preguntas (y las obligaciones) no son pasibles de discusiones en términos de "verdad" o "falsedad" (porque ello sólo es posible en el caso de las afirmaciones y negaciones de "sentencias" o "enunciados"), ha llegado el momento que recordemos a Austin. Este filósofo inglés, en reflexiones que fueron recogidas después de su muerte en un librito intitulado How to do things with words (Austin 1962; literalmente, ¿Cómo hacer cosas con palabras?) se preguntó cuál criterio nos podría ayudar a hacer diferencias entre expresiones para las cuales no hay lugar a la discusión en términos de "verdad" o "falsedad", porque en ellas hacemos otra cosa que describir (afirmando o negando), cosa que es función de las "sentencias". Austin propuso que tales expresiones, si no pueden ser distinguidas entre "verdaderas" o "falsas", sí pueden serlo entre "felices" e "infelices". Y agregó que una $u$ otra eventualidad dependen de que ciertas reglas hayan (o no hayan) sido respetadas. Esas reglas se refieren a la existencia de un procedimiento convencionalmente aceptado para hacer algo por medio 
de las palabras en cuestión, a que ese procedimiento sea ejecutado por las personas adecuadas y en todos sus pasos, y a que al hacerlo los pensamientos o sentimientos presentes al hacerlo sean los adecuados. Tres ejemplos, el "felicitar", el "bautizar", y el "divorciarse". Existe el procedimiento consistente en "felicitar" pronunciando las palabras "Te felicito (por tal cosa)", y ese procedimiento está disponible para ser usado por cualquier persona; no obstante (en función del tercer tipo de reglas) la felicitación será "feliz" si hay en la persona que lo usa el sentimiento-pensamiento de alegrarse efectivamente por el otro que está siendo felicitado, y será "infeliz" si éste está ausente; por ejemplo puedo felicitar a mi colega pintor diciéndole "Te felicito por la exposición"; pero ese acto será "feliz" si de veras me alegro por él por la muestra de su obra, y, por el contrario será infeliz si al pronunciar aquellas palabras pienso-siento: "Mucho más que tú, mediocre creador, me merecía yo esa exposición". (Como pueden imaginarse este ejemplo es mera invención literaria y nunca ha sucedido de verdad entre artistas).

En relación al "bautizar" el acto será infeliz si la persona que pronuncia las palabras no es un sacerdote, aunque todo el rito lingüístico y gestual sea el prescrito por el procedimiento convencionalmente aceptado (en el contexto de la cultura cristiana), y también estén presentes los sentimientos- pensamientos adecuados; o sea, aquí la "infelicidad" estaría decretada por la violación del segundo tipo de reglas.

Último ejemplo: será "infeliz" mi intento de divorciarme de mi mujer pronunciando una $y$ mil veces la frase "me divorcio de ti", porque en el caso de la cultura occidental dentro de la cual hemos contraído matrimonio, no basta la palabra del marido para consumar el divorcio; o sea, el procedimiento usado no es convencionalmente aceptado para practicar el acto pretendido; (al parecer, sí lo es en el mundo musulmán, pues allí el derecho de "repudio" concedido al marido en mucho se asemeja al acto aquí descrito; he aquí un primer problema en nuestro diálogo intercultural).

Al fin de sus reflexiones, Austin percibió que hasta en los casos de las "sentencias" era posible discernir en términos de "felicidad" e "infelicidad" (con lo que relativizaba la tradicional división entre "verdadero" o "falso" con la que hasta entonces se las había tratado).

Sin considerar el último punto citado, a partir de Austin sustento que: a) todos tenemos la capacidad de discernir entre actos lingüísticos "felices" e "infelices", y en el uso normal del lenguaje todos pretendemos producir actos "felices", b) la "felicidad" de los actos lingüísticos dependen de que ciertas reglas hayan sido respetadas o no, c) esas reglas son condiciones de 
la "felicidad" del acto lingüístico en cuestión. La pregunta es: ¿esto es así en todas las culturas?

Partiendo de la base de que todos pretendemos realizar ejecuciones felices de la pregunta que instaura el universo ético, a saber, "¿Qué debo hacer?", me pregunto: ¿cuáles son las condiciones de la "felicidad" de tal pregunta?

Pienso que por esa vía descubriremos normas que ya están presentes en la gramática profunda de esa pregunta y que se presentan como normas éticas (según la estructura que antes hemos explicitado). Creo que sucede con esas normas algo parecido a lo que acontece con las reglas gramaticales de nuestra lengua materna; o sea, que las conocemos y usamos sin tener conciencia de ellas antes de ir a la escuela, y cuando allá Ilegamos, descubrimos ahora de forma reflexiva y distinta cuáles son esas reglas; a partir de ese momento en el uso de la lengua quedamos por ellas obligados (aunque podemos decidir no respetarlas, nunca, o en ciertas circunstancias). De manera similar defiendo la idea de que al investigar las condiciones de "felicidad" de la pregunta "Qué debo hacer?" Ilegaremos a detectar normas éticas que desde antes nos obligaban sin que lo supiésemos, y que ahora pasan a obligarnos de forma reflexiva (aunque podemos decidir apartarnos de ellas a cualquier momento). Claro que la ética vive del hecho de que no nos sentimos bien cuando hacemos esto último y que tal sensación no está divorciada del hecho de que percibimos que en tal caso estamos fracasando en el uso "feliz" del lenguaje que contribuye a hacernos humanos.

\section{Las tres normas fundamentales de la Ética}

$\mathrm{P}$ ido al lector: a) que no se desanime con el aspecto de "trabalenguas" que parece tener la formulación de las normas éticas que deduciremos al investigar las condiciones de "felicidad" de la pregunta que instaura el universo ético; (cuando se ve su enorme importancia y alcance en todas las facetas de la vida, esa sensación de "entrevero de palabras" habrá sido superada por la de la luminosidad que su aplicación nos aporta en cada caso) y b) que me diga si ellas valen o no en su cultura..

a) De la Libertad

Preguntar(se) "¿Qué debo hacer?" presupone que podría hacer más de una sola cosa; si sólo puedo hacer una, entonces, no cabría la pregunta. Por ejemplo, este lápiz que tengo en la mano a un metro del suelo no se pregunta, cuando lo suelto, qué debe hacer; si estamos en la Tierra el lápiz caerá por efecto 
de la gravedad; si estamos en una nave espacial en órbita terrestre el lápiz permanecerá flotando, debido a la ausencia de gravedad. Pero los seres humanos al preguntarnos qué debemos hacer presuponemos por ese mismo acto que podemos asumir en cada circunstancia más de una conducta. Ahora bien, poder hacer más de una cosa en cada circunstancia, presupone poder elegir entre diversas alternativas de acción. Mas, para tener esa capacidad de elegir entre diversas alternativas de acción hay que tener libertad de hacerlo.

Así, interrogando lo que está detrás y en la raíz de la pregunta "¿Qué debo hacer?" hemos descubierto la condición para su realización "feliz". (Recordando que suponemos que todos deseamos realizar ejecuciones felices de tal pregunta), podemos concluir entonces que hemos llegado a una norma ética embutida en la gramática de la pregunta considerada que se deja resumir como sigue:

"Debo luchar para garantizar mi libertad de elegir, porque mi libertad de elegir es condición de la realización feliz de la pregunta "¿Qué debo hacer?"

Obsérvese que esta norma, contrariamente a lo que han dicho muchos eminentes filósofos, no afirma que los seres humanos seamos libres. Lo que ella nos plantea es la obligación de luchar por nuestra libertad de elegir.

Eso significa que ella nos emplaza a luchar contra todas aquellas coacciones y trabas que limitan esa libertad. Ahora bien, hay otras dos normas que trazan el círculo donde cobra legitimidad esta primera.

b) Del consenso

Karl-Otto Apel (1973 y 1985) nos mostró que las ciencias funcionan, aunque a veces los propios científicos no se den cuenta de ello, a partir de tres normas éticas. Ellas son, a) decir lo que se cree ser la verdad, b) renunciar al egoísmo en la búsqueda colectiva de la verdad, y, c) aceptar a cualquier ser humano como compañero legítimo en esa búsqueda (Apel 1985, fin del Tomo II). No habría ciencia tal como la conocemos si ante cada artículo científico nos preguntásemos: ¿este/a señor/a está diciéndonos lo que cree ser verdadero o nos está engañando (por bromear o por hacerse el importante)? Practicar ciencia supone que decimos efectivamente lo que creemos ser en cada caso la verdad y leer/oír a los otros con esa misma expectativa. Por otro lado, la historia de la ciencia ha demostrado que nadie es dueño de la verdad. Hoy más que nunca, grandes equipos, en laboratorios no menos grandes, son los encargados de renovar día a día el conocimiento científico, mostrando que lo que creíamos saber ayer era inexacto o incompleto y que las cosas son diferentes de lo que habíamos imaginado. Esos equipos y laboratorios hacen públicos sus resultados en seminarios, congresos, revistas, libros, y, cada vez con más frecuencia, en Internet, a través de 
la cual mantienen comunicación casi permanente entre sí. Cada científico se incorpora a esa búsqueda colectiva de la verdad, nunca plenamente alcanzada, pero sin cesar perseguida por el conjunto de las personas dedicadas a (cada área de) las ciencias. Por último, nadie puede ser descartado de esa carrera sin fin hacia la verdad. A principios del siglo XX, cuando Einstein publicó su primera versión de la Teoría de la Relatividad, era un simple empleado en una oficina de registro de patentes de inventos. Es cierto que, al no pertenecer a ninguno de los equipos de los centros de investigación más célebres de la época, esa primera publicación careció del impacto inmediato de la ceremonia del Óscar; sin embargo, pese a no integrar los centros de investigación famosos de la época, Einstein no fue ignorado por los científicos. Por el contrario, muy pronto sus ideas fueron tema del día entre los físicos más conocidos y el propio Einstein fue llamado a incorporarse a los círculos científicos por ellos frecuentados

Por mi parte creo poder afirmar que, lo que Apel descubrió en el universo del discurso descriptivo de las ciencias, puede ser aprovechado para el juego lingüístico de las preguntas (y dentro de él para la que nos guía en toda esta caminata). Así creo que preguntar presupone que: a) nos abrimos a la búsqueda colectiva de la respuesta, y, b) que creemos que nuestro(s) interlocutor(es) responderá(n) diciendo lo que juzgan verdadero o correcto en cada caso. Noten que eso, como en las ciencias, no significa que estoy obligado a concordar con mi interlocutor; por el contrario, es a partir de la libertad de discordar y discutir con él, que se renueva la búsqueda de la verdad o corrección de la respuesta pretendida. Claro, que también, como en las ciencias, el hecho de suponer que existe una respuesta apropiada para cada caso, indica que la búsqueda colectiva se orienta por la idea de que es posible arribar a un consenso sobre el asunto de que se trate. Noten que todo esto explica el embarazo del orador que al hacer una "pregunta retórica" ( aquella seudo-pregunta destinada a ser respondida sólo por el mismo que la formula), oye desde el auditorio una respuesta distinta a la que él mismo pretende dar en la secuencia de su exposición; por ejemplo, después de varias ponderaciones moralizantes que tienden a asociar el alcohol al diablo, el orador puede formular la pregunta retórica, ¿debemos prohibir la bebida?, para la que ya tiene preparada la respuesta positiva, y oír con desagrado cómo desde el fondo del público que se aglomera bajo la sombra de los árboles del parque, una voz de borrachito dice alto y claro: “„No!". El embarazo viene del hecho que la pregunta efectiva (y no la seudo-pregunta aparente que es la de carácter retórico) abre efectivamente el campo de las respuestas a la participación colectiva de la que ningún ser humano puede ser excluido. Un ejemplo que presencié 
personalmente me confirma la validez de esta interpretación; sucedió que en un ómnibus bastante lleno de un país latinoamericano una señora preguntaba en voz baja a su compañera de asiento si debía o no separarse de su marido infiel; para su asombro, a los pocos minutos buena parte del ómnibus opinaba sobre su pregunta; unos para defender la separación, juzgando inaceptable la infidelidad, y otros pidiéndole paciencia porque era notorio que los hombres, eternos adolescentes hasta los 40, comenzaban a entrar en juicio con la llegada de las canas, y entonces las cosas empezaban a arreglarse.

De lo dicho podemos deducir la segunda norma ética que así resumimos:

Debemos buscar consensualmente una respuesta para cada instancia de la pregunta "¿Qué debo hacer?" porque hacerlo es condición de la realización feliz de tal pregunta.

Se ve que tal norma viene a poner un límite claro al ejercicio legítimo de la primera, porque ahora resulta evidente que el ejercicio de mi libertad de decidir solamente tiene legitimidad ética cuando se combina con la búsqueda del consenso con los otros. Lo que la segunda norma plantea es el desafío de que mi libertad de decidir no opere contra la libertad de decidir de los otros, sino con ella. Ella permite cuestionar desde la ética el aserto que dice " Mi libertad termina don- de empieza la de los otros", porque este aserto presupone que ambas libertades han de contraponerse; podemos preguntar si tal presuposición, en vez de retratar una constante de la condición humana, no sería el reflejo de una expresión histórica de tal condición (entre otras posibles), a saber la característica de la sociedad capitalista (Marx 1844).

Los filósofos llamados "posmodernos" creyeron éticamente legítimo defender la idea del disenso y la diferencia contra el consenso (porque, dijeron, en nombre de la razón que lo reivindica muchos crímenes fueron cometidos); sin entrar a discutir el contendido, el fondo y el trasfondo histórico-político de estos posmodernos, quiero llamar la atención sobre una flagrante auto-contradicción de estos señores supuestamente muy listos; dar cursos y conferencias y escribir artículos y libros sobre la (supuesta) prioridad del disenso, no significa renunciar-superar el consenso, sino precisamente lo contrario; significa intentar hacer consenso sobre la importancia del disenso; total: por su práctica los posmodernos muestran a las claras la falsedad de su teoría, reafirmando el consenso como idea-guía de nuestra acción (pautada explícita o implícitamente por lo que creemos deber hacer).

c) La norma ecológica

Recuérdese que, según Austin, la existencia de un determinado procedimiento convencionalmente aceptado es condición básica de 
felicidad del acto lingüístico de que se trate en cada caso. Así, es condición de la felicidad de la pregunta "¿Qué debo hacer?" la existencia del acto lingüístico de "preguntar". Ahora bien, de lo que nos dicen nuestros actuales conocimientos sobre formas de comunicación entre los seres vivos, podemos concluir que solamente el lenguaje humano posee "preguntas". A su vez (y aunque las computadoras ahora nos hacen la competencia, no olvidemos que somos nosotros quienes las fabricamos, les ponemos dentro los programas con sus lenguajes respectivos y las hacemos funcionar), sólo los seres humanos saben hacer uso cabal y completo del lenguaje humano. (Animales que entienden algunas palabras no saben leerlas en un libro). Mas ahora viene la pregunta del millón: ¿qué define a un ser como "humano"? Si respondemos que es el lenguaje nada avanzaremos porque estaremos girando en círculos. Con Marx puedo esgrimir otro rasgo distintivo: el trabajo. Por él el hombre ha transformado el planeta a su imagen y semejanza, para bien y para mal. Causa asombro y preocupación el hecho de que hoy no hay prácticamente ningún rincón del planeta que escape al poder transformador, por vía directa o indirecta, del trabajo humano. En los antiguos pantanos que hasta el siglo XVII rodeaban París se edificaron palacios y jardines; en nuestros modestos jardines latinoamericanos vuelan los gorriones, traídos sin querer por algún barco venido de Inglaterra, no se sabe exactamente cuándo; florestas en cualquier lugar del mundo están siendo literalmente quemadas por lluvias ácidas provocadas por emanaciones industriales y de automóviles que operan, a veces, a mucha distancia de allí.

A pesar de su increíble variedad todo trabajo humano reposa en tres constantes: el sujeto que produce, el instrumento a través del cual produce, y el objeto sobre el que opera el sujeto a través del instrumento. El sujeto es un ser humano, mamífero perteneciente a la naturaleza terráquea; el instrumento a través del cual opera el sujeto puede ser desde una piedra usada para tallar otra, hasta la máquina computadorizada de comando digital, o la propia computadora; en fin, el objeto es siempre algún material extraído de la naturaleza (desde la piedra antes citada, hasta el gas licuado que sirve de combustible al cohete, o: ¡la propia "información"!, que es material especial producido por ese ser natural particular que es el ser humano). Nótese que las tres constantes que hacen posible el trabajo remiten a la naturaleza: el ser humano, el instrumento y el objeto. Pero remiten a una naturaleza que sea apta para el trabajo. Y así, llegando al inicio de esta larga escalera, alcanzamos a la tercera norma ética que reza:

Debo preservar-regenerar una naturaleza sana desde el punto de vista del trabajo, porque ello es condición de la felicidad de la pregunta: “Qué debo hacer?" 
Esta norma es capaz de orientarnos en la decisiva cuestión ecológica que tanto se discute hoy. Ya oigo voces alertándome: “¡no hacía falta tantos vericuetos para llegar a la conclusión de que debemos preservar la naturaleza, porque eso es evidente!". Y yo respondo: no se olvide que a alguien tan inteligente como Aristóteles le parecía "evidente" que hay seres humanos destinados naturalmente a ser esclavos ( o sea, que la esclavitud, siendo algo "natural", no podría ser nunca abolida); tampoco se olvide que la temática ecológica no fue reconocida como tema capital por la cultura Ilamada "occidental" (hoy dominante en el planeta), sino muy recientemente, en la segunda mitad del siglo $\mathrm{XX}$; y por último, nótese que la tercer norma hace parte de un conjunto también formado por las otras dos, con lo que se configura un claro perfil socio-ambiental en cuyo interior no cabe disociar las cuestiones sociales (de la libertad individual y del consenso) de las ecológicas.

Confieso que la tercera norma, así como la hemos deducido, presenta un claro carácter utilitario, en la medida que plantea la preservación-regeneración de la naturaleza a la luz de su potencialidad productiva. Admito esa limitación, pero, ¡qué le vamos a hacer!; hasta ahí y no más lejos, me condujo la capacidad deductiva propia a nuestra propuesta ética en su forma actual; ojalá pasos ulteriores (¿inspirados por otras culturas?) puedan condu- cirnos hasta la preocupación lúdica y estética gratuita en lo que respecta a la preservación-regeneración de una naturaleza sana en nosotros, los otros seres humanos y la naturaleza no-humana en general. No obstante espero que sea evidente que, esa tercera norma, a pesar de su limitación, mucho nos ilumina en lo relativo a importantes cuestiones del campo de la economía, la ecología, la erótica y la pedagogía (como lo muestro en López Velasco 19961997-2000), en las que al parecer podemos alcanzar significativas convergencias interculturales.

Postulo que las tres normas éticas orientan hacia la construcción de un nuevo orden socio-ambiental planetario que Ilamo "ecomunitarismo" y que hace figura de horizonte utópico de la acción. El ecomunitarismo (quizá nunca alcanzable, pero indispensable estrella-guía) representa la efectiva constitución histórico-real del género humano en una asociación planetaria de productores libremente asociados (Marx 1844) que satisfacen solidariamente las necesidades del desarrollo multifacético de cada uno en un intercambio preservador-regenerador con la naturaleza no-humana. [Como me ocupo y me ocuparé de Marx, porque mucho me inspira su posición crítico-utópica ante el capitalismo, es bueno aclarar que mi posición, fundamentada en las tres normas antes deducidas, es por completo independiente del éxito o fracaso de las tesis centrales de Marx referentes a la plusvalía, la tasa de ganancia y su disminución]. 
En el ecomunitarismo las "órdenes" y toda relación impositiva asimétrica han sido superadas por los acuerdos consensuales, que rigen a) a nivel erótico, transformado en dimensión del encuentro de dos libertades que comparten el placer, b) en lo pedagógico, con la superación de la educación "bancaria" por la "problematizadora" (Freire 1970), c) en la política, devuelta a su sentido original de "conjunto de ciudadanos que organizan la polis", practicando la democracia directa y sometiendo a las bases las funciones representativas que se hicieren necesarias, y, a nivel mundial, sustituyendo la actual ONU por una efectiva asamblea cooperativa de pueblos, aboliéndose el actual abismo entre naciones "decididoras" y "no-decididoras", que se expresa en el derecho de veto y la dominación militar.

\section{Breve recuerdo de la primera sistematización marxiana acerca de la alienación: Los Manuscritos de París, de 1844}

N uestro análisis parte de la crítica del trabajo alienado hecha por Marx en la parte final del primero de los Manuscritos económico-filosóficos escritos en París en 1844; allí las secciones XXII, XXIII, XXIV y XXV (esos números romanos son usados en las diversas ediciones de esa obra de juventud) están explícitamente dedicadas al trabajo alienado [citaremos los Manuscritos por su números (I, II, y III), seguidos de la página en la edición española que usamos, cotejándola y corrigiéndola a la luz del original alemán; las itálicas y los subrayados son de Marx].

Marx presenta la alienación en relación al producto del trabajo como sigue. "La objetivación aparece como pérdida del objeto a tal punto que el trabajador se ve privado de los objetos más necesarios no solamente para la vida sino también para el propio trabajo... El objeto que el trabajo produce, su propio producto, se enfrenta con él como un ser extraño, como un poder independiente del productor". (XXII) En resumen, eso quiere decir que el producto producido no pertenece al asalariado sino al dueño del medio de producción que lo emplea; a tal punto que puede acontecer que un trabajador que produce alimentos pase hambre por no ser el dueño de los mismos, lo que lo habilitaría a usarlos para saciar su necesidad. Nótese que para saciar esa necesidad el trabajador no puede recurrir a la naturaleza (incluso si se trata de una floresta que nada debe al trabajo humano), porque la misma ha sido privatizada y pasó a ser propiedad del latifundista-capitalista. Es verdad que "el trabajador no puede crear nada sin la naturaleza, sin el mundo exterior sensible. Esta es la 
materia en la cual su trabajo se realiza, en la que obra, en la que y con la que produce (XXIII); es verdad que "la universalidad del hombre aparece en la práctica justamente en la universalidad con la que hace de la naturaleza toda su cuerpo inorgánico, tanto porque ella es: 1 ) un medio de subsistencia inmediato, como, 2) la materia, el objeto y el instrumento de su actividad vital. La naturaleza es el cuerpo inorgánico del hombre, o sea la naturaleza en cuanto ella misma no es cuerpo humano. Que el hombre vive de la naturaleza quiere decir que la naturaleza es su cuerpo, con el cual ha de mantenerse en proceso continuo de intercambios para no morir. Que la vida física y espiritual del hombre está ligada con la naturaleza no significa otra cosa sino que la naturaleza está ligada consigo misma, pues el hombre es una parte de la naturaleza" (XXIV). Pero "el trabajo alienado aliena del hombre la natureza." (XXIV). Así quien no es dueño de la tierra no puede recurrir a ella para coger sus frutos que satisfagan sus necesidades (ni siquiera, por ejemplo, frutas silvestres a la orilla del arroyo, pues el mismo hará parte de una estancia que tiene dueño) ni materiales que, una vez transformados por el hombre, ele podrían satisfacer sus necesidades, directa o indirectamente mediante el cambio o la venta (como, por ejemplo podría servir un árbol de esa misma floresta, convertida en mesa para ser usada o vendida/cambiada por otros bienes necesarios para el trabajador).
La alienación en relación al propio trabajo es presentada como sigue: "El propio trabajo se transforma en un objeto del cual el trabajador solamente logra apropiarse con el mayor de los esfuerzos y las más extraordinarias interrupciones..." (XXII). En concreto eso significa que el asalariado está siempre a merced del desempleo: a) porque no es él quien decide si tendrá empleo, sino el capitalista (o un representante suyo), b) porque cuando consiguió una plaza, no está nunca a salvo de perderla a cualquier momento (también por decreto unilateral del capitalista).

Ahora bien, si el trabajador tiene la "felicidad" de conseguir un empleo, la alienación también se configura en el "...acto de la producción, dentro de la actividad productiva misma" (XXIII). [En el trabajo alienado] "el trabajo, la actividad vital, la vida productiva misma, aparece ante el hombre solamente como un medio para la satisfacción de una necesidad, de la necesidad de mantener la existencia física. ... Ahora bien, en la forma de la actividad vital reside todo el carácter de una especie, su carácter genérico, y la actividad libre, consciente, es el carácter genérico del hombre. [Pero en el trabajo alienado] la vida misma aparece tan sólo como medio de vida..."(XXIV).

"Una consecuencia inmediata del hecho de estar alienado el hombre del producto de su trabajo, de su actividad vital, de su ser genérico, es la alienación del hombre res- 
pecto del hombre. Si el hombre se enfrenta consigo mismo, se enfrenta también al otro. Lo que es válido respecto de la relación del hombre con su trabajo, con el producto de su trabajo y consigo mismo, vale también para la relación del hombre con el otro y con el trabajo y el producto del trabajo del otro hombre... El ser extraño al que pertenecen el trabajo y el producto del trabajo, a cuyo servicio está aquél y para cuyo placer sirve éste, solamente puede ser el hombre mismo. Si el producto del trabajo no pertenece al trabajador, si constituye frente a él un poder extraño, esto sólo es posible porque pertenece a otro hombre que no es el trabajador. Si su actividad [del trabajador] es para él dolor, habrá de ser gozo y alegría vital para otro" (XXIV).

Marx también subraya que esas diversas dimensiones del trabajo alienado determinan la alienación del sujeto (en especial del trabajador, pero también del capitalista) en relación a sí mismo. Así Marx recuerda que por el hecho de alienar al ser humano de la naturaleza, el trabajo alienado lo aliena de si mismo (puesto que el ser humano es una parte de la naturaleza), y destaca que hay "auto-alienación" en la alienación de la actividad productiva en la medida en que en ella "su vida personal" se le aparece al trabajador como "una actividad dirigida contra él, independiente de él, que no le pertenece" (XXIII). En el trabajo alienado "el trabajo es externo al trabajador, es decir no pertenece a su ser;...en su trabajo, el trabajador no se afirma, sino que se niega; no se siente feliz, sino desgraciado; no desarrolla una libre energía física y espiritual, sino que mortifica su cuerpo y arruina su espíritu. Por eso el trabajador sólo se siente "en sí" [bei sich] fuera del trabajo y se siente "fuera de sí" [außer sich] en el trabajo. Está "en casa" [zu hause] cuando no trabaja y cuando trabaja no está "en casa". Su trabajo no es, así, voluntario, sino forzado, [es] trabajo forzado. Por eso no es la satisfacción de una necesidad, sino solamente un medio para satisfacer las necesidades fuera del trabajo. Su carácter extraño se evidencia claramente en el hecho de que tan pronto como no existe una coacción física o de cualquier otro tipo, se huye del trabajo como de la peste. El trabajo externo, el trabajo en que el hombre se aliena, es un trabajo de autosacrificio, de ascetismo. En último término, la exterioridad del trabajo se muestra para el trabajador en el hecho de que aquél... no le pertenece sino que pertenece a otro" (XXIII). [Ese "otro" apuntado por Marx es el capitalista, o sea el dueño de los medios de producción]. "De eso resulta que el hombre (el trabajador) solo se siente libre en sus funciones animales (en el comer, beber, procrear y todo lo referente a la habitación y al vestuario) y, en cambio, en sus funciones humanas se siente como animal. Lo animal se convierte en lo humano y lo humano en lo animal. Claro que comer, 
beber, procrear, etc. son también auténticas funciones humanas. Pero en la abstracción que las separa do contexto restante de la actividad humana y las convierte en fin único y último, son animales." (XXIII).

Ese hecho decisivo de la autoalienación significa "pobreza individual" pues ese individuo separado de sí necesita devenir integrado, en el mismo proceso por el cual se constituye en individuo universal integrado libre e solidariamente con los otros (en el seno de la comunidad comunista mundial). Esa situación puede ser reescrita usando categorías freudianas diciendo que esa "auto-alienación" indica la falta de consolidación del Yo en su (deseable) dominio del Ello y del Superyo; decía Freud que la tarea del psicoanálisis consiste en "fortalecer o Yo, hacerlo más independiente del Superyo, ampliar su campo de percepción y desarrollar su orga- nización, de manera que pueda apropiarse de nuevas partes del Ello; donde era Ello ha de ser Yo" (Freud 1968, vol. II, p. 916, "Nuevas aportaciones al psicoanálisis: la división de la personalidad psíquica").

Para terminar vale la pena recordar que para Marx el capitalista (aunque se beneficia de la alienación del trabajador) tampoco es un individuo humano realizado. En efecto (ecos hegelianos en Marx de la dialéctica del Amo y del esclavo) en su "función" de capitalista, no realiza su capacidad manual-productiva en interacción directa con la naturaleza no humana, y se hace esclavo del "tener", en un individualismo posesivo (III 147-150) que lo denuncia como un individuo que no está multilateralmente desarrollado. Por otro lado de nuestra parte evidenciamos también cuestiones racional-comunicativas que apuntaremos en lo que sigue.

\section{La crítica marxiana de la alienación en El capital}

6.1. Alienación en general y fetichismo; inversión sujeto-objeto y cosificación del ser humano

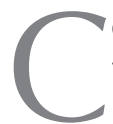

omo se sabe, en el primer volumen de El capital, en la sección dedicada al fetichismo de la mercancía (L. 1, S. 1, cap.1, ítem D4), Marx aclara que usa ese término para aludir al hecho de que así como el primitivo se hinca y adora al fetiche que él mismo creó con sus manos, admitiendo un poder de éste sobre él, el hombre que vive en las condiciones del capitalismo, se ve sometido al imperio de los resultados de sus relaciones sociales y de los frutos de su labor (en ese pasaje, en especial, las diversas mercancías que brotan del proceso productivo 
del trabajo social). Dice Marx: "El carácter misterioso de la forma mercancía estriba, por tanto, pura y simplemente, en que proyecta ante los hombres el carácter social del trabajo de éstos como si fuese un carácter material de los propios productos de su trabajo, un don natural social de estos objetos, como si, por tanto, la relación social que media entre los productores y el trabajo colectivo de la sociedad fuese una relación social establecida entre los mismos objetos, al margen de sus productores. Este quid pro quo es lo que convierte a los productos del trabajo en mercancía, en objetos físicamente metafísicos o en objetos sociales" (T. 1, S. 1, cap.1, p. 39). En esa dinámica, los seres humanos son objetivados y las que parecen tener relaciones sociales son las mercancías, en especial a través del valor (y su representante universal, el dinero): "La forma general del valor, forma que presenta los productos del trabajo como simples cristalizaciones del trabajo humano indistinto, demuestra por su propia estructura que es la expresión social del mundo de las mercancías" (T. 1, L 1, S. 1, cap.I, p. 35, el subrayado es mío). Y luego concluirá Marx, constatando-denunciando el atomismo-individualismo azuzado por el capitalismo: "La conducta puramente atomística de los hombres en su proceso social de producción, y por tanto, la forma material que revisten sus propias relaciones de producción, sustraídas a su control y a sus actos individuales conscientes, se revelan ante todo en el hecho de que los productos de su trabajo revisten, con carácter general, forma de mercancías. El enigma del fetiche dinero no es, por tanto, más que el enigma del fetiche mercancía, que cobra en el dinero una forma visible y fascinante" (T. 1, L. 1, S. 1, cap.2, p. 59). Esa fetichización del dinero alcanza su máxima expresión en el capital a interés, que reduce la fórmula general " $D-M-D^{\prime \prime}$ a sus dos extremos, "D - D" ${ }^{\prime \prime}$; dice Marx: "En el capital a interés aparece consumada la idea del capital-fetiche, la idea que atribuye al producto acumulado del trabajo plasmado como dinero, la virtud, nacida de una misteriosa cualidad innata, de crear automáticamente plusvalía en una progresión geométrica..." (T. 3, L. 3, S. 5, cap.XXIV, p. 419)

En esa fetichización general de la vida, ocurre la inversión sujetoobjeto y produce 'ideología' (en el sentido de una visión destorcida de la realidad que reposa en sus apariencias; Martínez Marzoa (en adelante, MM) relativiza la distorsión y enfatiza la apariencia, p. 105 y ss): "Por una parte, el trabajo pretérito que domina sobre el trabajo vivo, se personifica en el capitalista; por otra parte, el obrero aparece, a la inversa, como una fuerza de trabajo objetivada, como una simple mercancía. Y esta relación invertida hace surgir necesariamente, ya en el plano de las simples relaciones de producción, una idea invertida congruente, una consciencia transpuesta, que los cambios y modificaciones del verdadero proceso 
de circulación se encargan luego de desarrollar"(T. 3, L. 3, S. 1, cap. II, p. 67).

Como en el capitalismo, la fuerza de trabajo del obrero, los medios de producción, y los productos del trabajo (entre los que se incluyen medios de vida del trabajador) son capital, Marx afirma: "...el propio obrero produce constantemente la riqueza objetiva como capital, como una potencia extraña a él, que lo domina y lo explota, y el capitalista produce, no menos constantemente, la fuerza de trabajo como fuente subjetiva de riqueza, separada de sus propios medios de realización y materialización, como fuente abstracta que radica en la mera corporeidad del obrero, o, para decirlo brevemente, del obrero como obrero asalariado" (T. 1, L. 1, S. 7, cap.XXI, p. 517).

Previniendo contra la fetichización del 'capital', Marx alerta (contra la asunción ingenua de las categorías de la economía burguesa): "¡Capital, tierra y trabajo, muy bien! Pero el capital no es una cosa material, sino una determinada relación social de producción, correspondiente a una determinada formación histórica de la sociedad, que toma cuerpo en una cosa material y le infunde un carácter social específico" (T. 3, S. 7, cap.XLVIII, p.821).

Refiriéndose al proceso de cosificación y fetichización que ocurre en el capitalismo, dice AA: "...la alienación que las personifica (o, a la inversa, la personificación que las enajena) equivale a la so- $^{-}$ cialización de las cosas, pero a una socialización determinada. Si bajo todo régimen social de producción las cosas incorporan unos caracteres y cumplen unas funciones sociales, sólo un régimen como el capitalista les imprime universalmente una determinación que les confiere independencia y dominio sobre los individuos. La personificación de las cosas es, según eso, el modo específico de su socialización en el marco de la producción capitalista. Pues en este ámbito social, donde las cosas ejercen de mediadores y posibilitadotes reales de las relaciones entre los individuos, son ellas mismas las que deben asumir inmediatamente (y no mediatamente, como en otros modos de producción basados en relaciones más personales) las virtualidades sociales que las propias relaciones (asociales) entre los individuos en principio en principio rechazan. Las cosas resultan, así, en este régimen de producción sus verdaderos agentes socializadores, los personajes sociales" (p. 233). Y más adelante concluye AA: "La alienación de las cosas en este modo de personificación resulta ser, en consecuencia, una subjetivación de las cosas correlativa a una 'objetivación' de las relaciones sociales, o reificación), un proceso de inversión entre sujeto y objeto de la producción" (p. 235). Sólo nos resta recordar que en la evolución de su obra Marx reservó la categoría de "sociedad" y la de lo "social" (incluyendo las relaciones 
"sociales") para referirse a los vínculos interindividuales alienados en el capitalismo (a lo que contrapuso los vínculos "comunitarios" o la "libre asociación de los productores libremente asociados", en el poscapitalismo).

\subsection{Alienación de los medios de vida y producción}

Marx constata que en el capitalismo la situación de cada individuo viene predeterminada desde el nacimiento por la relación social existente entre los individuos englobados en dos grandes clases en lo que se refiere a la distribución de los medios de vida y de producción: una, que es propietaria de ellos (los capitalistas y terratenientes), y la otra que, desposeída de los mismos, no tiene más remedio que vender su fuerza de trabajo a los primeros para poder sobrevivir (los trabajadores). Esta situación constituye una flagrante violación de la libertad individual de decisión (en especial para los trabajadores) amparada por la primera norma de la ética y, por tanto, es subsumible críticamente por ella. En El capital esta distribución clasista asimétrica se desglosa en, por lo menos tres componentes: a) la tierra, b) las fábricas, máquinas, materias primas, $y, c)$ el dinero.

\subsubsection{Alienación de la tierra (priva- tización de la tierra)}

La tierra es, en principio, dadora de medios de vida y es un medio de producción; así, de ella podrían los seres humanos retirar in natura alimentos diversos (frutos, peces) y otros medios de vida (por ejemplo, madera para hacer muebles y calentarse), y, cultivándola, o sea usándola como medio de producción, podrían a través de la agricultura y la ganadería potenciar la cantidad y calidad de la satisfacción de sus necesidades vitales satisfechas por la tierra.

Pero ocurre que la tierra ha sido privatizada por una minoría (terratenientes que luego se alían, e incluso se funden con los capitalistas) separando a los trabajadores del acceso a la tierra. Así, dice Marx: "La propiedad territorial presupone el monopolio de ciertas personas que les da derecho a disponer sobre determinadas porciones del planeta como esferas privativas de su voluntad privada con exclusión de todos los demás" (T. 3, L. 3, S. 6, cap. XXXVII, p. 627). Esa situación es la base económica de la apropiación de la ganancia extraordinaria por parte del terrateniente que es al mismo tiempo capitalista explotador de 'su' tierra (a diferencia de lo que ocurre cuando recibe de manos del capitalista la renta derivada de la diferencia entre la ganancia media y la ganancia individual): "La propiedad territorial permite al propietario absorber la diferencia entre la ganancia individual y la ganancia media; la ganancia así captada, ganancia que se renueva todos los años, puede capitalizarse, presentándose como si fuese el precio de la misma fuerza natural" (de la tierra o de un salto de agua, etc.; T. 3, L. 3, S. 6, cap. XXXVIII, 
p. 658); y Marx dice "como si fue$\mathrm{se}^{\prime \prime}$ porque su tesis central es que la renta del terrateniente, como la ganancia del capitalista, son extraídas de la masas de plusvalía que la clase poseedora de los medios de vida y de producción arranca en su conjunto al conjunto de la clase trabajadora; aclaremos desde ya que nuestra subsunción ética de la crítica a la alienación es por completo independiente de la tesis crucial de Marx acerca de la plusvalía y todos sus derivados.

\subsubsection{Alienación de las fabricas (y máquinas, herramientas) y de las materias primas}

La alienación de los medios de vida y producción por el lado del trabajador queda patente como sigue: “...si el obrero pudiera dar a su trabajo una existencia independiente, vendería mercancía y no trabajo" (T. 1, L. 1, S. 6, cap.XVII, p. 482).

Globalmente, Marx ve así la situación: "El proceso capitalista de producción reproduce, por tanto, en virtud de su propio desarrollo, el divorcio entre la fuerza de trabajo y las condiciones de trabajo. Reproduce y eterniza, con ellos las condiciones de explotación del obrero. Le obliga constantemente a vender su fuerza de trabajo para poder vivir y permite constantemente al capitalista comprársela para enriquecerse" (T. 1, L. 1, S. 7, cap. XXI, p. 523). Y más adelante dice que el proceso productivo no asume la característica de acumulación de capital "mientras no se enfrentan con el obrero en forma de capital, sus medios de producción $y$, por consiguiente, su producto y sus medios de vida", T. 1, L. 1, S. VII, p. 543. Ante ello reacciona el obrero: "La faceta independiente y extraña que el régimen capitalista de producción presta a las condiciones y a los productos del trabajo respecto al obrero, enfrentándolas con éste, se convierte con la maquinaria, en una abierta y total contradicción. Por eso es en la era de la maquinaria cuando estallan las primeras revueltas brutales del obrero contra los instrumentos de trabajo" (T. 1, L. 1, S. 4, cap.XIII ítem 5, p. 383).

\subsubsection{Alienación del dinero trans- formado en modalidad de la rela- ción social de "capital"}

El dinero que deviene capital es el que se usa para comprar medios de producción y fuerza de trabajo con el propósito de producir plusvalía, de preferencia en reproducción ampliada, donde por lo menos una parte de la plusvalía es reinvertida sucesivamente en la compra de medios de producción y fuerza de trabajo a los efectos de generar más plusvalía. Ahora bien, ese dinero (como resultado de una acumulación originaria o como resultado del ciclo capitalista D-M-D') es propiedad del capitalista, y de él está alienado el trabajador (quien, precisamente por eso, se ve obligado a vender su fuerza de trabajo al capitalista). Dice Marx: "[en el capitalismo] sólo existen dos clases: la clase obrera, que no dispone más que de su fuerza de trabajo, y la 
clase capitalista, monopolizadora tanto de los medios de producción como de dinero" (T. 2, L. 2, S. 3, cap.XX ítem V, p. 399).

Resumiendo la situación general de los medios de producción, Marx afirma: "La forma de las condiciones de trabajo alienada de éste, autónoma frente a él, y, por tanto, transfigurada, en que los medios de producción creados se convierten en capital y la tierra en tierra monopolizada, en propiedad territorial, esta forma correspondiente a un determinado período histórico, coincide, por consiguiente, con la existencia y la función de los medios de producción creados y de la tierra en el proceso de producción en general" (T. 3, L. 3, S. 7, cap. XLVIII, p. 831-832).

Como alternativa poscapitalista, Marx plantea la hipótesis (que hacemos nuestra) de una organización comunitaria donde la tierra y demás medios de producción devengan propiedad social de los productores libres y libremente asociados, para satisfacer las necesidades de cada uno (sin devastar la naturaleza no humana).

\subsection{Alienación del trabajo}

El trabajador está obligado (negación de la primera norma de la ética) a vender su fuerza de trabajo a los capitalistas dueños de los medios de producción para poder sobrevivir. Ahora bien, para que esa venta se haga efectiva, no basta la voluntad del trabajador, pues depende de la voluntad del capi- talista de contratarlo; así el desempleo acecha siempre al trabajador, como una dura realidad presente y/o siempre como una amenaza futura que se puede concretar a cualquier momento. Dice Marx: "La inseguridad e irregularidad del trabajo, la frecuente repetición y larga duración de sus interrupciones, síntomas todos de la existencia de una superpoblación relativa, figuran en los informe de los inspectores de beneficencia como otras tantas quejas del proletariado agrícola irlandés" (T. 1, L. 1, S. 7, cap. XXIII ítem $5 f$, p. 649). Además hay que considerar las largas consideraciones de Marx sobre la superpoblación relativa y el ejército industrial de reserva, umbilicalmente unidas a la inestabilidad del acceso al trabajo y a la amenaza-realidad del desempleo (en T. 1. L. 1, S. 7, cap.XIII ítem 3 y 4, p. 573-591). La amenaza del desempleo se acentúa para el trabajador con la concentración de capitales y la progresiva predominancia del capital constante (medios de producción) sobre el capital variable (salarios); en efecto: "...la concentración amplía y acelera al mismo tiempo las transformaciones operadas en la composición técnica del capital, permitiendo aumentar el capital constante a costa del variable, y reduciendo, como es lógico, la demanda relativa de trabajo" (T. 1, L. 1, S. 7, cap. XXIII, p. 573). Y lo tragicómico es que es el propio obrero quien produce su desempleo: "Por tanto, al producir la acumulación del capital, la población obrera produce también, 
en proporciones cada vez mayores, los medios para su propio exceso relativo" (ídem. p. 575). Ahora bien, como ese exceso relativo (que configura el "ejército industrial de reserva" del que echa mano el capitalista cuando el conviene) permite que el capitalista se aproveche de la incrementada lucha entre los obreros par conquistar un trabajo, para reducir los salarios, dirá Marx (oponiéndose a Malthus): "La superpoblación relativa [de obreros] es, por tanto, el fondo sobre el cual se mueve la ley de la oferta y la demanda de trabajo. Gracias a ella, el radio de acción de esta ley se encierra dentro de los límites que convienen en absoluto a la codicia y al despotismo del capital" (ídem. p. 583; hay que recordar que Marx dedica los ítems ' 3 ' y '4' del cap. XXIII del T. 1 de El capital a la discusión de la ley de superpoblación relativa en el capitalismo, p. 573 a 591).

Esta alienación del trabajador en relación al trabajo viola la primera norma de la ética, porque le es retirada al trabajador la libertad de trabajar o no y de decidir cuándo, cómo y cuánto lo hará.

Ángel Prior Olmos (abreviado $\mathrm{PO}$ en lo que sigue) destaca que "Marx subraya el carácter ilusorio de las relaciones de intercambio como relaciones de individuos presuntamente libres. Los individuos se relacionan mutuamente como individuos en una determinación dada. En las relaciones propias de un sistema de intercambio... burgués...Marx resalta cómo el trabajador se ve obligado a vender su fuerza de trabajo para poder vivir... [y] la cuestión de por qué ese trabajador libre le sale al encuentro en la esfera de la circulación, no le interesa al poseedor del dinero" (PO, p. 64). A la luz de esos hechos y burlándose de la falsa libertad capitalista-burguesa y de las teorías filosófico-jurídicas que la defienden, Marx dirá en El capital: "Lo único que impera allí es libertad (Freiheit), igualdad (Gleichheit), propiedad (Eigentum), y Bentham. ¡Libertad! Pues el comprador y el vendedor de una mercancía, por ejemplo la fuerza de trabajo, no están determinados más que por su libre voluntad (freien willen). Contratan como personas libres, jurídicamente iguales. EI contrato es el resultado final en el que sus voluntades se dan expresión jurídica común" (citado por PO, p. 65). Marx sostendrá, al contrario, en El capital, que cuanto más se desarrolla el capitalismo, más precaria es la garantía del trabajo (y con ello la subsistencia) del trabajador: "Cuanto más elevada es la fuerza productiva del trabajo", tanto mayor es la presión sobre los medios de ocupación del trabajador..."o sea, tanto más precaria es su condición de existencia: la venta de su propia fuerza para aumentar la riqueza ajena, para la autovaloración del capital" (citado por PO, p. 145).

Por su parte, MM ha notado que en el capitalismo la objetividad tiene por fundamento "la alienidad de la medida de trabajo con respecto al trabajo 'real' mismo", pues las 
mercancías (cosas) son expresión de cantidades de trabajo, y "términos en una universal relación de cambio" (p. 111).

En virtud de la alienación respecto al trabajo se hace posible el desempleo, que, a su vez, puede desembocar en la mendicidad, transformando al trabajador en un trapero. Al respecto dice Reyes Mate, haciéndose el eco de Walter Benjamin: "El trapero...dispone de un punto de vista privilegiado para analizar las sociedades avanzadas. Al trapero no se le oculta que el sistema funciona creando desechos que luego recicla y aprovecha como alimento de la maquinaria". Y agrega: "La sombras son una realidad del sistema y también la metáfora de la exclusión. Lo que el sistema desecha no es sólo lo que circula por las cloacas o va al cubo de las basuras. Convierte en basura todo lo que usa y que un momento antes ha sido festejado con todos los honores" (Reyes Mate, 2009). A la luz de esa situación analizamos la reflexión tejida por Reyes Mate para otro contexto, cuando registrando el hecho cultural actual de que le ha llegado el fin a la invisibilidad de las víctimas (que yo interpreto aquí como víctimas del sistema capitalista, en las que, por cierto y como se verá más adelante, hay que incluir al propio capitalista), manifiesta: "El asesinato no puede tomarse como una fatalidad del destino o como un paso lógico del progreso. Las víctimas se han hecho visibles. Han dejado de ser el precio silencioso de la política y de la historia. La visibilidad consiste en haber logrado que su sufrimiento deje de ser insignificante, es decir, que signifique injusticia" (Reyes Mate, 2008, p. 21).

\subsection{Alienación del producto del trabajo}

El trabajador no puede usar para satisfacer sus necesidades aquellos productos que son fruto de su producción y/o de la producción de otros trabajadores. Tiene que contentarse con el salario, que paga el valor de su fuerza de trabajo, y sólo entonces en calidad de "consumidor" intentará reencontrarse en el mercado (dentro del límite de la capacidad adquisitiva del monto de su salario) con los frutos de su trabajo y el de los otros productores. Rastreando la exacerbación de la separación del productor en relación a los productos por él creados, en la adopción del maquinismo, dice Marx: "La faceta independiente y extraña que el régimen capitalista de producción da a las condiciones y a los productos del trabajo respecto al obrero, enfrentándolos con éste, se convierte, con la maquinaria, en una abierta y total contradicción" (T. 1, L. 1, S. 4, cap.XIII, p. 383, el subrayado es mío). Exponiendo la realidad de la propiedad en el embolso por el capitalista de la plusvalía arrancada al obrero (que antes de su realización en dinero se expresa en una determinada cantidad del producto producido por aquél), dice nuestro autor: "Ahora la propiedad, vista del lado del capitalista, se convierte 
en el derecho a apropiarse trabajo ajeno no retribuido, o su producto, y, vista del lado del obrero, como la imposibilidad de hacer suyo el producto de su trabajo" (T. 1, L. 1, S. 7, cap. XXII, p. 529, los subrayados son míos).

Y luego aclara: "Como antes de entrar en el proceso de producción el obrero es despojado de su propio trabajo, que el capitalista se apropia e incorpora al capital, durante el proceso este trabajo se materializa constantemente en productos ajenos. Y como el proceso de producción es, al mismo tiempo, proceso de consumo de la fuerza de trabajo por el capitalista que la adquiere, el producto del obrero no sólo se transforma constantemente en mercancía, sino también en capital" (T. 1, L. 1, S. 7, cap. XXI, p. 516).

Esta situación viola las dos primeras normas de la ética pues no son los productores quienes a partir de su libertad de opinión y en dinámica consensual resuelven sobre la distribución del fruto del trabajo social, sino que se ven limitados en sus elecciones no consensuales a lo que dispone la capacidad adquisitiva limitada de sus salarios respectivos. Por otro lado, esa insuficiencia muchas veces deriva en una violación de la tercera norma de la ética, que ocurre cuando la salud del trabajador se ve afectada por la incapacidad de satisfacer ciertas necesidades (materiales o espirituales, diría Marx). Añade el autor: "El capital variable no es, pues, ..., más que una forma histórica concreta de manifestarse el fondo de medios de vida o el fondo de trabajo de que necesita el obrero para su sustento y reproducción y que en todos los sistemas de producción social tiene constantemente que producir y reproducir. Si el fondo de trabajo afluye a él constantemente en forma de medios de pago de su trabajo, es, sencillamente, porque su propio producto se aleja de él en forma de capital" (T. 1, L. 1, S. 7, cap. XXI, p. 514; ver también ítems 3 y 4 , y T. 2, L. 2, S. 3, cap.XIX, ítem II5, y T. 3, L. 3, S. 6, al fin del cap. XLVII e inicio del XLVIII).

PO recuerda como en El capital, Marx "destaca lo enigmático que se torna la forma de la mercancía para la conciencia de los hombres", al punto de que para explicar ese hecho a través de "una analogía adecuada, hay que recurrir a la región nebulosa del mundo religioso. En este los productos de las cabezas humanas aparecen entre ellas y los hombres. Así les ocurre en el mundo de mercancías a los productos de la mano humana" (citado por PO, p. 140). Y Marx aclarará después en El capital: "Lo enigmático de la forma mercancía consiste, pues, simplemente en que devuelve a los hombres la imagen de los caracteres sociales de su propio trabajo deformados como caracteres materiales de los productos mismos del trabajo, como propiedades naturales sociales de esas cosas; y por lo tanto, reflejan también deformadamente la relación social de los productos con el trabajo total, en 
forma de una relación entre objetos que existiera fuera de ellos" (citado por PO, p. 155).

\subsubsection{Alienación del mercado}

Es de notar la característica alienada de ese mercado en el que el productor intenta satisfacer sus necesidades vistiendo la piel del "consumidor": "El mercado tiene, por tanto, que extenderse constantemente, de modo que sus conexiones y las condiciones que lo regulan van adquiriendo cada vez más la forma de una ley natural independiente de la voluntad de los productores, cada vez más incontrolable" (T. 3, L. 3, S. 3, cap. XV, ítem 1, p. 267).

Esas consideraciones cobran actualidad redoblada cuando la TV no cesa de decir, un día sí y el otro también, que "el mercado está nervioso", o "el mercado está animado", o "el mercado espera tal medida del gobierno", y otras tantas joyas que personifican al mercado y ponen a los individuos de carne y hueso a su merced. Tal situación viola flagrantemente la libertad de decidir y la exigencia de hacerlo consensualmente, estipuladas por las dos primeras normas de la ética, y como vimos, también es violada la tercera norma cuando la salud del trabajador es afectada por esa alienación, y/o es afectada la salud de la naturaleza no humana (por ejemplo por las contaminaciones generadas por los desechos del consumo gobernado sin ningún plan por el 'mercado').

\subsection{Alienación de la actividad productiva}

Cuando el trabajador tiene la "suerte" de poder vender su fuerza de trabajo a un capitalista para poder sobrevivir, su actividad productiva deja de pertenecerle. Dice Marx: "Lo que éste [el trabajador] vende es su fuerza de trabajo. Tan pronto como su trabajo comienza a ponerse en acción, ha dejado de pertenecerle a él, y no puede, por tanto, vender lo que ya no le pertenece" (T. 1, L. 1, S. 5, cap.XXII, p. 484)

Esta alienación es una flagrante violación de la libertad de decisión amparada por la primera norma de la ética, y entraña plausibles violaciones de la tercera norma (como sucede cuando el empleo a destajo de su fuerza de trabajo deriva en enfermedades profesionales, como los son, las "lesiones por esfuerzo repetitivo", LER, o DORT, "enfermedades osteomusculares" relativas al trabajo, flagelos de la actualidad); al mismo tiempo, al serle retirado el control de su actividad, el trabajador no puede velar, como lo exige también la tercera norma, por la salud de la naturaleza no humana que puede ser afectada (por contaminación y devastación, en especial) por esa actividad productiva y sus efectos, que él no controla.

Otra dimensión de esa alienación lo constituye el hecho de que la actividad productiva del trabajador es gobernada despóticamente por las órdenes del capitalista y sus 
representantes, en clara violación de la dinámica consensual de construcción de decisiones, estipulada por la segunda norma de la ética. Ambas dimensiones fueron cuestionadas de manera brillante por Charles Chaplin en Tiempos modernos.

Dice Marx, refiriéndose al trabajador: "Tan pronto como su trabajo comienza a ponerse en acción, ha dejado de pertenecerle a él y no puede, por tanto, vender lo que ya no le pertenece" (T. 1, L. 1, S. 6, cap.XVII, p. 484); y antes, incluyendo la disciplina de las órdenes en esa dimensión de la alienación, Marx había dicho: "El trabajador trabaja bajo el control del capitalista, a quien su trabajo pertenece. El capitalista se cuida de vigilar que ese trabajo sea ejecutado como es debido y que los medios de producción sean empleados convenientemente..." (T. 1, L. 1I, S. 3, cap. V, p.147).

Mas no ha de olvidarse que, en El capital, Marx (usando una imagen de clara inspiración platónica) continúa marcando claramente la diferencia entre la actividad productiva humana y cualquier acción animal: "Pero en lo que ya por anticipado distingue al peor arquitecto de la abeja mejor es que el arquitecto construye la celdilla en su cabeza antes de construirla con cera...No es sólo que el trabajador obre una alteración de forma de la naturaleza; es que al mismo tiempo realiza en lo natural su finalidad (Zweck), la cual es conocida por él, y determina como ley el modo de su hacer y tiene subordinada su voluntad" (citado por PO, p. 98). Y también en El capital (T. I, cap. V), Marx vuelve a destacar que "El trabajo es, por de pronto, un proceso entre ser humano (Mensch) y naturaleza (Natur), un proceso en el cual el ser humano media, regula y controla mediante su propia actividad su metabolismo con la naturaleza. El ser humano se enfrenta con la materia natural como fuerza natural él mismo. Pone en movimiento las fuerzas naturales pertenecientes a su corporeidad — brazos y piernas, cabeza y mano- con objeto de apropiarse la materia natural de una forma utilizable para su propia vida. Mediante ese movimiento obra en la naturaleza externa a él y la altera, y así altera al mismo tiempo su propia naturaleza. Desarrolla las potencias que dormían en ella y somete a su propio dominio el funcionamiento de sus fuerzas" (citado por PO, p. 112).

\subsection{Alienación del otro ser humano}

El capitalismo es esa guerra de todos contra todos, en la que los capitalistas se oponen a los trabajadores y viceversa, al tiempo en que los capitalistas y los trabajadores se oponen, por su lado y respectivamente, entre sí. Esa guerra es claramente violatoria de las tres normas (incluyendo a la tercera por las enfermedades físicas o nerviosas que pueden derivar de ese conflicto incesante). Basta oír la radio para saber que en cada huelga capitalistas y trabajadores se oponen en 
especial por el monto del salario, la duración de la jornada de trabajo y las condiciones en las que se realiza el mismo (que pueden ser más o menos penosas para el trabajador); y en perspectiva histórica, ambos se oponen objetivamente por la propiedad de los medios de producción (que en el capitalismo pertenecen a los capitalistas, y que la revolución comunista pretende colocar en manos de los productores libremente asociados). A su vez, los trabajadores de oponen entre sí, en especial a causa de la lucha para acceder y permanecer en un empleo remunerado con un salario. Y también se oponen los capitalistas, en especial en la competencia por la conquista y manutención de mercados y por la obtención de créditos, ambas situaciones vitales para su manutención como capitalistas, o su muerte como tal en la lid de la competencia con sus pares.

\subsubsection{El obrero opuesto al capita- lista y al obrero}

Explicando la manera en que se constituye una cuota general de ganancia, observa Marx que se nivelen ciertos desniveles en la plusvalía y/o la ganancia, y que: "Esto presupone la concurrencia entre los obreros y la nivelación mediante su emigración constante de una rama de producción a otras"(T. 3, L. 3, S. 2, cap X, p. 197).

\subsubsection{El capitalista opuesto al obrero y al capitalista}

Abordando otra faceta de la oposición entre capitalistas, señala
Marx que cuando se trata, no de distribuir ganancias, sino pérdidas, entonces, "esto lo decide la fuerza y la astucia; al llegar aquí la concurrencia se convierte en una lucha entre hermanos enemigos. A partir de este momento se impone el antagonismo entre el interés de cada capitalista individual y el de la clase capitalista en su conjunto, del mismo modo que antes la identidad de esos intereses se abría paso prácticamente a través de la concurrencia" (T. 3, L. 3, S. 3, cap. $\mathrm{XV}$, p. 275).

\subsubsection{El campesino opuesto al campesino}

La mutua alienación tampoco excluye a los campesinos. Dice Marx, al referirse a la formación de una clase de jornaleros agrícolas desposeídos de medios de producción: "En el período de formación de esta nueva clase, que sólo existe todavía en estado esporádico, los campesinos acomodados tomaron la costumbre de explotar por su cuenta a jornaleros agrícolas, del mismo modo que en la época feudal los villanos afortunados tenían a su servicio a otros vasallos" (T. 3, L. 3, S. 6, cap. XLVII ítem 4, p. 806).

Nota AA al abordar la alienación de los individuos entre sí, que ocurre en el capitalismo, que "La alienación de los individuos significa, más bien, la autonomía, sustantivación y dominio de unos individuos frente a otros en virtud de su forma social". Y explica: "En el modo de producción capitalista 
la forma social del individuo le viene impresa por estas relaciones sociales específicas que en él, como en cualesquiera entes materiales, toman cuerpo y le convierten en sus personificaciones. La forma social del individuo es, por consiguiente, su ser social como personificación de aquellas relaciones" (p. 239). También AA subraya que habrá dos "grandes modos de personificación", el del capitalista y el del asalariado, en la medida en que ambos "actúan como funcionarios del capital". Y aclara: "Pero mientras el capitalista será capital personificado, por ser la personificación de los medios de producción, el obrero será trabajo vivo o tiempo de trabajo personificado en su calidad de representante de la fuerza de trabajo, tal como Marx lo repite hasta la hartura. Y así la personificación se ha dividido en una personificación específica como poder y en otra personificación como sumisión" (p. 241). Y AA concluye: "El poder del capitalista, en definitiva, revela así la naturaleza última del poder en la sociedad moderna y el carácter formal y delegado (subsidiario) desde el capital de todos los demás poderes sociales" (p. 247), y "Al resumir este poder -esta separación, autonomía y dominio de uno individuos respecto de otros en virtud de su determinación social- como enajenación de los individuos, nótese que es justamente esta alienación la que da lugar a las clases sociales específicas del régimen capitalista" (p. 249).

\subsection{Alienación de sí mismo}

Estas múltiples facetas de la alienación entrañan que en el capitalismo (especialmente el trabajador, pero también el capitalista), el ser humano se encuentra alienado con respecto a sí mismo, una vez que el individuo se estructura a partir de ese "nudo" que es de relaciones sociales, y de las que existen en el capitalismo con la naturaleza no humana, mediadas por las primeras. Tal situación es claramente violatoria de la libertad de decisión exigida por la primera norma de la ética.

Para el trabajador eso se muestra, por ejemplo, en el hecho de que se relaciona con los otros trabajadores "como individuos" (subraya Marx), sólo cuando entran en relación con el mismo capital, pero no entre sí, y "Su cooperación comienza en el proceso de trabajo, es decir, cuando ya han dejado de pertenecerse a sí mismos" (el énfasis es mío, T. 1, L. 1, S. 4, cap. XI, p. 288). Esa alienación en 'el capital' se expresa así: "En la manufactura, lo mismo que en la cooperación simple, la individualidad física del obrero en funciones es una forma de existencia del capital" (T. 1, L. 1, S. 4, cap. XII ítem 5, p. 315); y luego dirá Marx: "...en el sistema basado en la maquinaria, la gran industria posee un organismo perfectamente objetivo de producción con que el obrero se encuentra como una condición material de producción lista y acabada" (T. 1, L. 1, S. 4, cap. XIII ítem 2, p. 338), 
y antes había comentado el impacto de esa situación sobre la subjetividad como sigue: "En la producción a base de maquinaria desaparece el principio subjetivo de división del trabajo. Aquí el proceso total se convierte en objetivo..." (ídem., p. 332).

Nota AA que "el ser autoenajenado de la materia consiste ante todo en un ser-de-otro-modo (Anderssein) (AA, p. 253), y resume su visión en este punto como sigue: en el capitalismo "...es tal el sometimiento de los caracteres materiales de los individuos y de las cosas a los imperativos sociales de aquella forma, tal la pérdida y vaciamiento de las propiedades humanas y objetivas, que en último término, los individuos tienden a desaparecer como sujetos personales y las cosas a ver esfumadas sus propiedades específicas; y que en resumen, la realidad entera ofrece un inmenso espectáculo en el que el lugar de unos y otras ha sido ocupado por formas y funciones sociales capitalistas en ellos sustantivadas, únicas protagonistas del proceso social y representadas bajo figura de cosas e individuos" (p. 258).

Citando las palabras del Marx en el tercer tomo de El capital [Los agentes principales de este sistema de producción, el capitalista y el obrero asalariado, no son, como tales, más que encarnaciones, personificaciones del capital y el trabajo asalariado, determinados caracteres sociales que el proceso social de producción imprime en los indivi- duos; productos de estas determinaciones sociales de producción"] AA observa que en el capitalismo "La determinación formal de los individuos, en definitiva, consiste en el ser o carácter social que reciben como personificación de aquellas relaciones sociales a través de la personificación de sus capacidades (separadas de sí mismo) y de sus objetos" (p. 273). Mas observa AA que la forma social capitalista resulta también positiva para el individuo, pues "la forma capitalista de los factores productivos, al obligar a la producción a un crecimiento imparable en extensión e intensidad, promueve el desarrollo hasta ahora inigualado de la naturaleza humana" (p. 275). Si compartimos la idea de que el individuo capitalista es un momento aparentemente necesario del proceso de expansión del individuo universal del poscapitalismo, hay que hacerle hoy a AA la acotación (apoyada en la tercera norma de la ética y en la evidente crisis ecológica mundial) de que ese "crecimiento imparable" de la producción se hace a costa de los grandes equilibrios ecológicos (y que el paso al poscapitalismo, como lo intuyó Benjamin, es por lo menos al mismo tiempo que un salto adelante en el proceso de individuación, un "freno" puesto a la locomotora desgobernada del capital que amenaza conducir al holocausto de la humanidad y de buena parte del planeta). En todo caso, queda hoy más claro que nunca que la apuesta a la emergencia del individuo universal se hace 
desde "la alienación prácticamente universal de los individuos bajo las relaciones capitalistas avanzadas" (AA, p. 279).

Dice AA que donde mejor se trasluce el grado de autoalienación del individuo (aunque a nuestro juicio también podemos incluirla en la alienación interindividual) es en la ley de población propia al modo capitalista de producción, pues ella hace aparecer una superpoblación "excedente, sobrante, remanente, un conjunto de individuos sin derecho a la vida en razón de la forma social que las relaciones capitalistas imprimen a sus condiciones materiales de existencia" (AA, p. 284), superpoblación ésta que, como dijo Marx, constituye un ejército industrial de reserva, al servicio del capital (incluso para usarlo como medio de presión para rebajar los salarios), cuando lo entienda útil y necesario. Y AA destaca que en su autoenajenación capitalista "Ios individuos resultan idénticos, tan intercambiables entre sí como sus mercancías, abstractos, carentes de toda peculiaridad diferenciadora, perfectamente sustituibles, equivalentes, indiferentes entre sí por ser realmente in-diferentes" (AA, $p$. 288). Basta una ojeada a la moda en el vestir y en las costumbres, al recambio de empleados por otros que se permite a cualquier momento cualquier empresa, y a la mutua indiferencia entre los que habitan en las grandes urbes, para certificar el aserto de esa observación.
Por su parte PO destaca como en El capital la concepción marciana "se opone a los intentos de concebir una naturaleza humana inamovible, fija de una vez por todas, frecuente, entre otros, en los pensadores del siglo XVIII" Y cita un pasaje $\mathrm{d} E \mathrm{I}$ capital en el que Marx apunta la deuda de Bentham para con Helvetius: "El principio de la utilidad no era invento de Bentham. Reproducía sólo sin gracia lo que habían hecho con ella Helvetius y otros franceses del siglo XVIII. Cuando se quiere saber, por ejemplo, qué es útil para un perro, hay que investigar la naturaleza perruna. Esta naturaleza misma no se puede construir sobre la base del 'principio utilitarista'. Aplicado al ser humano: si se quiere juzgar de acuerdo con el principio de utilidad de toda acción, todo movimiento, toda relación o situación, etc., humanos, se tratará, primero de la naturaleza humana en general, y luego de la naturaleza humana históricamente modificada" (citado por O, p. 93-94). Por mi parte aquí me permito sólo indicar la importancia del hecho de que Marx, defensor de la construcción histórico-social incesante del ser humano, no reniegue de ciertas 'invariantes humanas' (al referirse a la 'naturaleza humana en general'), cuestión que es decisiva (en especial por su connotación ecológica, vinculada a la tercera norma de la ética) para discutir las "necesidades humanas". 
AA hace un claro recuento, que transcribimos integralmente, de cómo se cumplen en el capitalismo, y en especial para el obrero, "todos los requisitos de la alienación"; dice: "La cosa-fuerza de trabajo, en su determinación social de mercancía o en tanto que soporte del capital variable, alcanza los caracteres de autonomía, sustantivación y poder sobre los individuos que la albergan. Como en el caso de cualquier otro objeto depositario de la forma social capitalista, la vida y el movimiento de los individuos depende enteramente de la vida y movimiento insuflado en este singular objeto, al fuerza de trabajo. La independencia de su propia capacidad laboral respecto del trabajador es tan palpable como la del objeto y los medios de producción cuando reciben su carácter social de capital constante: de hecho es, como éstos, una propiedad ajena, propiedad del capital que la adquiere; y el dominio sobre el sujeto que a encarna, tan férreo como el de los elementos materiales del trabajo. Si la fuerza de trabajo es, en el proceso de producción capitalista en tanto que proceso de valorización, un medio de los medios de producción, el individuo trabajador se convierte a su vez en un medio de su fuerza de

trabajo, en su propiedad efectiva. Su ser como individuo está en función de su ser como trabajador (propietario de la capacidad laboral), su destino individual está fijado por este objeto específico, su vida ha de empezar por ponerse al servicio de su capacidad de trabajo. A fin de cuentas, su existencia física misma pende por entero de la venta de este objeto y de él recibe se permiso de vivir (p. 222).

\section{El punto de vista de Prior Olmos}

$\mathrm{PO}$ recuerda como algunos autores han contrapuesto la crítica a la alienación, como supuesta expresión exclusiva de la obra del joven Marx, o incluso como creación de Lukács en Historia y conciencia de clase, a la teoría del valor-trabajo y de la plusvalía (que sería la propia del Marx maduro, en especial en $E I$ capital). PO por su parte, ve, "por el contrario, el ensayo de Lukács sobre la reificación publicado en dicha obra [como] un argumento adicional para afirmar la unidad del pensamiento de Marx. El hecho de que Lukács pudiera reconstruir en sus rasgos más profundos la teoría de la alienación de Marx, basándose en El capital y la Contribución de 1859, prueba la profunda relación entre el Marx joven y su obra de madurez" (PO, p. 153). Hacemos nuestra esta lectura de PO. 


\section{Marx y la cuestión de la libertad y la autonomía}

- n su estudio dedicado a El capital, García de Haro (García 1987), desde una militancia católica muy explícita, declara a Marx un enemigo de la libertad. Dice "Toda la teoría del régimen capitalista de producción [en El capital] es -lo acabamos de ver - una continua negación de la posibilidad misma de la libertad". Y agrega: "Es sintomático que Marx, en los tres extensos volúmenes de El capital, sólo dos veces trate de la libertad. La primera para decir que lo que creen tal los capitalistas y se defiende en la sociedad burguesa, no existe; es una mera apariencia (Tomo I)...La segunda, para dibujar en qué consistiría la libertad en el futuro régimen comunista (Tomo III)" (p. 109-110). Nuestro autor resume su postura sobre la posición de Marx acerca de la libertad en El capital, como sigue: 1) En Marx, la libertad deja de ser reconocida como propiedad esencial de la persona. Es más bien algo que le advienen extrínsecamente: de un modo semejante a como se habla de libertad para las bestias, que se dicen libres si no están enjauladas. Ha dejado de entenderse como propiedad de la naturaleza humana, inseparable de la dignidad personal, que nadie puede arrebatar al hombre, y a cuyo íntimo ejercicio sólo él puede renunciar. Para Marx el hombre nunca posee por sí la libertad; aun en la futura perfección del paraíso comunista, nunca será libre mientras trabaje. La producción como necesidad que la elimina, lo seguirá siendo en esa etapa: mientras trabaje permanecerá en el reino de la necesidad. Sólo fuera de la jornada de trabajo cabe la libertad: en el mejor de los casos el hombre es libre a ratos... 2) Coetánea con al pérdida de la noción de libertad como propiedad de la persona es la disolución de la distinción entre bien y mal, sustituida por la categoría suprema del 'progreso. La perfección del hombre no es algo personal, fruto del buen ejercicio de la libertad, sino un desarrollo necesario del incesante desarrollo histórico...3) Por último, hay en Marx un Ilamativo odio hacia el arrepentimiento cristiano, que termina de delimitar lo radical de su negación de la libertad: si no hubiera libertad, puro hacer y obrar bien se identificarían; el bien sería el escueto ejercicio del propio poder de obrar y el único mal arrepentirse de los propios actos...(p. 113 -118).

Y García explicitará su credo al detallar en el cuarto-último capítulo de su obra, respectivamente, 'La esencia de la tentación marxista', 'La posibilidad de renunciar al bien honesto', y la 'Urgencia de recordar cuál es el verdadero bien común de la sociedad', que, por supuesto, ya estaría definido por a doctrina de la Iglesia católica. 
Es evidente que nuestro autor no percibió que en El capital la alusión (directa o indirecta) a la libertad, va mucho más allá de la dos veces registradas por él. Lo que García de Haro no vio o no quiso ver es que en El capital Marx muestra cómo y por qué la libertad humana es imposible en el capitalismo. Por su parte, PO sostiene, refiriéndose a Marx, que "la temática de la libertad ocupa un papel de suma relevancia para la comprensión de su obra, pues recorre el conjunto de la producción literaria de Marx, desde su Disertación de Doctorado hasta los últimos capítulos del libro III de El capital, constituyéndose en el motivo central que subyace a diversos conceptos básicos de su operar teórico, como pueden serlo la temática de la emancipación humana, social y política, la teoría de la alienación y el fetichismo de la mercancía, el papel del proletariado como clase llamada a liberarse y la anticipación del comunismo como estadio del decurso histórico que posibilite nuevas relaciones humanas" (PO, p. 43).

Basándonos en las exigencias de la dos primeras normas fundamentales de la ética (luchar por la libertad individual de decidir, y, ejercerla buscando decisiones consensuales), queremos enfocar ahora con más detenimiento y en óptica diametralmente opuesta a la de García de Haro y similar a la de PO, las posiciones crítico-propositivas de Marx en relación a la libertad y la autonomía.
En los Manuscritos de 1844, aún en plena crítica de la filosofía hegeliana (que ocupa la última parte del tercer Manuscrito), Marx denuncia la dependencia del trabajador en el contexto del modo de producción capitalista, considerándola (a veces implícitamente) como una restricción inaceptable de su autonomía (decisoria). Así, entre otros pasajes, leemos: "Un ser sólo se considera independiente en cuanto es dueño de sí y sólo es dueño de sí en cuanto se debe a sí mismo su existencia. Un hombre que vive por gracia de otro se considera a sí mismo un ser dependiente" (III 154); ahora bien, como el trabajador, alienado de los medios de vida y de producción, debe su existencia al salario que le paga el capitalista, se hace de él dependiente, más aún, esclavo: "...el alza de los salarios conduce a un exceso de trabajo de los obreros. Cuanto más quieren ganar, tanto más de su tiempo deben sacrificar $y$, alienándose de toda libertad, han de realizar, en aras de la codicia, un trabajo de esclavos"; y completa poco después: "Y así [el obrero]...se va haciendo cada vez más dependiente de todas las fluctuaciones del precio de mercado, del empleo de los capitales y del humor de los ricos" (I 54). Más adelante, machaca: "Un alza forzada de los salarios, prescindiendo de todas las demás dificultades... no sería...más que una mejor remuneración de los esclavos, y no conquistaría, ni para el trabajador, ni para el trabajo, su vocación y su 
dignidad humanas" (I 117). Completando la idea con la otra cara de la moneda, dice: "La concentración de capitales se hace mayor, los capitalistas grandes arruinan a los pequeños y una fracción de los antiguos capitalistas se hunde en la clase de los obreros, que por obra de esta aportación padece de nuevo la depresión del salario y cae en una dependencia aún mayor de los pocos grandes capitalistas" (I 55). Y remata: "En tanto que el trabajo suscita la acumulación de capitales y con ello el creciente bienestar de la sociedad, hace al obrero cada vez más dependiente del capitalista..." (I 57). Fiel a su estilo de reconocer deudas y precursores, Marx cita la misma idea formulada por Pecqueur en Théorie nouvelle $d^{\prime}$ économie sociale: "Pour vivre, donc, les nonpropriétaires sont obligés de se mettre, directement ou indirectement, au service des propriétaires, c'est à dire sous leur dépendance" (p. 409, I 63; Para vivir, los no propietarios están obligados a ponerse directa o indirectamente al servicio de los propietarios, o sea bajo su dependencia).

En El capital, haciendo el balance entre liberación y sojuzgamiento provocado por la aparición del capitalismo, dice Marx: "El productor directo, el obrero, no pudo disponer de su persona hasta que no dejó de vivir sujeto a la gleba y de ser esclavo o siervo de otra persona. Además, para poder convertirse en vendedor libre de su fuerza de trabajo, que acude con su mercan- cía a dondequiera que encuentra mercado para ella, hubo de sacudir también el yugo de los gremios, sustraerse a las ordenanzas sobre los aprendices y los oficiales y a todos los estatutos que embarazaban el trabajo. Por eso, en uno de sus aspectos, el movimiento histórico que convierte a los productores en obreros asalariados representa la liberación de la servidumbre y la coacción gremial, y este aspecto es el único que existe para nuestros historiadores burgueses. Pero, si enfocamos el otro aspecto, vemos que estos trabajadores recién emancipados sólo pueden convertirse en vendedores de sí mismos, una vez que se ven despojados de todos sus medios de producción y de todas las garantías de vida que las viejas instituciones les aseguraban. El recuerdo de esta cruzada de expropiación ha quedado inscrito en los anales de la historia con trazos indelebles de sangre y fuego" (T. 1, L. 1, S. 7, cap. XXIV, p. 655-656). Y, retomando el tema de la (in)dependencia con palabras muy similares a las de 1844, dirá Marx: "Y nuestros poseedores de mercancías advierten que este mismo régimen de división del trabajo que los convierte en productores privados independientes hace que el proceso social de producción y sus relaciones dentro de ese proceso sean también independientes de ellos mismos, por donde la independencia de una persona respecto a otras viene a combinarse con un sistema de mutua dependencia respecto a las cosas" (T. 1, 
S. 1, cap. III, p. 73; recordemos que Marx había visualizado el comunismo como una inversión de esos términos, a saber como administración conjunta-cooperativa-consciente de los seres humanos sobre las cosas)

Al abordar la alienación de la actividad productiva del trabajador bajo contrato asalariado, Marx constata: "Si él [el obrero] se relaciona con su actividad como con una actividad no libre, se está relacionando con ella como con la actividad al servicio de otro, bajo las órdenes, la compulsión y el yugo de otro" (I 115).

Para resumir esa pérdida de libertad y autonomía del trabajador, Marx dirá varias veces que, en las condiciones del trabajo alienado capitalista, el obrero deviene máquina (por ejemplo en III 158).

Veamos como retoma esas ideas en El capital. Denunciando la falta de libertad del obrero dice: "La segunda condición esencial que ha de darse para que el poseedor del dinero encuentre en el mercado la fuerza de trabajo como una mercancía, es que su poseedor, no pudiendo vender mercancías en que su trabajo se materialice, se vea obligado a vender como una mercancía su propia fuerza de trabajo, identificada con su corporeidad viva" (T. 1, L. 1, S. 2, cap. IV, p. 130). Tal situación echa por tierra la imagen libre que la sociedad capitalista hace-divulga de sí misma (con la doctrina de los Derechos del Hombre), jurando que se basa en el libre contrato asentado en la libertad e igualdad de los poseedores de mercancías (ver T. 1, L. 1, S. 2, cap. $I V$, p. 138). En efecto, al analizar la acumulación originaria y comentando el decreto de Enrique VII sobre las explotaciones agrícolas (del que se ocupó Bacon en sus Essays, Civil and Moral), Marx constata que tal ley estipulaba "precisamente lo contrario de lo que exigía, para instalarse, el sistema capitalista, la sujeción servil de la masa del pueblo, la transformación de éste en un tropel de gentes a sueldo y de sus instrumentos de trabajo en capital" (T. 1, L. 1, S. 7, cap. XXIV, p. 660); tal sujeción se aseguró incluso vetando la libertad de emigrar para huir de la pobreza; así: "En el siglo XVIII, a los escoceses lanzados de sus tierras se les prohibía al mismo tiempo emigrar del país, para así empujarlos a la fuerza a Glasgow y otros centros fabriles de la región" (ídem, p. 669). Pero, en ese proceso los poderosos se aseguraron sus cotos de caza; en ellos, como dijo Robert Somers en carta al Times: "a la caza se la deja correr en libertad, sin tasarle el terreno; en cambio a las personas se las acosa y se las mete en fajas de tierra cada vez más estrechas...Al pueblo le fueron arrebatadas unas libertades tras otras" (ídem, p. 671). Para Marx, la condición asalariada en el capitalismo es aquella en la que un hombre (el trabajador) se ve "obligado" (o sea contrariado en su libertad) a "vender a otro su fuerza de trabajo", lo que significa "venderse a sí 
mismo" (por lo menos durante la duración de la jornada laboral) (ver T. 2, L. 2, S. 3, cap. X, p. 417). De hecho, trabajando como asalariado, el obrero deviene una "cosa" más en manos del capitalista: "... dentro de la producción capitalista el propio obrero, una vez que entra en el proceso de producción, pasa a ser por sí mismo un ingrediente del capital productivo en funciones y perteneciente al capitalista..." (T. 3, L. 3, S. 1, cap.l, p. 50).

Luego, esa falta de libertad se hará "natural" para los trabajadores: "La organización del proceso capitalista de producción ya desarrollado vence todas las resistencias", y "En el transcurso de la producción capitalista se va formando una clase obrera que, a fuerza de educación, de tradición, de costumbre, se somete a las exigencias de este régimen de producción como a las más lógicas leyes naturales" (T. 2, L. 2, S. 3, cap. X, p. 676).

Hay que notar que también el capitalista, verdugo de la libertad del trabajador, con quien nunca toma decisiones consensuales, es, a su turno, un individuo no libre, presionado por la lógica concurrencial del capitalismo (y por eso el comunismo, que ampliamos en ecomunitarismo, habrá de servir también para que el actual capitalista, despojado de tal función e integrado a la asociación libre de los productores libres, pueda realizar consensualmente su libertad de decidir): "La libre concurrencia impone al capitalista individual, como leyes exteriores inexorables, las leyes inmanentes de la producción capitalista" (T. 1, L. 1, S. 3, cap. VIII, p. 226). Sometido a una lógica que extrapola su libertad de decidir, el capitalista individual ni siquiera sabe cómo la plusvalía generada en su rama de producción contribuye a crear la ganancia media, pues "este es un proceso que se desarrolla a espaldas de él, que él no ve, que no comprende y que en realidad no le interesa" (T.3, L. 3, S. 2, cap. IX, p. 190).

MM por su parte, refiriéndose de hecho a los capitalistas, nos proporciona un panorama claro de la realidad e incompletad de la vigencia de la libertad de decisión exigida-amparada por la primera norma de la ética, cuando observa que la concurrencia capitalista "significa que la libre decisión de cada productor sobre a qué ha $\mathrm{d}$ dedicar su capacidad productiva, y la libre decisión de cada uno sobre qué productor prefiere adquirir por cambio, se encuentran ('concurren') en el mercado con las correspondientes decisiones igualmente libres de cada uno de los demás (en principio infinitos) individuos; pero ocurre que luego, en el mercado, esa libertad se verá limitada (y redireccionada, con el eventual cambio del capitalista a otro ramo productivo), pues es allí donde "cada uno asume el riesgo de que su actividad productiva sea o no confirmada a posteriori ...como socialmente necesaria" (p. 58), o sea, sea o no pasible de venta (y la consiguiente 
realización del valor, que incluye la plusvalía, encerrado en el producto, con lo que ello tiene de decisivo para la permanencia o no del capitalista en su rol de tal); como lo dice MM: "Cada uno conserva su libertad de decisión, y solamente un mecanismo ciego (que no es sujeto alguno ni individual ni colectivo) le hará saber si la decisión que adoptó es o no concorde con las exigencias de la sociedad y lo compelerá a aceptar esas exigencias si quiere vivir" (p. 60); quizá haya que acotar que en realidad el "mercado" sí es una especie de sujeto colectivo alienado, en la medida en que se constituye de las relaciones productivas alienadas contraídas-renovadas por los individuos.

\subsection{La cuestión de la temporalidad}

Creemos que la cuestión de la "temporalidad" de la vida del asalariado, magistralmente observadajuzgada por Arteta (p. 301 y ss.), hace parte de este panorama de la alienación de la propia libertad y autonomía. Nota AA primero la "alienación del tiempo individual bajo su forma social capitalista", y después "la alienación del individuo mismo en tanto que sometido a una temporalidad así formalmente determinada"; AA muestra cómo "bajo su forma capitalista, el tiempo del individuo es tiempo alienado tanto de sí (es un tiempo otro) como respecto del individuo mismo (deviene un tiempo de y para otro)". En el capitalismo la alienación del tiempo "consiste tanto en la independencia y dominio de sus determinaciones formales sobre sus componentes materiales, como en el vaciamiento de su substancia misma...- - o pérdida de su carácter individual o cualitativo- y su conversión en tiempo abstracto, en tiempo de la forma, como - en fin - en su sustantivación, autonomía y dominio sobre los individuos mismos" (p. 306); recordemos que en el capitalismo, donde el "producto sólo es social si es valor (y mide su magnitud por el tiempo de trabajo que encierra) el tiempo deberá ser, antes que cualquier otra modalidad, sólo tiempo de trabajo; mejor, tiempo de trabajo productor de tal valor, tiempo de trabajo abstracto; y, en cuanto tal, como medida de ese trabajo, pura cantidad (y no cualidad) de tiempo" (p. 304). Así, para el asalariado "incluso su tiempo libre es tiempo en el que se limita a reponer fuerzas para reiniciar su proceso de trabajo y, por ello, debe emplearlo 'productivamente'" (p. 308). Dice AA que los capitalistas "por contar con tiempo objetivad en cantidad suficiente (dinero en forma de capital constante y variable) emplean libremente su propio tiempo presente y el de los demás" (p. 308). (Como veremos la situación no es totalmente así, pues también al capitalista alcanza el vértigo coercitivo en la vivencia y uso del tiempo, en especial debido a la competencia a la que está sometido día a día). Por su parte, el asalariado "por no poseer sino tiempo presente (el que se actualiza en el ejercicio de su fuerza de trabajo) ha de ponerlo 
como tiempo de trabajo al servicio de aquel tiempo objetivado que no le pertenece" (p. 308). Recordemos que Marx describió la inversión temporal que en el capitalismo se da entre "tiempo necesario" y "tiempo excedente", en un doble sentido; por un lado, porque para el capitalista siendo el único tiempo interesante aquél en el que el trabajador crea plusvalía (catalogado técnicamente como "excedente"), pasa a ser un tiempo superfluo que hay que tratar de reducir al máximo, tanto el tiempo en el que el asalariado se limita a reponer en la producción el valor de su fuerza de trabajo (tiempo "necesario", técnicamente hablando, en la categorización marxiana), como aquél en el que el trabajador permanece fuera de la producción (en casa, por ejemplo, o sea 'improductivamente', pero de manera "necesaria" para su subsistencia y, más aún y de ahí la defensa marxiana de la lucha obrera por ampliar el tiempo libre, para su realización como individuo). AA observa que el "tiempo formal" que en el capitalismo mide al trabajo abstracto creador de valor, "es una alienación del tiempo real", es "un tiempo alienado, porque, a través del despojo de sus propia sustancia, ha generado el dominio de sus caracteres formales sobre los materiales"; y remata: "En definitiva, todos los tiempos individuales son devorados por el único Tiempo dEl capital, sometidos a él y por el mediados y regulados" (p. 317) Y así llegamos a la "sustantivación, autonomía y dominio del tiempo respecto del individuo", pues en el capitalismo el tiempo mismo del individuo se convierte en una mera partícula o soporte individual del tiempo general (p. 317). AA concluye: "EI tiempo del individuo, bajo esta determinación [la capitalista] resulta siempre un tiempo ajeno que en todo momento ah de enajenarse: en definitiva, la explotación capitalista no consiste en otra cosa que en un inmenso pillaje de tiempo humano, $y$ es en ese despojo reincidente donde descansa la riqueza actual" (p. 318); como vemos, esta formulación englobante de AA, supera su juicio anterior sobre el "tiempo libre de los capitalistas", y se compatibiliza con nuestra apreciación (que también Marx había señalado, aunque de paso) de la esclavitud temporal de la que también son víctimas los capitalistas, y no sólo los asalariados. Tal amplitud destaca más aún en las palabras con las que AA resume las conclusiones de todo el libro que comentamos: "A modo de conclusión, la forma capitalista albergada en el individuo exige de éste que no sea individuo personal propiamente dicho, sino Género, parte indistinguible de una Masa homogénea y uniforme; que no produzca sino lo que, cuánto, cómo, cuándo y para quién determine esta forma; que no ponga nada propio en su objetivación y se limite a personificar la Voluntad general ajena, que confunda sus fines personales con los de la Persona impersonal de la que es representante, esto es, 
que sea persona en su primitiva acepción de 'máscara' (portavoz, personaje) de la única Personalidad social; que no ejerza su racionalidad sino como mera depositaria de la Razón formal, que su autoconciencia no sea más que el reflejo particular de una Insconsciencia universal; que niegue sus necesidades individuales por su identificación con la necesidad de la forma, única necesidad que somete a todas las demás; que sacrifique su tiempo real a un tiempo abstracto y consienta en ser simple órgano del tiempo del capital" (p. 319).

\section{Conclusión provisoria y herética, coincidente con las dos primeras normas de la ética}

L

a crítica de la alienación en El capital, subsumida por las tres normas fundamentales de la ética nos lleva a la conclusión de que Marx postuló (sin que la gran mayoría de los supuestos marxistas lo percibieran) la superación de una de las tesis centrales del materialismo histórico, al esperar-desear que la consciencia debe determinar el ser social. Los manuales supuestamente marxistas han enseñado siempre lo contrario, y no sin razón, pues Marx efectivamente y también en El Capital, sostiene que en la existencia alienada (el énfasis es mío) "el ser social determina la consciencia"; pero repito: en la existencia alienada y en especial en el capitalismo; pues se olvida que el mismo Marx que expone la tesis de la pérdida del control por los individuos de sus decisiones y relaciones sociales (en violación de las dos primeras norma de la ética) es el que pregona, también en El capital la "expropiación de los expropiadores" (T. 1, fin del cap.
XXIV), para que los "productores libremente asociados" retomen el control de sus vidas; o sea para que su ser social sea determinado por su conciencia, lo que en el terreno de la producción-distribución-consumo pasa por la programación de la vida económica a través de un plan. Así dice, imaginando el comunismo: "...imaginémonos para variar una asociación de hombres libres que trabajen con medios colectivos de producción y que desplieguen sus numerosas fuerzas individuales de trabajo, con plena conciencia de lo que hacen, como una gran fuerza de trabajo social En esta sociedad se repetirán todas las normas que presiden el trabajo de un Róbinson, pero con carácter social y no individual....El producto colectivo de la asociación a que nos referimos es un producto social. Una parte de este producto vuelve a prestar servicio bajo la forma de medios de producción. Sigue siendo social. Otra parte es consumida por los individuos asociados, bajo la forma 
de medios de vida" ( T 1, L. 1, S. 1, cap I D, p. 45, el subrayado es mío; y ver, entre otros, T. 2, S. 1, cap. VI ítem 1b, T. 3, L. 3, S. 1, cap.VI ítem 2); y en otro momento Marx insistirá que "nos imaginamos la sociedad despojada de su forma capitalista y organizada como una asociación conciente y sujeta a un plan" ( T. 3, L. 3, S. 6, cap. XXXIX, p. 671, el subrayado es mío).

\subsection{Marx: un 'individualista'}

La superación de la determinación de la consciencia por el ser social, en la determinación del ser social por la conciencia, tiene en Marx, contrariamente a la fama de 'colectivista' que le han hecho incluso algunos supuestos 'marxistas', un claro acento individual (pues el fin propuesto para el orden poscapitalista es la libre y plena expansión de los individuos solidariamente asociados, y reconciliados con la naturaleza no humana, como lo exigen las tres normas fundamentales de la ética). Así dirá: "El sistema de apropiación capitalista que brota del régimen capitalista de producción, y por tanto la propiedad privada capitalista, es la primera negación de la propiedad privada individual, basada en el propio trabajo. La negación de la producción capitalista se producirá por sí mismo con la necesidad de un proceso natural. Es la negación de la negación. Ella muestra de nuevo la propiedad individual, pero sobre la base de los avances de la era capitalista: la cooperación de trabajadores libres y su apropiación colectiva de la tierra y de los medios de producción producidos a través de [su] propio trabajo" (T. 1, L. 1, S. 7, cap.XXIV, p. 705-706 de EAC, la traducción es nuestra; ver en EEC, T. 1, L. 1, S. 7, cap.XXIV ítem 7, p. 700). Nótese que por nuestra parte no adherimos a ninguna interpretación determinista y/o necesitarista de la Historia, considerando que la misma está siempre abierta y es el resultado de las decisiones que los individuos y comunidades tomen en cada circunstancia.

En lo que respecta al carácter 'individualizante' del 'reino de la libertad' acorde a la dignidad de la naturaleza humana, dijo Marx: "En efecto, el reino de la libertad sólo empieza allí donde termina el trabajo impuesto por la necesidad y por la coacción de los fines externos; él queda, pues, conforme a su naturaleza, más allá de la órbita de la verdadera producción material... La libertad en ese terreno, solamente puede consistir en el hecho de que el hombre socializado, los productores asociados, regulen racionalmente su intercambio material con la naturaleza, la coloquen bajo su control común, en vez de dejarse dominar por él como por un poder ciego, y lo hagan con el menor gasto posible de fuerzas y en las condiciones más adecuadas y más dignas de su naturaleza humana" (T. 3, L. 3, S. 7, cap. XLVIII, p. 826-827). 


\section{La crítica de Marx a la destrucción de la naturaleza humana y no humana en el capitalismo, a la luz de la tercera norma de la ética}

$\longrightarrow$

omo se recuerda, la tercera norma fundamental de la ética estipula que debemos preservar-regenerar una naturaleza humana y no humana sana (desde el punto de vista productivo).

Marx, en El capital, muestra de forma abundante y variada cómo tal norma es violada desde el origen por el capitalismo. Así, sintetizando en una frase final su análisis de la acumulación originaria del capital, y a la luz de las masacres, expulsión de poblaciones y su sojuzgamiento a la industria naciente en las peores condiciones de trabajo y de vida, Marx concluye: "Si el dinero, según Augier, 'nace con manchas naturales de sangre en un carrillo', el capital viene al mundo chorreando sangre y lodo por todos los poros, desde los pies a la cabeza" ( $\mathrm{T}$. 1, L. 1, S. 7, cap. XXIV, p. 697). Para llegar a esa conclusión Marx ha detallado-denunciado las condiciones de vida y labor de los trabajadores (por ejemplo en su estudio histórico de la jornada de trabajo, en el T. 1, S. 3, cap. VIII, en el estudio de la plusvalía relativa, en especial en T 1, S. 4, caps. X al XIII). Como la ganancia que va a determinar a posteriori la Ganancia Efectiva es el cociente entre la plusvalía y el total del capital desembolsado, es ley del capital hacer "economías" que per- mitan reducir el divisor de aquella proporción a fin de que crezca la ganancia. Esta "economía" opera, por ejemplo en el capital constante y se traduce, decía Marx ,"en el hacinamiento de los obreros en lugares estrechos y malsanos, lo que en términos capitalistas se conoce con el nombre de ahorro de edificios; en la concentración de maquinaria peligrosa en los mismos locales, sin preocuparse de instalar los necesarios medios de seguridad contra los peligros; en la omisión de todas las medidas de precaución obligatorias en los procesos de producción que por su carácter son atentatorios para la salud o que, como en las minas, Ilevan aparejados peligros".[T. 3, S. I, cap. V, p. 110]. Y prosigue: "La producción capitalista es siempre, pese a su tacañería, una dilapidadora en lo que se refiere al material humano, del mismo modo que en otro terreno, gracias al método de la distribución de sus productos por medio del comercio y a su régimen de competencia, derrocha los recursos materiales y pierde de un lado para la sociedad lo que por otro lado gana para el capitalista individual" (ídem). En ese contexto se constata la ausencia de medidas tendientes a "humanizar, hacer agradable o simplemente soportable para el obrero el proceso de producción"(ídem). 
Marx ya había constatado las enfermedades LER y DORT (ver arriba) provocadas por el capitalismo desde sus albores en la manufactura: "Es indudable que toda división del trabajo en el seno de la sociedad lleva aparejada inseparablemente cierta degeneración física y espiritual del hombre. Pero el período manufacturero acentúa ese desdoblamiento social de las ramas de trabajo de tal modo y muerde hasta tal punto, con su régimen peculiar de división, en las raíces vitales del individuo, que crea la base y da el impulso para que se forme una patología industrial" (T. 1, L. 1, S. 4, cap. XII , p. 318)

Resumiendo la situación global de inevitable ruina del hombre y de la naturaleza no humana mientras no se superase el capitalismo decía Marx en palabras que hoy no pueden sino considerarse con mucha atención: "La pequeña propiedad territorial presupone una mayoría de población predominantemente campesina y el predominio del trabajo aislado sobre el trabajo social; presupone, por tanto, la exclusión de la riqueza y del desarrollo de la producción tanto en cuanto a sus condiciones materiales como en cuanto a las espirituales también, por consiguiente, en cuanto a las condiciones de un cultivo racional. Por otra parte la gran propiedad sobre la tierra reduce la población a un mínimo en descenso constante y le opone una población industrial en constante aumento $y$ concentrada en grandes ciudades; y de este modo crea condiciones que abren un abismo irremediable en la trabazón del metabolismo social impuesto por las leyes naturales de la vida, a consecuencia del cual la fuerza de la tierra se dilapida y esta dilapidación es transportada por el comercio hasta mucho más allá de las fronteras del propio país (Liebig)... Si la pequeña propiedad territorial crea una clase de bárbaros colocados casi al margen de la sociedad y en la que toda la tosquedad de las formas sociales primitivas se une a todos los tormentos y a toda la miseria de los países civilizados, la gran propiedad de la tierra mina la fuerza de trabajo en la última región a que va a refugiarse su energía natural y donde se acumula como fondo de reserva para la renovación de la energía vital de las naciones: en la tierra misma. La gran industria y la gran agricultura explotada industrialmente actúan de modo conjunto y forman una unidad. Si bien en un principio se separan por el hecho de que la primera devasta y arruina más bien la fuerza de trabajo y, por tanto, la fuerza natural del hombre, y la segunda más directamente la fuerza natural de la tierra, más tarde tienden cada vez más a darse la mano, pues el sistema industrial acaba robando también las energías de los trabajadores del campo, a la par que la industria y el comercio suministran a la agricultura los medios para el agotamiento de la tierra". [T. 1, S. 6, cap. XLVII, p.819820]. Especificando su apreciación 
de la agricultura capitalista, dice Marx en palabras que tienen plena actualidad después de las experiencias de la llamada "Revolución Verde" hecha a base de agrotóxicos y fertilizantes artificiales: "...todo progreso realizado en la agricultura capitalista, no es solamente un progreso en el arte de esquilmar al obrero, sino también en el arte de esquilmar a la tierra, y cada paso que se da en la intensificación de su fertilidad dentro de un período de tiempo determinado, es a la vez un paso dado en el agotamiento de las fuentes perennes que alimentan dicha fertilidad" (T. 1, S. 4, cap. XIII, p. 454).

Enfocando el tema de la forestación (tema hoy acuciante, pues la forestación es impulsada por multinacionales que en Latinoamérica compran cientos de miles de hectáreas en Uruguay, el Sur de Brasil y Argentina) decía Marx: "El largo período de producción (que incluye un período relativamente corto de trabajo),y por tanto la larga duración de sus períodos de rotación, hace de los cultivos forestales una base de inversión poco favorable para una empresa privada $y$, por consiguiente, capitalista, la cual no perderá este carácter aunque en vez del capitalista individual la regente una sociedad capitalista. En general, el desarrollo de la cultura y de la industria se ha traducido siempre en la tendencia celosa a destruir los bosques y todo lo que se ha intentado para la conservación y producción de la riqueza forestal representa un factor verdaderamente insignificante al lado de aquella tendencia". Y luego destaca las siguientes palabras de un texto de Kirchof sobre esta cuestión: "Además, la producción forestal continuada requiere, a su vez, una reserva de madera viva, que representa diez y hasta cuarenta veces el rendimiento anual", para observar que esto significa una (y tan sólo una, poco tentadora, agrego yo) rotación del capital a cada diez o aún cuarenta años. [T 2, S. 2, cap.XIII, p. 229-230].

En base a esas consideraciones, concluyó que "la producción capitalista sólo desarrolla la técnica y la combinación del proceso social de producción socavando al mismo tiempo las dos fuentes de toda riqueza: la tierra y el trabajador" (T. 1, L. 1, S. 4, cap. XIII, p. 455).

Contra esta devastación cabe defender (a partir de la tercera norma de la ética), como lo hace Reyes Mate, el derecho a la vida como el primero de todos los derechos (Reyes Mate, 2008, p. 67 y ss). 


\section{Nuestro resumen-actualización del trabajo alienado en distintas actividades actuales}

10.1. Alienación del asalariado

Alienación del objeto de trabajo — n la producción de bienes "materiales" (que es la que aquí nos interesa) el objeto de trabajo merece ser considerado en dos momentos fundamentales: en aquel en que él antecede o hace parte del proceso de producción y aquel en que deja atrás este proceso al constituirse en "producto"(para entrar como tal en la esfera de la circulación). [Sabemos que hay "productos" que son usados por su vez como "objeto de trabajo" en un nuevo proceso de producción para dar origen a un nuevo "producto", diferente del utilizado como objeto de trabajo; no obstante la lógica de la producción capitalista y la lógica de la producción en general exige que todo proceso de producción desemboque finalmente en un "producto", "producto final", podríase decir, cuyo destino no es permanecer en la órbita de la producción sino ingresar a la de la circulación y a través de ésta a la del consumo].

En el primer momento al referirnos al "objeto del trabajo" nos las habemos de hecho con el objeto sobre el cual recae la actividad laboral (a través de la mediación del "instrumento de trabajo"), el cual en última instancia es un "pedazo de naturaleza" sobre el cual ha recaído algún o ningún trabajo humano.
Aquí tratamos pues del "objeto de trabajo" en cuanto que "producto final", o sea, fruto del proceso de producción volcado a la órbita del consumo a través de la circulación.

Constatamos que en el capitalismo contemporáneo el asalariado está alienado del producto de su trabajo, porque éste no le pertenece sino que pertenece al propietario del medio de producción donde trabaja el asalariado. La separación, de hecho privación, [en beneficio del capitalista], del producto de su trabajo por parte del asalariado es tan drástica que ocurre en el llamado Tercer Mundo que asalariados que producen alimentos vengan a padecer de hambre y aún a morir a causa de malnutrición. Si en el llamado Primer Mundo el peligro de la muerte por hambre no afecta (ipor ahora?) sino a minorías, y sin entrar en la cuestión de saber hasta qué punto este panorama no se hace posible precisamente a costa del hambre de vastas multitudes del Tercer Mundo, es un hecho no obstante que también allí el asalariado está tan separado-privado del producto de su trabajo como en este último. Y esto por la sencilla razón de que también allí el producto pertenece al capitalista y no al asalariado. Eso se transparenta entre otros hechos en la "pobreza relativa" evidente de la enorme mayoría de los asa- 
lariados respecto de los capitalistas cuando se compara en cantidad y calidad el nivel de sus respectivos consumos de bienes. Sintomática de esta alienación del asalariado respecto del producto de su trabajo es la reciente irrupción de la figura del "Consumidor" en la jerga de la economía a-crítica, de la propaganda y de los medios masivos de comunicación. Allí se nos habla de las "exigencias" o de las "preferencias" o de los "cuidados" o de la "ganancia" o de la "pérdida" del consumidor en tal o cual circunstancia económica relativa a la esfera de la circulación y del consumo. Mas cabe preguntarse: ¿Quién es ese "consumidor"? Obviamente la respuesta no puede ser más simple: en la aplastante mayoría de los casos ese famoso "consumidor" no es sino un asalariado. O sea el "consumidor" no es sino el productor considerado en el momento en que, a través de la "vía larga" del "mercado", intenta re-encontrarse con los productos de cuya elaboración ha participado en tanto que integrante de la red de productores del régimen social capitalista.[Régimen cuya producción, que es la más socializada de la historia de la humanidad se realiza no obstante en y con vistas al tráfico mercantil, lo que hace que sólo mediante la compra-venta de mercancías pueden ser satisfechas las diversas necesidades de la sobrevivencia y de la "vida confortable"]. La jerga antes citada separa la vida del mismo ser humano en dos compartimentos estanques: uno en el que aquel es productor y otro en el que deviene consumidor. Lo que no sospecha esa jerga es que ella patentiza-revela-confesa la alienación padecida por el asalariado respecto del producto de su trabajo en el régimen capitalista, régimen en el cual el asalariado puede ser presentado ( $y$ auto-percibirse) como dividido en dos figuras separadas y alternativas : las de "funcionario" y "consumidor" .Y si esto sucede es porque de hecho esa división existe sobre la base de la separaciónprivación del producto de su trabajo por parte del asalariado a manos del capitalista. [ Es de notar que ahora esa misma jerga dice "funcionario" o "colaborador" y "empleador" donde antes decía sin mala conciencia y quizá con menos dominio de la dimensión connotativa del lenguaje "obrero" o "empleado" por un lado y "patrón" por el otro].

Alienación de la actividad productiva

Por actividad productiva entendemos la desplegada por el asalariado en el proceso de trabajo mediante el cual éste contribuye a la gestación de un "producto". Esta actividad es desarrollada por el asalariado según las capacidades genéticas de la especie por él heredadas, perfeccionadas mediante el proceso educativo que antecede a su inserción social como "productor" (proceso este que a veces puede limitarse a ser un sinónimo de la simple convivencia con productores adultos). Lo que se constata es que cuando un ser humano pasa a ser asalariado y durante el tiempo de la jornada en que se desempeña 
como tal pierde el control sobre su propia actividad laboral. Quien pasa a ejercer tal control es el capitalista o un representante suyo por él designado. Esto sucede porque la capacidad laboral del asalariado es precisamente lo que éste vende al capitalista a cambio del salario; y como esa capacidad se actualiza (o sea, pasa de la "potencia" al "acto", deviniendo "real") en la actividad laboral el capitalista es el dueño de ésta (en los límites temporales de la jornada de trabajo) y como tal se comporta. Esta situación recibe confirmación y expresión por y a través del acto lingüístico que predomina en la relación entre el capitalista (o representantes suyos) y los asalariados en el espacio-tiempo de la jornada laboral: la "orden".

Discutiendo la poca atención dada por Apel a las relaciones comunicativas vigentes en el seno de la empresa capitalista y la vinculación a establecer entre éstas y las relaciones productivas allí en vigor he sometido a consideración en un trabajo anterior el imperio del acto lingüístico de la "orden" en dicho universo celular (de importancia sin duda fundamental en la arquitectura del organismo total de la sociedad capitalista) [cfr. López Velasco 1993 y 1994, 1a. parte y cap. I, 1a. parte, respectivamente]. Allí partía yo del hecho empírico que es la predominancia de la "orden" en el conjunto de los actos lingüísticos ejecutados por el capitalista (o alguno de sus representantes) y teniendo como destinatario a los trabajadores (en especial los de "bajo rango") en el espacio de la empresa y en el tiempo de la jornada laboral. Sobre esa base hacía notar cómo sobre la base del análisis austiniano de las reglas que presiden la "ejecución feliz" de los actos lingüísticos, podríase canonizar la asimetría comunicativa vigente en tal situación. Eso porque, ejemplificando un "infortunio" [infelicitie] producto de la violación de uno y/o ambos de los dos primeros tipos de reglas por él acuñadas, decía Austin: "on a desert island you may say to me 'Go and pick up wood', and I may say 'I don't take orders from you ' or 'you're not entitled to give me orders'. I do not take orders from you when you try to 'assert your authority' (which I might fall in with but may not) on a desert island, as opposed to the case when you are the captain on a ship and therefore genuinely have authority". (Austin, 1962, Conf. III:".en una isla desierta, otro puede decirme 'vaya a buscar leña', y yo contestarle 'no recibo órdenes suyas ' o 'usted no está autorizado a darme órdenes '.No recibo órdenes del otro cuando éste pretende 'afirmar su autoridad' (cosa que yo podría aceptar o no) en una isla desierta, en contraposición al caso en el que el otro es el capitán de un barco y por ello tiene autoridad legítima"]. Recordando que el Diccionario (Petit Robert,1983) define "orden", en el uso aquí relevante del término, como "acto por el cual un jefe, una autoridad, manifiesta su voluntad" Ilamaba la atención sobre la perfecta correspondencia 
existente entre aquella definición y el análisis austiniano del supracitado "infortunio", cuya conclusión por cierto no desagradaría a un buen prusiano; el problema es que la última frase de Austin podría terminar ,con ligera diferencia, como sigue: " en contraposición al caso en el que el otro es mi patrón y por ello tiene autoridad genuina". De esa manera recibiría canonización austiniana el imperio de la "orden" vigente en la empresa capitalista. Este resultado sería el indefectible punto de llegada de todo análisis que tan rigurosa como cándidamente se propusiera tematizar "procedimientos convencionales aceptados" empleados "por ciertas personas en ciertas circunstancias" sin ejercer la crítica de las relaciones sociales a partir de las cuales ciertos "procedimientos" devienen "convencionalmente" "aceptados" y que posibilitan la ejecución siempre a salvo del infortunio de ciertos actos lingüísticos por parte de "ciertas personas" en "ciertas circunstancias". En el caso considerado la pregunta a la espera de respuesta es la siguiente: ¿cuál es la condición de existencia del trabajador sobre la que se asienta la "aceptación" (en tanto que actos nunca "infortunados") por parte de aquél de las órdenes a él dirigidas en el espacio-tiempo del trabajo emanadas del capitalista (o alguno de sus representantes) en tanto que "persona apropiada" ? Responder a esa pregunta implica entrar en el universo de las relaciones productivas vigentes entre el capitalista y el trabajador.
En éstas, como apuntaba Marx,

a) El asalariado, que se encuentra separado de las condiciones objetivas de realización de su capacidad de trabajo como fuente creadora de los bienes necesarios para su subsistencia sólo puede superar esa separación y lograr aquellos bienes vendiendo su capacidad de trabajo al capitalista y

b) En la superación de esa separación mediante la forma citada " el trabajador como trabajador entra bajo el comando del capitalista" ["der Arbeiter als Arbeiter unter das Kommando des Kapitalisten tritt"] y su "trabajo vivo...como ocupación, utilidad de la capacidad de trabajo a él comprada" pasa a pertenecer (junto con el material de trabajo y los instrumentos de producción) al capitalista, a quien pasa a pertenecer pues la totalidad del proceso de trabajo; mas "visto que el trabajo es al mismo tiempo exteriorización vital del trabajador mismo, es ocupación de su propia realización y capacidad personal - una ocupación que depende de su voluntad [y] es al mismo tiempo exteriorización voluntaria de la misma - el capitalista vigila al trabajador, controla la ocupación de la capacidad de trabajo como una acción que a él le perteneciese". (Marx, 1861-1863; los subrayados son míos). [...Die lebendige Arbeit... als Betätigung Vernutzung des 
von ihm (N.B. der Kapitalist) gekauften Arbeitsvermögens gehören ihm, und gehört ihm der ganze Arbeitprozess. Da aber die Arbeit zugleisch Lebens - usserung des Arbeiters selbst, Betätigung seiner eigenen persönlichen Fertigkeit und Fähigkeit ist- eine Betätigung, die von seine Willen abhängt, zugleich Willensäusserung desselben ist - Uberwacht der Kapitalist den Arbeiter, kontrolliert sie Betätigung des Arbeitsvermögens als eine ihm gehörige Aktion.]

En El capital, Marx resume estas opiniones entre otras en el siguiente pasaje: "El obrero trabaja bajo el control del capitalista, a quien su trabajo pertenece. El capitalista se cuida de vigilar que este trabajo se ejecute como es debido y que los medios de producción se empleen convenientemente..." (Libro 1, S. 3, cap. V, p.147. ("Der Arbeiter arbeitet unter der Kontrolle des Kapitalisten, dem seine Arbeit gehört. Der Kapitalist passt auf, dass die Arbeit ordentlich vonstatten geht und die Produktionsmittel zweckmässig verwandt werden"; p. 155")].

Vemos que en el trabajo asalariado la orden dada por el capitalista es siempre "feliz" en la medida en que ella no se inscribe en el marco de una plena intersubjetividad. Ello porque en la relación asalariada el trabajador se reduce a ser simple "capacidad de trabajo" que pertenece al conjunto de "cosas" por medio de las cuales el capital recorre su ciclo de autovalorización y el capitalista, corporificación personalizada de aquél, afirma solipsísticamente en "su" empresa su subjetividad. [Para decirlo con palabras de Marx: "Desde su punto de vista (el del capitalista) el proceso de trabajo no es más que el consumo de la mercancía fuerza de trabajo comprada por él, si bien sólo la puede consumir facilitándole medios de producción. El proceso de trabajo es un proceso entre cosas compradas por el capitalista, entre cosas pertenecientes a él" $(E I$ capital, T. 1, L.1, S. 3, cap.V, p.147. ("Von seinem Standpunkt ist der Arbeitprozess nur die Konsumtion der von ihm gekauften Ware Arbeitskraft, die er jedoch nur konsumieren kann, indem er ihr Produktionsmittel zusetzt. Der Arbeitsprozess ist ein Prozess zwischen Dingen, die der Kapitalist gekauft hat, zwischen ihm gehörigen Dingen". p.155-156)]. Esa cosificación del trabajador reducido a "capacidad de trabajo" es tan fuerte que el capitalista se "confunde" y se toma por un dueño de esclavos a la vieja usanza al creerse propietario del cuerpo del trabajador, por ser el cuerpo la "sede" de la "capacidad de trabajo" de la que él es realmente dueño, como sucede en el asedio sexual del capitalista (o sus representantes) al asalariado/ asalariada de su empresa. Esa "confusión" se ve facilitada por el hecho de que realmente sucede que, por ser el propietario de la "capacidad de trabajo" cuya "sede" es el cuerpo del trabajador, el capitalista tiene la potestad de imponer su voluntad a 
ciertas facetas de la vivencia de ese cuerpo en el período de tiempo en que éste permanece en el local de trabajo. En efecto, el capitalista en tanto que dueño de la "capacidad de trabajo" del trabajador tiene poderes sobre ciertos de los "movimientos" del cuerpo de este último en el espacio-tiempo de la jornada laboral, poderes que son ejercidos tanto a través de la legislación laboral como por medio de "reglamentos" internos de la empresa. Así, por ejemplo, el capitalista tiene el poder de limitar la libertad de ir y venir del trabajador en el espacio de la empresa, aún cuando ese desplazamiento tenga por objeto la satisfacción de necesidades fisiológicas básicas como la de ir a la privada. El "reglamento" interno, que puede tener en todo o en parte carácter oral, se encargará de disponer sobre el número de veces al día en que el trabajador podrá abandonar su puesto para ir a la privada, como no dejará de aclarar el tiempo de permanencia en la misma que se juzga "conveniente" ; todo ello, claro está, acompañado de las correspondientes sanciones, incluida la destitución, en caso de trasgresión de las reglas. En la empresa la "orden" dada al trabajador, como podría serlo a un caballo, un buey o una máquina computadorizada, es el instrumento de la "vigilancia" y del "control" a los que se refería Marx.

Por otro lado el asalariado se ve obligado a la "aceptación" del "procedimiento de la orden" y de su invocación-realización por el capitalista o un representante suyo,"aceptando" la "felicidad" de cada una de sus ejecuciones en el seno de la empresa, porque de esa "aceptación" depende ni más ni menos que su propia subsistencia como asalariado y su propia subsistencia física como ser humano. En efecto, el desempleo con su cortejo de penuria absoluta o relativa en lo referente a las "necesidades" satisfechas mediante el salario, penuria que puede llegar a los límites de la indigencia y aún de la muerte, es el precio del cuestionamiento de tal "felicidad" y la siempre pendiente espada de Damocles del desempleo es la base de la instauración y perpetuación del referido "procedimiento" en cuanto que "convención aceptada".

Alienación de las capacidades humanas

a) El trabajo marcado por la obediencia a las "órdenes" es el ámbito donde el trabajador se ve obligado a alienar sus propias capacidades humanas (constituyentes de su "ser genérico", diría el Marx de los Manuscritos de 1844). Entre éstas destacan la "capacidad humana de trabajo" (producto de determinaciones genéticas y del proceso educativo) y la capacidad de argumentar (o sea de elaborar-proponer razonamientos) a partir y sobre la base del lenguaje humano (cuyos trazos específicos tanto Martinet como Chomsky 
han destacado. Ya hemos visto como en condiciones capitalistas el trabajador está alienado de su "capacidad de trabajo" en la medida en que ésta pasa a ser propiedad del capitalista. Esta situación incluye el hecho de que el trabajador no puede decidir en el espacio-tiempo de la empresa sobre el "cuál" ,el "cómo" y el "grado" de las habilidades que componen su "capacidad humana de trabajo" habrá de poner en acción. Por el contrario, su acción deberá poner en juego sólo aquellas habilidades indicadas por la "orden" recibida del capitalista (o uno de sus representantes) y en la forma y en el grado especificado por la misma. Las habilidades, o su forma o grado no contempladas por esa orden no deben ser ejercidas so pena de ser pasible de sanciones, entre las cuales figura la destitución, estipuladas en la legislación laboral como en los "reglamentos internos" de la empresa. Por su parte es obvio que no es permitido que el trabajador argumente, oponiendo razonamientos a las órdenes recibidas, ni ello es aconsejable si quiere conservar su empleo. Del trabajador, como del soldado, se espera que actúe, no que piense. Es interesante constatar que en ambas dimensiones, tanto la relativa al achicamiento de las habilidades constitutivas de la capacidad de trabajo específicamente humana (con la consi- guiente componente represiva de las habilidades "sobrantes") como en el cercenamiento de su capacidad de argumentar, el trabajador se ve literalmente animalizado en y por el trabajo alienado.

b) De ahí que en el trabajo en condiciones capitalistas el trabajo continúe mereciendo la etimología que lo vincula a la tortura del tripalium pues realmente es una actividad de la que el trabajador " huye como de la peste" (Marx 1844) cuando se ve libre de la coacción.

De ahí también que el trabajador se sienta "en lo suyo" ("zu hause", Marx, 1844) fuera del trabajo y no se sienta "zu hause" en él, o sea, que se sienta humano cuando desempeña actividades como el comer y beber, que el hombre comparte con los animales como característica común a ambos ,y se sienta animal cuando desempeña una de sus funciones específicas (que lo distinguen de los animales): a saber, el trabajo. (cfr. Marx 1844) .

¿Se piden ejemplos actuales que den pie a estas aserciones? Basta observar con cuánta alegría los trabajadores reciben en el capitalismo la llegada de cada día feriado y con qué impaciencia aguardan (cuando las tienen) las vacaciones anuales.

c) En el trabajo asalariado en condiciones capitalistas las ca- 
pacidades humanas son, pues: a) degradadas por la coacción y la rutina y b) se transforman en simple medio de subsistencia física (Marx 1844).

De lo primero ya nos hemos ocupado en detalle.

De lo segundo cabe decir que en ese trabajo aquello que constituye parte de la diferencia específica entre el ser humano y el animal, a saber la capacidad humana de trabajo, lejos de realizarse por el placer de su puesta en acto se ve reducida a un simple medio a través del cual el trabajador garantiza su subsistencia. O sea, lo que era digno de ser practicado como un "fin en síl (al igual que puede suceder con la capacidad de creación artística, otro rasgo distintivo del hombre respecto del animal) se ve reducido a medio (de subsistencia) al tiempo en que se degrada en su forma y en su contenido por el achicamiento y la rutinización de su espectro de acción. Esta mudanza puede Ilevar aparejada, en su brutal cercenamiento, una práctica patológica. No otra cosa quiere hacer comprender Chaplin en Tiempos modernos, a través de la conducta obsesiva, desembocando en lo patológico, en cuanto que "apretador de tornillos", de su personaje.

\section{Alienación del trabajo}

Aún cuando se pliegue a la eterna "felicidad" de las órdenes del capitalista "el trabajo mismo se convierte en un objeto del que el trabajador sólo puede apoderarse con el mayor esfuerzo y las más extraordinarias interrupciones"(Marx 1844). O sea: el desempleo ronda siempre al trabajador. ¿Se piden datos actuales que fundamenten esta afirmación? Basta el siguiente dato: según números de la OIT en abril de 2009, de la población mundial económicamente activa, en 2009 unos 210 millones de personas estarán desempleadas. Es obvio que esa alienación existe en la medida en que el trabajador está alienado tanto: 1) del objeto de trabajo (que si está en estado natural puro no es suyo porque es parte de la "naturaleza ajena" [ver la "Alienación de la naturaleza"] y cuando no lo está, porque es "materia prima" o "materia auxiliar" que no es suya), como, 2) del instrumento de trabajo. Ahora bien, separada de ambos la "capacidad de trabajo" del trabajador se queda sin sus medios materiales de ejercicio y aplicación que son precisa y respectivamente, el instrumento de trabajo (herramienta o máquina que el trabajador interpone entre él y el objeto del trabajo y mediante el cual este último es transformado en "producto"), y, el objeto de trabajo (el "material" que la capacidad de trabajo es capaz de transformar en producto sirviéndose del instrumento de trabajo).

\section{Alienación del otro hombre}

...la sociedad civil es el campo de batalla de los intereses individuales de todos contra todos...

W.F. Hegel (Principios de la Filosofía del Derecho, 289) 
Que el ser humano es un "ser social" es cosa que hemos mostrado, a la luz de la lógica de la producción, en el cap. IV de mi Ética de la producción: Fundamentos (López Velasco 1994). Ello quiere decir, en resumen muy apretado, que cada ser humano no se constituye como ser humano sino en la medida en que hace parte de una comunidad humana; o sea en que es un "nudo" de una red de relaciones en la que cada nudo es un ser humano. Ahora bien, en las condiciones del trabajo alienado vigente en el capitalismo, cada ser humano se ve privado de esa vinculación interhumana. Marx defendió la tesis de que el trabajo alienado hace que las relaciones humanas se cosifiquen dándose a través de cosas y apareciendo como relación de esas mismas cosas, en la misma medida en que, por fuerza del fetichismo (en especial de la mercancía), "personifica" a cosas, ejecutando así una transmutación dialéctica de sujetos en objetos y de objetos en sujetos. Lo que aquí me interesa destacar es que aquella relación social en la que y mediante la que cada ser humano se constituye como ser humano asume en el capitalismo el rostro de la competencia y de la indiferencia, en resumen: se niega en el individualismo. La competencia tiene por escenario tanto los vínculos entre capitalistas y trabajadores como aquellos existentes entre capitalistas y aún los vigentes entre trabajadores. La indiferencia recíproca, por su parte, se instala como tendencia generali- zada y creciente. En el capitalismo, ni el objeto de trabajo, ni el instrumento de trabajo, ni la capacidad de trabajo (después que ella fue vendida por su poseedor, y sólo siendo vendida ella puede reunirse, como hemos visto, con el objeto y el instrumento de trabajo), ni el producto del trabajo pertenecen a los trabajadores sobre los que descansa la producción ,sino que pertenecen al capitalista que los emplea. De ahí la hostilidad abierta o velada, actual o potencial entre capitalistas y trabajadores. La competencia entre capitalistas, en la medida en que éstos son "personificaciones" de los respectivos capitales en competencia, es un hecho empírico que, lejos de negarlo, el capitalismo lo convierte en una virtud que divulga propagandísticamente como actitud vital formadora del carácter humano sin más y por ello merecedora de anidar en todas las relaciones entre individuos. [Esto no obsta para que, en la realidad del capitalismo, esta competencia entre capitalistas se transforme a cada momento en su contrario, a saber, en "cartel" (pasándose entonces a la competencia entre "carteles" en un nuevo giro dialéctico).. Transcendiendo la esfera de lo "económico" considerado en sentido estrecho la realidad del "cartel" se hace visible cuando ciertas acciones de los asalariados, por su amplitud y/o radicalidad, tienen por respuesta la reacción unificada de los capitalistas, a veces abierta y explícitamente coordenada por una asociación representativa de éstos]. Esa competencia se es- 
tablece también entre los propios trabajadores en particular porque, como ya vimos, el trabajo es un "objeto" del cual el trabajador está en permanente amenaza de verse alienado, y como del trabajo asalariado depende la satisfacción de las necesidades propias a la subsistencia del trabajador (en última instancia depende su propia vida y la de su familia), los trabajadores se enfrentan entre sí para tratar de asegurarse el acceso y la permanencia al y en el trabajo. [Es obvio que de esta competencia se servirá el capitalista para aumentar su ganancia, sea por medio de la disminución directa y absoluta de los salarios, sea por otros medios como el del aumento de la productividad a partir de la incitación y exacerbamiento de la situación objetiva de competencia existente entre los trabajadores]. Que la indiferencia recíproca generalizada se instala en el capitalismo como tendencia creciente lo muestran en la actualidad algunos hechos como, entre otros, los siguientes:

a) Somos legión los que pasamos ante seres humanos que necesitan ayuda, sea porque están siendo objeto de agresión física directa, sea por su situación de miserabilidad, por ejemplo cuando están tirados en la vereda, y sin embargo, seguimos de largo como si no los viéramos.

b) Si esa indiferencia ganaba terreno en la familia europea primermundista (familia nuclear mucho menor que la familia de los inicios del capitalismo) haciendo necesarias en Alemania las leyes que obligaban (!!) a los padres a ocuparse de la subsistencia de sus hijos hasta cierta edad (cerca de 30 años, suponiendo que esta es la edad aproximada en que en aquel país un estudiante medio puede terminar una carrera universitaria y con ello conquistar su autonomía financiera), por cierto sin que ello obste para que los hijos "retribuyan" poniendo en asilos a sus padres cuando llegan a la ancianidad, el Brasil tercermundista muestra que no se queda atrás y no quiere quedarse atrás ni en los hechos ni en la legislación al proclamar recientemente una ley que obliga (!!) a los hijos a ocuparse de la subsistencia de sus padres ancianos cuando éstos no pueden subvenir a sus necesidades por cuenta propia.

La alienación en el asalariado "no proletario"

Es un hecho que con el paso del tiempo se ha verificado en el capitalismo una disminución del número relativo de trabajadores manuales operando en la esfera de la producción "material". El número de esos "proletarios" decreció relativamente (y en algunos casos también en términos absolutos) en la medida en que aumentaba la participación en la "producción" (considerada en sentido amplio, o sea además de incluir todas las actividades volcadas a la creación de 
un producto y ya no solamente las directa e inmediatamente productoras del mismo, abarcando también las esferas de la distribución y el intercambio de productos) de otros asalariados. Entre éstos será objeto de nuestra atención la condición laboral de los "operadores", los científicos y los funcionarios administrativos.

Operadores y trabajo alienado

Llamo "operadores" a aquellos asalariados que, participando de la actividad directa e inmediatamente creadora de un cierto producto lo hacen a través de la vigilancia de dispositivos maquinísticos (a veces dotados de control digital) que son los responsables inmediatos, en sistema automático (como es el caso de los "robots" empleados en la cadena de montaje) o semiautomático, por la actividad productora propiamente dicha. Si exceptuamos la relativa "pulcritud" física que a veces caracteriza a su ambiente de trabajo y la distancia salarial que los separa de los trabajadores manuales no veo diferencia alguna entre el trabajo alienado practicado por unos y otros. En efecto, así como sucede con el trabajador manual, este "operador":

a) Está alienado del objeto y del instrumento de trabajo (pertenecientes al capitalista);

b) Logra apropiarse del propio trabajo sólo a través de mucho esfuerzo (en situación de competencia con otros "operadores") y siempre bajo la amenaza de esa "interrupción", ora temporal, ora definitiva, que es el desempleo;

c) Está alienado de su propia capacidad de trabajo (después de que ésta fue vendida al capitalista);

d) No decide sobre el "qué" producir, ni sobre el "cómo " hacerlo, porque ambas decisiones pertenecen al capitalista; el taylorismo se encargará de prescribir la cantidad y calidad de los movimientos que le son exigidos y el ritmo de producción le será dictado por el capitalista a través del ritmo impuesto al complejo maquinístico que el operador integra en la calidad de "recurso humano";

e) Está alienado de la naturaleza, a partir del hecho de que ésta, habiendo sido apropiada por el capitalista, deja de ser para el "operador" tanto un manantial de medios inmediatos de subsistencia como fuente proveedora de objetos $y / 0$ instrumentos de trabajo;

f) Está alienado de sus facultades humanas en la medida en que de él se exige, no que piense y argumente, sino que (al igual que el soldado) obedezca las órdenes recibidas y por eso mismo se ve privado de la posibilidad de desarrollar una actividad productiva creativa ;

g) Está alienado del otro hombre en la medida en que para conquistar y mantener su puesto de trabajo está en relación 
conflictiva con el capitalista (comprador de su capacidad de trabajo, con el que se enfrenta en tanto que vendedor en el eterno regateo entretejido de presiones y amenazas en torno al valor de la fuerza de trabajo, o sea del salario), y está en competencia (a veces real y ,siempre, virtual) con el conjunto de los otros "operadores" (por lo menos los que actúan en su misma especialidad);

h) Está alienado del producto de su actividad laboral con el que podrá re-encontrase (si puede hacerlo, dado su poder adquisitivo) sólo a través de la "vía larga" del mercado, en tanto que "consumidor".

El científico y el trabajo alienado

Cada día, el capitalismo reafirma e intensifica el uso de la ciencia como una fuerza productiva de vital importancia. Si en el área de la actividad inmediata y directamente productiva también las Ilamadas "ciencias humanas" (en especial, la Psicología, utilizada como herramienta para la selección y el entrenamiento de los asalariados) son usadas como fuerzas de producción, es evidente que se destacan en este papel las llamadas "ciencias naturales" (en especial, la física, la química y la biología) con el concurso de las "ciencias formales" (en especial, la lógica formal, la matemática y sus correspondientes extensiones, como lo es la informática). [Ningún robot industrial sería posible sin la combinación de conocimientos extraídos de, por lo menos, la física y la informática].

Legiones de científicos, trabajando en laboratorios vinculados más o menos directamente a empresas o directamente pertenecientes a ellas, pasan a ser agentes indirectos de la actividad productiva. La pregunta es: ¿trátase o no aquí de trabajo alienado?

A esta pregunta daba yo la misma respuesta afirmativa que doy ahora en un trabajo anterior (López Velasco 1994, cap. I.4). Contra la idílica imagen popperiana de una comunidad científica guiada por el deseo de aproximarse de la verdad mediante el recurso del falseamiento sucesivo de hipótesis (Karl R. Popper, 1959) ya blandía Thomas Kuhn (Kuhn 1962) la evidencia de la existencia masiva de lo que él Ilamó "ciencia normal". En ésta, lejos de preocuparse con la audaz elaboración de hipótesis y la realización de castos tests destinadas a falsearlas, el científico se encuentra él, en cuanto individuo, en situación de "elemento sometido a test". Ello porque de él se espera que partiendo del paradigma en vigor (que es excluido así de la dinámica de la falsación) sepa dar soluciones a cuestiones puntuales ("rompecabezas"); soluciones de las que dependen la manutención de su empleo y la conquista de los subsidios financieros que posibilitando la continuación de su labor son también elementos constitutivos de su prestigio profesional y personal, 
Ilave de las puertas que conducen a nuevos trabajos y subsidios. Esta observación de Kuhn gana profundidad crítica cuando se la ubica en el contexto que es el de la utilización de la ciencia como fuerza productiva en el capitalismo. Lo que me parece decisivo es el hecho de que en ese contexto el científico pasa a ser asalariado directo o indirecto del capitalista. Es su asalariado directo cuando trabaja en el espacio de la empresa y lo es indirectamente cuando (por ejemplo trabajando en una Universidad, sea ella pública o privada) depende de la financiación oriunda del capitalista para garantizar su salario (además de otras condiciones de su actividad como instrumentos y materiales de investigación).

Dado este cordón umbilicalsalarial que une al científico con el capitalista, no es de extrañar que éste le exija, en el marco de la "ciencia normal", "soluciones" capaces de proveerlo de innovaciones tecnológicas que le permitan enfrentar con éxito (y con las periódicas ventajas de la ganancia extraordinaria que proporciona el aprovechamiento en situación de monopolio temporal de una innovación tecnológica recién incorporada al proceso productivo) la feroz guerra de competencia a la que está sometido. hora bien, dada esa situación de vasallaje salarial el científico se ve condenado en la "ciencia normal",como el trabajador manual, a una actividad (la propia "ciencia normal") que no es libre exteriorización de sus energías vitales creadoras sino simple medio de subsistencia.

Mas, podríase preguntar: ¿Valdrá el modelo popperiano de la actividad científica para lo que Kuhn denominó, en contraposición a la "ciencia normal", "ciencia revolucionaria"? La "ciencia revolucionaria" es para él la actividad de los científicos que, desafiados por anomalías persistentes presentadas por el paradigma establecido, se dedican a cuestionarlo y a proponer, para sustituirlo, un nuevo paradigma explicativo de los fenómenos en cuestión. Ha de verse no obstante que tampoco esta "ciencia revolucionaria" escapa a la dependencia financiera (directa o indirecta, o sea vía poder político) respecto del capitalista. Mas el capitalista, en tanto que proveedor de recursos no deja de orientar selectivamente a la "ciencia revolucionaria" en las direcciones susceptibles de ofrecer resultados prometedores en la esfera de su aplicación tecnológicoproductiva $y$, dentro de las áreas elegidas, de establecer plazos de transformación de la investigación volcada a la "ciencia revolucionaria" en investigación aplicada (o sea del nivel de la "ciencia normal"), plazos que no deben ser transgredidos so pena de ver anulada la contribución financiera que hace posible la propia investigación. En el capitalismo la busca consensual y colectiva de la verdad mediante el falseamiento sucesivo de hipótesis sometidas a discusión pública en el ámbito de la 
comunidad científica está sometida a una dinámica contradictoria. Por un lado ella es incentivada a la luz de la competencia entre capitales (y en esta medida la producción capitalista es la base históricomaterial sobre la cual se hace posible y necesaria la emergencia de esa busca, que Peirce caracterizara como "socialismo lógico"), pero por otro lado ella encuentra sus límites en esa misma lógica de la competencia. Esos límites son los de su "encorsetamiento" al interior de las áreas problemáticas relevantes dentro de esa lógica y de los "plazos de retorno rentables" a la luz de ella. Por de pronto esto último significa que el científico, sea él dedicado a la "ciencia normal" o a la "ciencia revolucionaria", desde que ésta funcione como fuerza productiva subsumida directa o indirectamente por el capital, ni más ni menos que el trabajador manual empleado por éste:

a) Está alienado del producto resultante de su trabajo (porque éste pertenece al capitalista); b) Está alienado de su actividad porque, no siendo poseedor del objeto y del instrumento necesarios a su actividad, no es él quien decide del "qué" y del "cómo" de su despliegue, en particular en la medida en que este último se encuadra en áreas y plazos no determinados por el científico y sí por el capitalista;

c) Está alienado de la naturaleza a partir de la circunstancia de que ésta, apropiada por el capital, deja de ser para el científico fuente, tanto de medios de subsistencia inmediata, como de medios de trabajo, o sea, en concreto, de objetos e instrumentos de trabajo (entendiendo aquí "trabajo" según el uso amplio que permite incluir a la actividad propia del científico en tanto que actividad indirectamente propiciadora de la transformación con fines de apropiación de la naturaleza por el hombre);

d) Está alienado de sus facultades humanas porque por un lado en tanto que ejecutor de la actividad que es la suya ( o sea la de "científico") en el contexto de una división social del trabajo donde los individuos se ven obligados a utilizar sus capacidades (reducidas a simple medio de subsistencia) en el ejercicio de una única función, se ve privado de desarrollar otras facetas de sus aptitudes (como por ejemplo las requeridas por la actividad directamente productiva o por la creación artística); por otro lado porque los límites de su capacidad de argumentar (ejerciendo así otra facultad exclusiva de los seres humanos) están definidos para el científico, como lo estaban para el trabajador manual, por su condición de asalariado, condición que, como vimos, aconseja y en la práctica obliga al cumplimiento de órdenes 
(para el científico pudiendo ser ablandadas bajo el disfraz de "indicaciones",en especial en lo referente a "áreas preferenciales" y "plazos razonables" relativos a su actividad) si se quiere evitar el fantasma del desempleo ;

e) Está alienado del otro hombre porque, como el trabajador manual, encuéntrase en situación de permanente relación conflictiva con su patrón y en situación de competencia permanente con sus semejantes, en este caso los otros científicos capaces de disputarle "su" empleo y "sus" financiamientos. [Esta situación de competencia, vale la pena decirlo, lleva a la violación del auto-obligativo "Debo decir lo que creo ser verdadero", base del a-priori consensual de la argumentación que fundamenta la busca consensual de la verdad por la que se pauta la comunidad científica y que define a la propia ciencia contemporánea; aunque la propia comunidad científica guarda mucha discreción sobre este hecho, por evidentes intereses corporativistas. (Ver Jorge Dómine, 1992).

El funcionario administrativo y el trabajo alienado

Doy por un hecho evidente el que el funcionario administrativo de bajo rango (el Ilamado "cuello blanco") no por la circunstancia de trabajar en un escritorio escapa de la alienación característica del trabajador manual. [Aquí otra vez utilizo el término "trabajo" según el uso amplio empleado para referirme a la labor del científico.] En efecto ese asalariado:

a) Está alienado del producto para cuya producción contribuye [Nótese que también la actividad desarrollada en el área del transporte y comercialización contribuye a la producción del producto de que se trate en la medida en que sin la realización del valor contenido en él mediante su venta no recomenzará la producción del mismo, por lo menos por la empresa considerada; esto último es lo que sucede en los casos de falencia acontecidos en situación de crisis de superproducción.];

b) Está alienado del objeto e instrumento de su "trabajo" (en la medida en que no es propietario del material y de las máquinas existentes en la oficina en que actúa, en resumen no es dueño de esa misma oficina) ;

c) Está alienado de la naturaleza (a partir del hecho de que ésta no es para él proveedora de medios inmediatos de subsistencia ni de medios de trabajo), de su actividad productiva, de sus facultades humanas (en especial de aquellas no movilizadas por su labor de "servidor administrativo");

d) Está alienado, en fin, del otro hombre, por la conflictividad 
dades básicas del desempleado, del padre de familia estresado por la lucha por la satisfacción de las necesidades de ésta, o del jubilado, "limón ya exprimido" que necesita subsistir en circunstancias en que el salario ya no existe. Ante estos asalariados como él que se le enfrentan como demandantes de servicios tremolará con los más vivos colores de la indiferencia, la mala voluntad y/o la agresividad abierta, la bandera de la alienación respecto del otro hombre padecida por el funcionario].

\subsection{La alienación de los asalaria- dos en el "capitalismo de acumula- ción flexible".}

Actualmente, a la luz de transformaciones ocurridas, se habla de la existencia de una modalidad nueva del capitalismo, Ilamada "capitalismo de acumulación flexible", para diferenciarlo de la forma anterior denominada "fordista-taylorista" (en alusión a los métodos productivos preconizados por Henry Ford y F. W. Taylor). Las características nuevas, que, como opuestos de las existentes antes, singularizan el "capitalismo de acumulación flexible" son:

a) Gestión de stocks menores a través del método "just in time";

b) Descentralización de las grandes empresas en unidades de producción menores organizadas en base a una labor supuestamente participativa de 
los asalariados; c) Tercerización de la producción mediante la subcontratación; d) Contrato de trabajo flexible en diversas modalidades que incluyen el contrato clásico, el temporal y el de trabajo a domicilio; e) Obsolescencia programada de los productos.

La pregunta, en función de nuestros actuales propósitos, es: ¿en qué medida la alienación del asalariado por nosotros descrita se aplica a la situación del "capitalismo de acumulación flexible?". Para responderla, me dedicaré a analizar la situación laboral vinculada a estas características, con excepción de la primera y la última, pues la gestión de stocks menores no afecta la relación capitalista-asalariado sino cuantitativamente, es decir, en lo relativo a la disminución de los asalariados contratados para lidiar con esa gestión, y la obsolescencia programada de los productos no se vincula sino indirectamente a aqueIla relación a través de la necesidad para el asalariado de renovar en tiempo más breve bienes cuyo valor determina el valor de su fuerza de trabajo.

Descentralización empresarial y administración "participativa"

A lo dicho anteriormente se podría objetar que la producción del capitalismo flexible" no es ese "reino de la orden" por nosotros descrito porque se han abierto formas de participación del asalariado en el quehacer de la Empresa. A ello respondo que esa tan mentada "participación" además de tener por escenario un número de empresas grandes y medianas ridículamente pequeño al ser comparado con el total de empresas capitalistas existentes en el mundo (donde son billones las microempresas y las pequeñas empresas, las que a pesar de su tamaño emplean masas de asalariados no despreciables; por ejemplo $60 \%$ de los mismos en el Brasil de 1994, según la propaganda televisiva de la Asociación de las micro y pequeñas empresas) se reduce a una seudoparticipación en la que lo único que está en juego es la contribución que el asalariado puede dar con vistas al aumento de la productividad, sin que le sea permitido, ya no decidir, sino siquiera opinar, sobre "qué" y "donde" produce-vende la empresa y sobre "cómo" distribuye y administra ésta sus recursos financieros; en esta seudoparticipación, la contribución a él solicitada se reduce a pedirle que ayude a elevar el "cuánto" (absoluto y relativo, esto es en función de un recurso y tiempo dado de producción) y el "cómo" (la calidad) de un producto cuya fabricación fue determinada por otros. Ejemplo de esto es el programa japonés denominado "5 S" (Programa de las cinco "eses") divulgado propagandísticamente con bombo y platillo por muchos "modernizadores" en el Tercer Mundo (y aún en el Primero) como la última palabra en materia de "administración participativa". En efecto el mencionado programa dice fundarse en la "participación 
intensa de todos los empleados" [de la empresa] y promete, entre otros resultados, el "ejercicio de una administración participativa". No obstante, cuando vemos la propia definición que el programa da de cada una de las famosas cinco "eses" y de los otros resultados prometidos, nos percatamos de la indigencia de la mentada "participación" de los empleados en el contexto de la empresa.

En efecto:

— "Seiri" equivale a "sentido de la utilización" y consiste en la clasificación de las cosas y datos de acuerdo con su utilidad, con el consecuente descarte de los ítems innecesarios.

- "Seiton" equivale a "sentido del ordenamiento" y consiste en la disposición sistemática de los items útiles de manera que éstos sean localizados rápidamente.

_-Seisou" equivale a "sentido de la limpieza" y consiste en la ejecución rigurosa de la limpieza (en especial de las máquinas) y en la promoción y creación del hábito de no ensuciar.

- "Seiketsu" corresponde aproximadamente a "sentido del aseo" e, incluyendo tanto a empleados como a máquinas y materiales de producción, aparece como resultado de la aplicación conjugada de los tres "eses" anteriores.

- "Shitsuke", por último, equivale al "sentido de la autodisciplina" (del empleado) y es presentado como sigue: "Este es el sentido más importante, pues quien lo posee no necesita ser controlado". [EI énfasis es mío].

A su vez los resultados prometidos por el programa son, además del mentado "ejercicio de la administración participativa": "Mejora de la moral de los empleados, reducción del índice de accidentes, mejora de la calidad y de la productividad y reducción del tiempo de inmovilización de las máquinas". No hace falta mucha astucia para percibir que las cinco "eses" están en función de estos últimos resultados y no de la mentada "participación" del trabajador en la "administración" de la empresa. Lo único que el trabajador es invitado a "administrar" es el mejor uso racional (de la racionalidad conforme a fines) de los recursos productivos, incluyendo entre ellos su propia actividad productiva, de forma a ahorrar al capitalista las molestias y , principalmente, los gastos del control sobre la actividad del trabajador, como magníficamente lo confiesa la última "ese"; y todo ello, en función de la mejora en la cantidad y calidad de la producción (para garantizar, esto es lo que no dice el programa, una mayor ganancia al capitalista).

Como se ve en el último "ese" la novedad "modernizadora" en materia de "órdenes" y de la "vigilancia" y el "control" a que hacía referencia Marx en el universo de la empresa se resume al hecho de que ahora cada trabajador es el capataz (o " encargado de turno ", 
o como se le llame) de sí mismo, autoinfligiéndose las "órdenes" que garantizan (para mayor ganancia del capitalista) la mejor productividad en cantidad y calidad. Mas lo interesante es que ese perfecto ejercicio de ascetismo alienado no se conforma con la autocastigo, sino que alcanza a través de la práctica de la "democracia" (aclaremos a la luz de lo antes dicho: de una seudodemocracia relativa a medios para alcanzar fines que escapan completamente al poder de decisión de los participantes de la supuesta discusión democrática) a sus compañeros de infortunio. En efecto, comentando el último "ese" se dice en el programa: "La persona con autodisciplina discute hasta el último instante, pero ejecuta lo que fue decidido por el equipo aún cuando su opinión haya sido contraria a esa decisión". Es obvio que el " equipo " y su animada discusión no tienen ni la más remota posibilidad de plantearse como asunto, por ejemplo, ni el "qué" está Ilamado a producir ni, mucho menos, la diferencia cuantitativa existente entre el dinero que mensualmente entra respectivamente en la casa del trabajador y en la del capitalista.

Que estas cuestiones irrelevantes no entren en la animada discusión democrática del "equipo" es cosa que garantiza la interpretación de la "autodisciplina" a manos del referido programa cuando éste aclara que: "Seguir los parámetros técnicos, éticos y morales que rigen a la organización en la cual se ha decidido trabajar...hace parte de la esencia de quien tiene ese sentido [N. B.: la autodisciplina] desarroIlado".

Que esos "parámetros" le son impuestos al "equipo" y a cada trabajador por el capitalista (y sus representantes dentro y fuera de la empresa) como cánones que deben ser "seguidos" sin discusión posible es cosa que el programa se encarga de no aclarar. Esa imposición, que hace parte de la supuesta "decisión" referida en el pasaje relativo a "... la organización en la cual se ha decidido trabajar", tiene por base la simple y prosaica necesidad por parte del trabajador de ser admitido en alguna empresa para no morirse de hambre (o pasar a ser dependiente de la caridad de la seguridad social). Por otro lado dice mucho más de lo que piensa decir el referido programa cuando afirma que esa "autodisciplina" hace parte de la esencia del trabajador que la posee ; en efecto esa autodisciplina es parte del trabajo (y del trabajador) alienado. De esa "autodisciplina" hace parte el auto-sometimiento del trabajador al papel de un engranaje más de un proceso de trabajo que lo engloba y escapa a su voluntad, en especial mediante la asunción del ritmo de trabajo que le es impuesto a través del ritmo de las máquinas (regulado por el capitalista o un representante suyo) y de la ejecución de los movimientos que le son prescritos (taylorismo mediante, por el capitalista o uno de sus representantes, o ahora, por el 
"equipo" y/o por el propio trabajador en cuanto capataz de sí mismo) a efectos de acompañar y mantener ese ritmo.

\section{Subcontratación}

Como la subcontratación ocurre a través de pedidos hechos por grandes empresas a empresas pequeñas para que éstas asuman parte del proceso productivo destinado a la elaboración de un cierto producto habremos de ver en ella un fenómeno que no altera en las segundas el "universo de la orden" descrito por nosotros porque, según la hipótesis que antes esbocé, la supuesta "administración participativa" abarca (casi) exclusivamente al conjunto de las grandes empresas en proceso de descentralización.

Nuevas formas del contrato de trabajo

El "capitalismo de acumulación flexible" debe su nombre en especial a la flexibilidad impuesta a los regímenes de contrato laboral. Según una publicación de 1986 del Institute of Personnel Management [intitulada "Flexible Patterns of Work" y cuyo resumen hace David Harvey (en Harvey 1989), de cuya versión portuguesa voy a servirme, p.143 y ss.] la nueva situación de esos regímenes se presenta como sigue. La "nueva empresa capitalista" se articularía en torno a un Grupo Central de asalariados que ocupan posición esencial para el futuro a largo plazo de la empresa, beneficiarios de contrato laboral clásico (o sea por tiempo integral, indetermi- nado y con media de cuarenta horas semanales) pero con flexibilidad funcional y flexibilidad de la carga horaria semanal real en función de las necesidades de la producción. En torno de este grupo girarían dos Grupos Periféricos en situaciones laborales muy diferentes. Uno, Ilamado Primer Grupo Periférico, está formado por "empleados en tiempo integral pero dotados de habilidades fácilmente disponibles en el mercado de trabajo, como el personal del sector financiero, secretarias y el personal de las áreas de trabajo rutinario y de trabajo manual menos especializado". [Este grupo, con menos oportunidad de "hacer carrera en la empresa" que el Grupo Central, tiende a caracterizarse por una alta tasa de rotatividad, "lo que torna relativamente fácil, por desgaste natural, las reducciones de la fuerza de trabajo"]. El Segundo Grupo Periférico "ofrece una flexibilidad numérica todavía mayor e incluye empleados en tiempo parcial, empleados casuales, personal con contrato por tiempo determinado", subcontratación y 'pasantes' (o sea, personal, principalmente jóvenes, que realizan 'pasantías', entrenamiento productivo de capacitación profesional, a veces financiados por el poder público); a ellos habría que agregar todavía, como parte del vínculo de "subcontratación" o independiente de éste el trabajador a domicilio. Este grupo se caracteriza por tener todavía menos seguridad de empleo que el primer grupo periférico. Ante este panorama se impone observar que esta 
"flexibilización" constituye un paso similar al que aconteció cuando el capitalismo aboliendo la esclavitud en su forma clásica posibilitó que el capitalista no tuviese que cargar (en materia de alimentación, salud y habitación) con el "peso muerto" del esclavo improductivo y se limitase a desembolsar recursos vinculados a la efectiva utilización de la fuerza laboral del asalariado en el espaciotiempo de la empresa (que es donde se valoriza el valor personificado por el capitalista). Si en aquella ocasión la modificación se hizo a través de la instauración del contrato de trabajo por jornada o período determinado, la actual "flexibilización" viene a limitar y/o a hacer maleable (para evitar al capitalista los riesgos del desembolso en favor de un asalariado temporalmente "improductivo" en la óptica de la valorización del valor) el período de tiempo considerado.

Así se impone observar que esta situación caracteriza una instancia más de la alienación del asalariado respecto del trabajo (actividad de la que puede apropiarse sólo a través de acciones de éxito incierto y nunca a salvo de las "interrupciones" del desempleo parcial o total).

De ésta eventualidad está relativamente protegido, después y durante el contrato de cuarenta horas semanales el asalariado integrante del Grupo Central; pero nunca está a salvo del despido ni, por ende, del desempleo. Este grupo, al igual que lo que sucede con los otros dos, nada tiene de diferente a lo que hasta aquí habíamos descrito en relación a la alienación padecida por el asalariado respecto de la naturaleza y del otro hombre.

En su situación de supuesto privilegio ni siquiera escapa el integrante de ese grupo a la alienación respecto de la actividad productiva en la medida en que la proclamada flexibilización de horarios y actividades en función de las necesidades de la producción no es otra cosa que la concretización de aquella alienación, una vez que las respectivas decisiones no son fruto de acuerdos consensuales con participación en condiciones de igualdad del interesado, sino mandamientos (precedidos o no de "consultas" a los afectados) del capitalista o sus representantes inmediatos. Como resulta evidente, los integrantes de los otros dos grupos periféricos padecen la misma situación de alienación en el trabajo que los asalariados que hacen parte del Grupo Central, al tiempo que están sometidos de manera más clara, dada la condición precaria de su contrato laboral en materia del tiempo de su duración, a la alienación respecto del trabajo. (Para concluir vale la pena notar que para el análisis aquí realizado el trabajo a domicilio no se singulariza sino por el hecho de que las órdenes y controles del capitalista y/o sus representantes no acompañan al asalariado en el minuto a minuto de su labor; sin embargo ellas no dejan de estar presentes como puntos de partida e instancias de control de calidad 
de la misma vinculadas al pago o no pago del salario estipulado para el "producto patrón" definida por aquél y/o aquellos).

\subsection{El capitalista y el trabajo alienado}

En las condiciones del trabajo alienado vigente en el capitalismo, el capitalista es el "otro hombre extraño" al que son transferidos, en la alienación padecida por el asalariado: a) el producto del proceso de trabajo; b) el objeto e instrumento de trabajo; c) la naturaleza, ex-proveedora de medios de subsistencia inmediata y de medios de trabajo (objeto e instrumento de trabajo); d) la capacidad de trabajo (después que le fue comprada al asalariado); $y$, e) las actividad productiva del asalariado en el espacio-tiempo de la jornada de trabajo.

Cabe preguntarse entonces si el capitalista no hace figura de "hombre realizado", aunque ello acontezca a expensas de la norealización del asalariado. Mas una simple observación de la vida del capitalista es suficiente para que se dude de tal eventualidad. En efecto:

a) El capitalista no desarrolla de sus facultades humanas sino aquellas exigidas por su "función" (para no decir "trabajo") de capitalista; o sea el capitalista está alienado, merced al trabajo alienado vigente en el capitalismo, de las facultades humanas potenciales que su "función" no exige poner en acción; entre ellas podríamos citar la interacción física con la naturaleza a efectos de su transformación orientada a su apropiación y la creación artística;

b) Aquellas facultades que el capitalista pone en acción en su "función", se encuentran rebajadas al carácter de simples medios de subsistencia en cuanto que capitalista y dejan de ser libre exteriorización vital del sujeto que actúa como personificación del capital; así, por ejemplo el capitalista argumentará y aún podrá ejercer la imaginación creadora, pero sólo lo hará en los límites establecidos por la mejor estrategia de valorización del capital que él personifica;

c) Ambas circunstancias significan que el capitalista está alienado de la naturaleza en la medida en que a pesar de ser su propietario y precisamente por serlo el capitalista pierde toda relación transformadora directa con ella a través del trabajo (sin hablar ya de toda relación lúdicoartística, que también pertenece a una facultad específicamente humana);

d) Las dos primeras circunstancias implican una alienación del sujeto que es "soporte" del capitalista respecto de sí mismo y un desarrollo unilateral de las aptitudes que este sujeto, en tanto que humano, posee; este último hecho es la causa 
explicativa de la pasión del capitalista por hobbies diversos que, ocupándolo en las horas libres, no dejan de revelar las vocaciones y actividades de las que se ve castrado por y en su "función" de capitalista;

e) El capitalista se encuentra alienado del otro hombre, lo que se concretiza tanto en la relación conflictiva que mantiene con el asalariado como en la relación competitiva que está condenado a mantener con los otros capitalistas (aunque forme también alternadamente con por lo menos algunos de ellos, como ya lo dijimos, "carteles").

De lo dicho resulta que el capitalista dista mucho de ser el "hombre realizado" que a veces él mismo pretende ser, pour la galerie. Resulta también evidente que la superación de estas características constitutivas de la alienación padecida por el capitalista en situación de trabajo alienado, no puede desvincularse de la superación del propio trabajo alienado en su modalidad capitalista.

\subsection{Los "representantes" del capi- talista y el trabajo alienado}

Llamo "representantes" del capitalista a todos aquellos que operan como mediación directa entre el capitalista y el asalariado en la órbita de la producción como a aquellos que defienden el capitalismo al presentar las relaciones sociales productivas y comunicativas vigentes en el capitalismo como siendo "naturales",las únicas posibles (o, aún, las mejores imaginables con vistas a la "realización" de los seres humanos), ayudando conciente o inconcientemente a su reproducción como régimen social, sin ser ellos mismos capitalistas. Me refiero en el primer caso a los diversos "ejecutivos" que operan en el área de la producción, (entendiendo a ésta en su sentido amplio, o sea incluyendo también la distribución y el intercambio y el consumo productivo) y en el segundo a diversos profesionales entre los cuales quiero destacar los de la red escolar, eclesial, de los medios de comunicación y de la propaganda.

Los primeros, asalariados directos del capitalista, sufren la misma alienación padecida por los funcionarios administrativos, con la salvedad de que ellos son fuente y destinatarios de argumentos en su relación con el capitalista, pero en circunstancias en que esa dinámica argumentativa tiene por límite la palabra final dada siempre por el capitalista en forma de orden, sea esta abierta o "educada". También suelen ser asalariados directos del capitalista (que puede ser el dueño de la agencia de publicidad) los agentes de propaganda. Su situación no difiere de la de los "ejecutivos". Tampoco es diferente de la anterior la situación de los comunicadores y la de los profesores que son asalariados directos de un capitalista (estando contemplados en este último caso los educadores empleados por escuelas privadas).

En un segundo nivel nos encontramos con los religiosos y los 
profesionales de las actividades antes mencionadas pero que no son asalariados directos del capitalista, tal como ocurre con los que se desempeñan en medios públicos. Vale la pena registrar que no por escapar a la relación salarial directa estos profesionales son independientes del capitalista en lo que refiere a la obtención de sus medios de subsistencia. Los religiosos, por ejemplo, dependen de la caridad del capitalista y de las contribuciones ofrecidas por sujetos que son asalariados de los capitalistas, sea directamente, sea indirectamente, por vía del poder político. Los profesionales del servicio público tienen sus medios de subsistencia pendientes del poder político que el capitalista controla. Ello permite concluir que tanto unos como otros son asalariados "sui generis" o indirectos del capitalista.

Por otro lado lo que más me interesa destacar es que tanto unos como otros en y por la "función" desempeñada están tan alienados como el trabajador manual : a) de los objetos e instrumentos de trabajo y de la naturaleza como proveedora de éstos y de medios de subsistencia inmediata, b) de su capacidad laboral vendida, de su actividad laboral (en el espaciotiempo de la jornada de trabajo) así como de sus facultades humanas reducidas a simple medio de subsistencia en el ejercicio de su "función" y de aquellas no exigidas por ésta, c) de sí mismo en cuanto sujeto potencialmente multilateral negado, $y, d$ ) del otro hombre, del que lo separa la competencia cuando es semejante, la conflictividad cuando se trata del capitalista y la indiferencia en ambos casos.

\subsection{El autor de estas líneas y el trabajo alienado}

Lo que acabamos de decir se aplica a los profesores de cualquier nivel de la enseñanza, y dentro de ellos a los docentes de Filosofía. Lejos de sobrevolar la miseria humana con su ciencia, el profesor es un asalariado (directo o indirecto del capitalista) que sólo en los espacios de autonomía, inestables y de fronteras no siempre claras, vigentes en la enseñanza (en particular, como fruto de la lucha sindical de los docentes) puede alzar la voz para ejercer la crítica del capitalismo. Sin embargo nunca está libre de un achicamiento o simple eliminación de esos espacios (por ejemplo como consecuencia de un golpe de Estado o de la decisión de un jerarca) que no sólo pone punto final a su crítica, sino que también pone en jaque su "libertad" $y$, a veces, hasta su vida.

El profesor, también el de filosofía, es un ser humano carente de objeto e instrumentos de trabajo, alienado de la naturaleza en tanto que proveedora de tales y de medios de subsistencia inmediata, que se ve obligado a hacer de sus capacidad laboral un medio de subsistencia individual desplegado en una actividad en la que, por su control exógeno, su rutina y horarios 
prolongados (a los que se agrega a veces el soberbio desinterés de los alumnos, o aún la estresante "bataIla campal" entablada con éstos), "no se siente feliz sino desgraciado" y de la que "tan pronto no existe una coacción física o de cualquier otro tipo...huye...como de la peste" (Marx 1844, I ).

El profesor, también el de filosofía, es un hombre unilateralmente desarrollado en sus capacidades humanas, de vida libresca, ignorante muchas veces tanto de los "secretos" de la instalación eléctrica que le permite leer por la noche como de los actos que traen un tomate desde la semilla hasta su mesa; ello porque, así como el trabajo manual reduce al trabajador que lo practica a una mano (¡de hecho, de él se habla Ilamándolo "mano de obra"!), el trabajo intelectual practicado por el profesor lo reduce a la condición de cabeza desvinculada del cuerpo y las prácticas necesarias al logro de los medios que al permitir la subsistencia de éste último son condición del ejercicio de la actividad de aquella. Aquí se consuma la alienación del profesor respecto de la naturaleza, por el hecho de no participar directamente en la acción transformadora que hace posible su apropiación por la especie humana. No raramente esta distancia respecto de la naturaleza, cuando no el sueño frustrado por la división social del trabajo vigente en el capitalismo de ser agricultor, se revelan, ocultándose, en la fruición con la que el profesor cultiva y disfruta un minúsculo jardín de fondo de casa o de balcón de apartamento. Otras, aquella distancia y esta vez el sueño frustrado del ingeniero, del mecánico o del carpintero hacen del profesor el infatigable "bricoleur" de las horas libres ante el cual desfilan todas las cosas rotas de la casa.

Pero una y otra actividad no pasan de ser simples intervalos, siempre demasiado cortos, en la actividad en la que se ve obligado a volcar lo mejor de sus energías; aquella que siendo propia a su "función" de profesor, no es escenario del despliegue de "una libre energía física y espiritual", no es "trabajo... voluntario, sino forzado, trabajo forzado". (Marx, 1844, I, la cursiva es de Marx). El profesor es también como asalariado, y cualquiera que sea su nivel de actividad, un ser humano acechado por el desempleo, compelido a velar en situación conflictiva por el valor de su salario y sometido a la competencia con sus semejantes. Sólo la falta de reflexión sobre su condición vital como el autoconvencimiento provocado por el papel de "omnipotente dueño del saber" que a veces el profesor representa ante sus alumnos, pueden hacerlo ajeno a estas simples verdades. 


\section{Nuestro resumen sobre la violación de las tres normas fundamentales de la ética en el capitalismo}

11.1. La violación de las dos primeras normas de la ética

n la medida en que en esa célula fundamental del trabajo alienado en el capitalismo que es la empresa, el trabajador está siempre sometido a las órdenes del capitalista (ordenes cuya "felicidad" el asalariado debe reconocer siempre so pena de perder su empleo), es evidente que el día a día del capitalismo niega al asalariado el ejercicio da su libertad individual de decisión y su participación en la construcción de propuestas consensuadas. En el capitalismo se espera del trabajador, lo mismo que del soldado, o sea, que no piense, sino que obedezca. Como dijo Marx, en el contexto del trabajo alienado el asalariado pasa a ser una "cosa" más (como lo son el instrumento y el objeto de trabajo) perteneciente al capitalista; y el capitalista cree estar en lo cierto cuando concluye que esa "cosa" como cualquier otra está incapacitada para la libertad de decisión que es amparada por la primera norma de la ética.

El capitalismo es una orden social de "guerra de todos contra todos"; guerra de capitalistas contra capitalistas (aunque se alíen contra los asalariados y puedan aliarse entre sí en carteles para guerrear contra otros carteles); guerra de los capitalistas contra los asalariados (en especial a causa del monto del salario, de las condiciones del trabajo y de la duración de la jornada do trabajo); y guerra de asalariados contra asalariados (en particular en la lucha por la conquista y manutención del empleo). En esas circunstancias es evidente que estamos muy lejos de la construcción consensual de respuestas exigidas por la segunda norma de la ética.

Al mismo tiempo esa guerra se acompaña de la indiferencia creciente de cada ser humano para con los otros en el egoísmo creciente que el capitalismo causa e incentiva al glorificar la competencia. Hoy hay pesquisas que muestran que el crecimiento de esa indiferencia acompaña al desarrollo capitalista; así, un actor que finge sentirse mal en la calle, es atendido por casi todos en la pequeña ciudad (de capitalismo comercial incipiente y rodeada de un campo donde todavía hay ecos de vivencias precapitalistas), es atendido por pocos en la ciudad media (la del comercio y la industria medianos), y por casi nadie en la gran urbe (centro del gran capital financiero, comercial e industrial).

\subsection{La violación de la tercera norma de la ética}

Los efectos nocivos para la naturaleza, resultantes de la conti- 
nuidad del modelo de produccióndistribución-consumo imperante hoy en día, provocan una degradación cuantitativa y/o cualitativa de tal magnitud en el medio ambiente que hace posible la vida humana, que la propia subsistencia de la humanidad corre peligro. Ese peligro es reconocido incluso en foros tan marcados por a influencia directa de los grandes capitales como lo es el "Club de Roma". La amenaza de un holocausto ecológico capaz de exterminar la humanidad entera es una situación absolutamente inédita en la historia de la especie humana.

Ahora bien, aquí quiero destacar en primer lugar que la incertidumbre en relación a la obtención y manutención del empleo, el nivel de exigencia en la actividad productiva y los peligros existentes en ella (velocidad de la línea de producción, y/o nivel de tensión-atención permanente, $y / o$ falta de equipos $y$ medidas de seguridad) y los efectos contaminantes de la producción capitalista llevan literalmente a los asalariados a enfermarse. Diversas pesquisas muestran el estrago que en las masas asalariadas causan los accidentes de trabajo (muchas veces mortales, en especial en las industrias de la construcción y del transporte), las enfermedades diversas causadas por la contaminación de la tierra, el agua y el aire (hecho evidenciado en la correlación existente entre la mayor mortalidad por problemas circulatorios/ respiratorios en una misma ciudad como São Paulo y el mayor nivel de contaminación del aire que allí se respira), y las enfermedades físicas y/u mentales debidas al estrés. Una y otra evidencia son contrarias a la salud de la naturaleza humana en el contexto del trabajo alienado capitalista, y por eso son contrarias a la tercera norma ética.

En lo que respecta a la salud de la naturaleza no-humana, son hoy ya indiscutibles los estragos que le causa la producción-distribuciónconsumo capitalista basada en el trabajo alienado. A tal punto, como dijimos, que el envenenamiento progresivo de la tierra, del aire y del agua, hace peligrar la supervivencia futura de la propia especie humana (por lo menos en las áreas más contaminadas). Al mismo tiempo se verifica una clara devastación del espacio geográfico: deforestación irreversible (hoy especialmente en las grandes florestas tropicales), desertificación y salinización de inmensas áreas a causa de usos agrícolas no sustentables, uso insostenible de recursos minerales y energéticos no renovables (todo indica que el petróleo se acabará antes del siglo XXII), y la mismísima agua potable ya empieza a faltar en muchos países o regiones de países. Si el ciclo del agua ya está afectado a ese punto, no menos afectado lo está el ciclo del carbono, porque emisiones masivas derivadas del modo capitalista de produccióndistribución-consumo (copiado antes por el Ilamado "socialismo real" difunto en Europa desde 1991) generaron el "efecto invernadero" 
que está alterando el clima mundial a causa de un calentamiento de la temperatura en el planeta (con el derretimiento de los hielos polares y el consecuente aumento del nivel de los océanos y variación de corrientes marinas, cuyos efectos son todavía incalculables en detaIle); otros gases generados por la producción-distribución-consumo capitalista aumentan el agujero en la capa de ozono, lo que se traduce en un aumento de la radiación ultravioleta que alcanza la superficie terrestre (con los peligros que ello conlleva, como el aumento de los cánceres de piel, ya detectado en el sur de Brasil); al mismo tiempo la producción-distribución-consumo capitalista ponen en riesgo de extinción cada día a más y más especies vegetales e animales.

\subsubsection{Buscando explicaciones}

En la búsqueda de la explicación de por qué el capitalismo viola la tercera norma de la ética hemos propuesto dos hipótesis.

-La hipótesis marxiana: Time is Money

Marx mostró (en especial, en el segundo volumen de El capital, al analizar los efectos de la velocidad de rotación del capital) que la búsqueda de la maximización de la ganancia es una obligación que se impone a cada capital(capitalista) si quiere sobrevivir como capital (capitalista) en la competencia impie- dosa con otros capitales (capitalistas); si de dos capitales de la misma rama con igual magnitud, uno de ellos obtuviese el doble de plusvalía que otro en el mismo tiempo, en la medida en que el primero invirtiese parte de esa diferencia en innovaciones tecnológicas (que el segundo no tendría) que le permitiesen producir su producto por debajo do su valor, en poco tiempo, vendiendo su producto más barato que su competidor, estaría expulsándolo del mercado ( $y$, de hecho, aniquilándolo como capital/capitalista). Marx mostró que en esa dinámica hay una presión que obliga a cada capital (capitalista) a aumentar sin cesar su velocidad de rotación para no perecer $y$, si es posible, quedarse solo, ocupando todo el espacio, expulsando a los competidores (ver El capital, T. 2, S. 1, cap. IV, y S. 2, caps. VII, IX y XIII). Por nuestra parte (coincidiendo, sin saberlo, con otras interpretaciones), dedujimos de ese hecho la conclusión de que la devastación de la naturaleza (humana y no humana) acontece en el capitalismo porque la velocidad creciente con la que el capital usa de esos recursos para valorizarse, es menor que el 'tiempo de recuperación' que la naturaleza humana y no humana necesitaría para preservarseregenerarse en equilibrio dinámico. (López Velasco 2003 b, p. 69-79; ver también O'Connor 1990a y 1990b, sobre la segunda contradicción del capitalismo). 


\section{La superación de la alienación: Comunismo y ecomunitarismo}

E n los Manuscritos de 1844, Marx caracterizó resumidamente el comunismo como "retorno del hombre para sí en cuanto ser social, es decir, humano; retorno pleno, consciente y efectuado dentro de toda la riqueza de la evolución humana hasta el presente. Este comunismo es, como completo naturalismo, humanismo y, como completo humanismo, naturalismo; es la verdadera solución del conflicto entre el hombre y la naturaleza, entre el hombre y el hombre, la solución definitiva del litigio entre existencia y esencia, entre objetivación y autoafirmación, entre libertad y necesidad, entre individuo y género. Es el enigma resuelto de la historia y sabe que es la solución" (III 143).

Al fin del primer tomo de $E I$ capital (que, recordémoslo otra vez, fue el único que Marx logró publicar en vida) nuestro autor presenta el paso al comunismo como sigue: "El monopolio del capital se convierte en grillete del régimen de producción que ha crecido con él y bajo él. La centralización de los medios de producción y la socialización del trabajo llegan a un punto en que se hacen incompatibles con su envoltura capitalista. Esta salta hecha añicos. Ha sonado la hora final de la propiedad capitalista. Los expropiadores son expropiados. El sistema de apropiación capitalista que brota del régimen capitalista de producción, y por tanto, la propiedad privada capitalista, es la primera negación de la propiedad privada individual, basada en el propio trabajo. Pero la producción capitalista engendra, con la fuerza inexorable de un proceso natural, su negación. Es la negación de la negación. Esta no restaura la propiedad privada ya destruida, sino una propiedad individual que recoge los progresos de la era capitalista: una propiedad individual basada en la cooperación de trabajadores libres, y en la posesión colectiva de la tierra y de los medios de producción producido por el propio trabajo". Y Marx remataba: "La transformación de la propiedad privada dispersa y basada en el trabajo personal del individuo en propiedad privada capitalista fue, naturalmente, un proceso muchísimo más lento, más duro y más difícil, que será la transformación de la propiedad capitalista, que en realidad descansa ya sobre métodos sociales de producción, en propiedad social. Allí se trataba de la expropiación de la masa del pueblo por unos cuantos usurpadores; aquí, de la expropiación de unos cuantos usurpadores por la masa del pueblo".(I 699-700, hemos corregido la traducción cotejándola con el original alemán).[Nótese que en esta ocasión Marx no usa la palabra "comunismo", aunque sin duda se 
refiere a la transformación que conduce hacia él].

Hay que notar que en la primera edición del primer tomo de El capital (cuya versión fue después sustituida por las ulteriores supervisionadas por Marx y por las ediciones 'canónicas' a cargo de las autoridades soviéticas y alemanas), Marx decía en este pasaje: "El modo de producción y apropiación capitalista y por tanto la propiedad privada capitalista es la primera negación de la propiedad privada individual basada en el propio trabajo. La negación de la producción capitalista se producirá por sí misma con al necesidad de un proceso natural. Es la negación de la negación. Ella muestra de nuevo la propiedad individual, pero sobre la base de los avances de la era capitalista, la cooperación de trabajadores libres y su apropiación colectiva de la tierra y de los medios de producción producidos a través de su propio trabajo" (Traducción nuestra, a partir de la edición alemana, p. 705-706).

PO destaca como en El capital Marx sostiene que, desde el punto de vista productivo "la libertad tienen una dimensión específica cuando se identifica con el 'desarrollo de las fuerzas productivas como fin en sí mismo, y que ese sería el verdadero 'reino de la libertad'" (PO, p. 168). Por nuestra parte, subrayamos que si bien el ejercicio por sí mismo de la capacidad creadora es, sin duda, desalienante (como lo hace el artista que no produce en/para el mercado), cuando se extiende ese 'por sí mismo' al conjunto de la producción, hoy se imponen límites que la tercera norma de la ética ayuda a trazar. Recordemos que en El capital, Marx nos dice que el reino de los productores libres libremente asociados aún no es el 'reino de la libertad', pues, situada aún en el 'reino de la necesidad', hace posible una única libertad, la de que aquellos productores "regulen racionalmente ese metabolismo suyo con la naturaleza poniéndolo bajo su control efectivo, en vez de ser dominados por él como por un poder ciego y que lo lleven a cabo con el mínimo empleo de fuerzas y bajo las condiciones más dignas y adecuadas a su naturaleza humana" (T. III, citado por PO, p. 270). PO destaca (refiriéndose a los Grundrisse, pero podemos aplicarlo también a El capital) que Marx postula "la libertad del hombre real como meta fundamental del comunismo y que sólo será posible como resultado histórico" (PO, p. 283).

Sabedores por la experiencia histórica de que el paso al comunismo no es ni será tan "inexorable", ni tan "natural", ni tan "fácil" como lo creyó Marx, pero ampliandoprecisando-actualizando la utopía marxiana a las esferas comunicativa, pedagógica, ecológica, erótica y política, hemos propuesto el ecomunitarismo.

Llamo "Ecomunitarismo" al orden utópico poscapitalista (nunca alcanzable, pero indispensable horizonte histórico, guía de la acción) capaz de articularse en base a las 
tres normas de la Ética, y de mantenerse mediante la postura de seres humanos en actitud de liberación.

El ecomunitarismo, en su dimensión productivo-distributiva, comunicativa, ecológica, pedagógica, política y erótica, retoma, actualizándola y completándola, la utopía marxiana del comunismo (ver López Velasco 1996, cap. VIII).

\subsection{No-trabajo, género y necesi- dades humanas, ciencias y "orden" en el Ecomunitarismo}

Si el "trabajo" ejecutado-padecido en el capitalismo es actividad productiva alienada, por su modalidad clasista-asalariada, que, sometida al imperio de la "orden", es el tormento diario del que se huye como de la peste tan pronto como surge la oportunidad, el No-Trabajo al que apostamos en el ecomunitarismo es lo contrario de todo eso.

El No-trabajo es la instancia de expresión libre de las energías productivas en la cual las personas realizan alternadamente sus múltiples vocaciones. El tiempo diario y total de la faena será el mínimo posible, según lo exija la satisfacción de las necesidades comunitarias, y es de suponer que el mismo habrá de tender a cero (en especial gracias a los procesos de automación y la equitativa distribución de las labores. [Terminado ese lapso de tiempo, comienza el uso absolutamente libre, por decisión individual, de cada día y de la vida toda, para lo que se quiera, incluido el ocio].

En él, el desarrollo universal de los individuos es universal no sólo porque cada individuo se desarrolla multifacéticamente a partir de sus vocaciones (respetadas las exigencias puestas por las normas éticas), sino también porque ese proceso se realiza en y gracias a la interacción consciente existente entre cada individuo y el resto de los seres humanos a través del contacto de sus respectivas comunidades de vida.

Así se completa, en la negación de su actual existencia restricta en tanto no-consciente en el capitalismo, la aparición y perpetuación de individuos que producen su vida en interacción con el conjunto de los seres humanos. O sea, así se constituye el género humano como entidad real.

A partir del plano productivo local de cada comunidad y abarcando sistémicamente lo regional y lo planetario, se establece esa interacción universal consciente de los individuos.

Apoyados en ese plano y desbordándolo, se articula el conjunto de los intercambios individuales universales que no se caracterizan o no se caracterizan solamente como "productivos", por abarcar aspectos vinculados, por ejemplo, a la creación estética o a las relaciones de amistad.

Ambas dimensiones de esa interacción son ya hoy, desde el punto de vista técnico, perfectamente realizables, in situ y a distancia, en especial a través de los medios de transporte intercontinentales (cuyos actuales efectos contaminantes deberán ser eliminados), como por las 
redes electrónicas y "multimedia" de comunicación.

Aclaremos lo que catalogamos como "necesidades" puestas y resueltas por y en el desarrollo de los individuos universales.

A veces esta cuestión ha sido abordada en base a una supuesta diferencia existente entre "necesidades legítimas" y "necesidades artificiales" (o sea, "falsas necesidades") humanas.

Es evidente que la realidad del "consumismo capitalista" proporciona un cierto contenido pertinente a lo que parece designarse con las palabras "necesidades artificiales". (El mismo Marx hizo uso de expresiones parecidas al tratar de la dinámica de produccióndistribución-consumo vigente en la sociedad capitalista). Mas, cuando se pretende profundizar el análisis, la diferencia establecida se revela problemática bajo dos aspectos:

a) La "legitimidad" de ciertas necesidades a veces se interpreta, en oposición a lo "artificial", como siendo "natural", y,

b) Esa diferencia supone un fundamento ético a partir del cual pueda afirmar su pertinencia.

En relación al primer aspecto hay que notar que el ser humano es precisamente aquella parte de la naturaleza que a través de la cultura transforma su naturaleza; dicho de otro modo, la especie humana es la parte de la naturaleza que se encuentra, en y a través de su deve- nir histórico, en permanente estado de auto-producción. De ahí que hablar de una "necesidad natural", refiriéndose a los seres humanos sea incurrir en una equivocada visión inmovilista que contradice el carácter históricamente autopoiético de la especie humana; falsedad que se aproxima de un non-sens.

En lo referente al segundo punto, hago notar, además de la ausencia de todo fundamento ético explícito en Marx al aludir a la mencionada diferencia, que la cuestión de la "necesidad legítima" sólo puede ser encuadrada y resuelta a partir de las tres normas éticas trascendentalmente deducidas por nosotros anteriormente.

Ahora, obsérvese que las mismas no establecen una versión estática de cuales son las "necesidades" que caben en sus límites y, al hacerlo, cobran "legitimidad" ; al contrario, aquellas normas se comportan como fronteras flexibles en cuyo seno puede ser acogida como "necesidad legítima" toda carencia puesta por el desarrollo universal de los individuos que no transgreda la libre deliberación consensual con los otros y que no contraríe la preservación de una naturaleza sana desde el punto de vista productivo.

El entendimiento entre los seres humanos y el desarrollo de la tecnología ecológicamente sustentable son los mecanismos que en cada momento histórico habrán de marcar los límites de lo que cabe admitir como "necesidad legítima" 
a ser atendida por y en la vida ecomunitarista.

Ahora bien: ¿cómo conciliar las vocaciones diversas con el conjunto de necesidades comunitarias que deben ser satisfechas en cierto nivel ya alcanzado (y que nunca cesa de ser mejorado, si no cuantitativamente, por lo menos cualitativamente)?

La respuesta es: a través del acuerdo consensual de los productores libremente asociados que contraen y renuevan periódicamente su pacto de convivencia.

Una vez establecida la lista de necesidades y aquella de las disponibilidades vocacionales, el acuerdo comunitario de no-trabajo (establecido consensualmente y con todos los recursos computacionales necesarios) es el mecanismo de compatibilización entre ambas.

Ese acuerdo tanto en lo relativo al tipo como al tiempo rotativo de actividad, tiene por base la comunidad local (el distrito), pero se integra a los macro-acuerdos que abarcan sucesiva y sistémicamente espacios mayores, hasta culminar en el planeta entero (y más allá, en los lugares extraterrestres donde haya, provisoria o definitivamente, seres humanos residentes). Ese acuerdo planetario renovado periódicamente viene a sustituir la actual división mundial del trabajo, generada de forma a-consensual y aleatoriamente a través de las Bolsas que se alternan para operar las veinticuatro horas del día. Notemos que MM había notado que para que se haga posi- ble la realización plena de la truncada racionalidad tecnológica vigente en el capitalismo, o sea "para que la transparencias del sistema productivo y con ella la posibilidad de una real planificación se den, es preciso, pues, que el conocimiento del aparato productivo sea un hecho de comunicación social general"; y remata "La idea de una autoridad planificadora sobre una sociedad atomizada es, además de siniestra, utópica" (p. 139); y luego registra que aquella planificación participativa "sólo puede cumplirse en una situación política de democracia sin restricciones" (p. 149); finalmente, con Marx, MM destacará que "la forma política de la dictadura del proletariado es la república democrática" (p. 166). Por nuestra parte resaltamos que esas formulaciones de MM representan exactamente la aplicación de la primera y de la segunda norma de la ética (acompañadas de la tercera, en lo que tiene que ver con la precaución ecológica por la vida humana y no humana, y por los sistemas abióticos del planeta en general) a la esfera del notrabajo (de las relaciones sociales, en general) en el ecomunitarismo.

AA nota que en el capitalismo se verifica "la autoenajenación que experimenta el individuo como ser necesitado, la alienación de sus necesidades, lo mismo individuales que colectivas" (p. 294); y aclara: "Por alienación de las necesidades, pues, ha de entenderse en general la determinación formal capitalista de aquéllas en la medida en que 
induzca la supeditación de las necesidades materiales a las necesidades formales, la supresión, deformación o limitación de las necesidades en virtud de aqueIla forma social" (p. 297). Como nosotros AA destaca que no cabe distinguir abstractamente entre necesidades naturales y artificiales ( $p$. 295). Ahora bien, para resolver el problema de las necesidades a las que no corresponden vocaciones, creo que dos son los caminos: la distribución equitativa de la carga indeseada mediante faena rotativa y la invención, mediante tecnología ecológicamente sustentable, de modalidades productivas que prescindan de la participación humana.

MM notó que "el proletariado está, en efecto, esencialmente marcado por la 'esencia de la técnica'. Burguesía y proletariado son, en efecto, predicados del mismo sujeto, o sea: aspectos de la misma única estructura, la cual sólo puede ser entendida como totalidad. Si Marx atribuye a 'la burguesía' la transformación técnica del mundo, ello podría ser una descripción de la fase inicial de esa transformación, pero también puede ser (y nosotros preferimos suponer que así es) una tesis más esencial, si por 'la burguesía' se entiende 'la sociedad burguesa', esto es: el modo de producción moderno, ya que el proletariado mismo sólo existe en la medida en que ese modo de producción se mantiene de alguna manera, y esto quiere decir: inclusive durante todo el proceso histórico-mundial de la trans- formación revolucionaria que Marx ve como posibilidad" (p. 96). Luego dirá MM que para Marx "la revolución es la única posible 'conservación' de la sociedad moderna, y, por lo tanto, el único posible cumplimiento de la propia 'revolución burguesa'" (p. 153). Por nuestra parte hacemos nuestra esta observación para destacar que (a diferencia de algunas propuestas 'verdes' antitecnológicas) el ecomunitarismo supone la superación-conservación (aufhebung) de la técnica desplegada por el capitalismo, pero/y: a) poniéndola al servicio del desarrollo universal de todos los individuos, b) adaptándola-limitándola al cuidado ecológico prescrito por la tercera norma de la ética, y, c) renunciando en una libre auto-censura a toda ciencia y técnica que violen cualquiera de las tres normas éticas y/o se contrapongan a la aspiración del libre desarrollo universal y solidario de todos los individuos en un contexto de preservación-regeneración permanente de la salud de la naturaleza humana y no humana.

Nótese que si las ciencias éticamente fundamentadas (y si es preciso autocensuradas) y con responsabilidad ecológica son un pilar del No-trabajo, como se puede imaginar a la luz de lo que ya fue dicho, el cultivo de las ciencias no será en el ecomunitarismo asunto de una "comunidad científica" como la existente en el capitalismo; es ahora una entre otras de las diversas actividades que una persona puede desarrollar en alternancia tempo- 
ral con vistas a su libre expansión multilateral. Así se resuelve la unilateralización, que es sinónimo de pobreza humana, de los actuales científicos, al tiempo que se acorta la distancia, por disolución de la actual comunidad compartimentada en el tejido social, entre los practicantes y los no practicantes de actividades caracterizadas como científicas, siendo que estos últimos, sobre la base de una instrucción generalizada, tienden a desaparecer.

La dinámica "acuerdista" aquí descrita supone la eliminación de la "orden" del universo productivo (y social en general) y su sustitución por Casi-RazonamientosCausales (CRC) que establecen las obligaciones asumidas y operan en un contexto donde todo cargo de coordinación-fiscalización es electivo y rotativo.

Ante la supuesta transgresión de lo consensualmente establecido por parte de alguno de los participantes, el CRC de "segundo grado" con que lo interpela un partner (ocupe o no éste algún cargo de coordinaciónfiscalización) o el conjunto de los partners tiene la siguiente forma: "(Debes) procede(r) de la forma ' $y$ ' porque ' $z$ ' fue lo acordado".

El interpelado, en función de la gramática de los CRC, aceptará el obligativo que da inicio al CRC de segundo grado si asume como verdadero el enunciado " $z$ ".

Si no lo considera verdadero entonces habrá que recurrir a instancias que puedan resolver la duda, por ejemplo al testimonio de otros participantes y/o documentos que revelen los términos de lo acordado previamente.

De ese recurso resultan dos finales posibles: o es confirmada la veracidad del enunciado "z" y el transgresor queda sujeto al obligativo que aquel enunciado justifica, o el enunciado " $z$ " resulta falseado y queda derogado el obligativo en cuestión, al tiempo que se concluye que la supuesta transgresión no tuvo lugar. [Al que le parezca engorroso este procedimiento le recuerdo que el mismo ya funciona cotidianamente en las "reglas" establecidas en los juegos de niños por los propios participantes).

En lo que respecta a la división comunitaria del producto y los servicios del No-Trabajo, el ecomunitarismo se ajusta al lema "De cada uno según su capacidad, a cada uno según su necesidad" (recordando que ésta última está sometida al tamiz de las tres normas éticas). Una vez obtenidos los productos y servicios comunitariamente, su distribución también se hará comunitariamente. Un acuerdo semejante al "pacto de producción" establece el "pacto de distribución", que es cronológicamente anterior al primero en la medida en que lo orienta en cantidad y calidad. El salario y el dinero han desaparecido de la historia humana y las necesidades individuales (a través de la familia, en la forma de ésta que venga a subsistir, o directamente) son satisfechas a partir del "fondo económico 
comunitario". Nótese que en este modo de producción-distribución, también es atendido en sus necesidades legítimas (establecidas, como para cualquiera a partir de las tres normas fundamentales de la ética), el "ex capitalista" (y su familia), devenido ahora, y tras haber sido liberado de su "función" de capitalista" un miembro más de la asociación libre de productores libres; en eso llevamos en serio (como lo hizo él), la satírica observación de Marx cuando, comentando la opinión de Courcelle-Seneuil de que 'la conservación de un capital supone un esfuerzo constante para resistir la tentación de devorarlo', respondía: "El más elemental sentimiento de humanidad ordena, pues, indudablemente, redimir al capitalista de ese martirio y de esa tentación, del mismo modo que la reciente abolición de la esclavitud ha venido a redimir al esclavista georgiano de la trágica disyuntiva de si había de gastarse en champán toda la ganancia arrancada a latigazos a los esclavos negros, o invertir una parte para comprar más negros y más tierra" (T. 1, L. 1, S. 7, cap.XXII, p. 543).

Para finalizar este tópico, notemos que MM considera "problemática fórmula" la usada por Marx al usar el eslogan "A cada uno según sus necesidades" (p. 168 y ss). MM registra que Marx subrayó que la mercancía "satisface necesidades humana de una u otra índole", y, por otro lado, que el valor de la fuerza de trabajo está determinado por las "necesidades" del traba- jador, o sea, por las necesidades cuya satisfacción es necesaria para la existencia y conservación de la fuerza de trabajo. Y MM sostiene que esos dos conceptos de "necesidad" no pueden ser lo mismo; el segundo remite a la mera "subsistencia" (como fuerza laboral), y no merece, dice MM, el adjetivo "humano". Por nuestra parte diremos que en la fórmula usada por Marx, "de cada uno según su capacidad y a cada uno según su necesidad", que recuperamos en la propuesta ecomunitarista, la "necesidad" aquí retenida remite a todas las carencias individualmente diferentes, que deben ser satisfechas para que cada individuo se desarrolle (en cooperación solidaria con los otros, y en cuidado preservadorregenerador de la salud humana y de la naturaleza no humana) como individuo universal, según las diversas vocaciones que son las suyas (y cuya actualización no contraríe ninguna de las tres normas éticas fundamentales). MM dice que tal enfoque, presente en Marx, pertenece a uno de los conceptos-límite en el análisis marxiano de la sociedad moderna, y destaca que si se satisface toda necesidad, el propio contenido de la 'necesidad' desaparece (p. 174). No negamos esa visión de los hechos, pero creemos que esa superación de la oposición necesidad-satisfacción merece figurar, por su claridad (aunque difusa, como tiene que ser en una Historia nunca acabada de "necesidades" que se definen y redefinen sin cesar 
a la luz de la ética), en la bandera ecomunitarista.

Por otro lado MM observa (en perfecta sincronía con nuestra visión abierta de las "necesidades" históricamente renovables en permanencia, a partir del uso de la libertad de decisión que exigeampara la primera norma de la ética) que un ser humano puede optar libremente por no comer, eligiendo así la muerte. Pero MM quizá va demasiado lejos cuando infiere de ahí, en óptica condenatoria de toda "presuposición esencialista acerca de 'el hombre'", que haya que excluir "toda afirmación (explícita o implícita) según la cual haya un cierto fin que convierta en 'necesidades necesarias' los medios necesarios para él" (p. 170). Creemos que para el ser humano que decide vivir, su condición de mamífero (sin duda diferente, pero no menos similar en muchos aspectos a otros) plantea una serie de necesidades como condiciones de posibilidad de su subsistencia física, y mucho más allá de ella, en óptica ecomunitarista, de su realización como individuo universal; de allí las reivindicaciones-propuestas ecomunitaristas (basadas en Marx) en materia de alimentación, salud, vivienda, educación, equipos, recursos técnicos, esparcimiento, etc. Igual posición a la nuestra sobre la preservación de la categoría de "naturaleza humana" en el Marx maduro, incluso en El capital, es la que defiende Arteta (en especial AA, p. 270-271 y p. 280).

\subsection{Ecomunitarismo, ecología, pedagogía ambiental y erótica.}

Basado en la tercera norma de la ética [Debo preservar-regenerar una naturaleza sana desde el punto de vista productivo porque yo preservo-regenero una naturaleza sana desde el punto de vista productivo es condición de Yo hago la pregunta' ¿Qué debo hacer?'] el comportamiento ecomunitarista respecto de la naturaleza no-humana tendrá un carácter preservador-regenerador.

En términos concretos eso significa que la producción ecomunitarista reposa al máximo sobre recursos renovables, de forma a economizar lo más posible los recursos no-renovables, adaptándose al principio de las "Cinco $R^{\prime \prime}$ que prescribe la reflexión, rechazo, reducción, reutilización y reciclaje de los residuos, y preocupada por evitar la contaminación, admitiéndola provisoriamente sólo cuando es reversible.

Esa conducta será tema fundamental de la educación problematizadora que en las instancias formales, no-formales e informales, habrá de caracterizar el panorama cultural-educativo del ecomunitarismo.

La teoría de tal educación se encuentra en Paulo Freire (1970, cap. II), donde la práctica pedagógica que él Ilamo "problematizadora" (contrapuesta a la "bancaria", cómplice de la dominación), puede resumirse, incorporando mi pers- 
pectiva ética, en el siguiente modelo sistémico cualitativo:

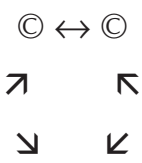

(R)

En donde (C) representa a cada uno de los sujetos en la interacción pedagógico-dialógica que hace parte del proceso de "conscientización" y â representa al referente, o sea, el "objeto" a propósito del cual los primeros están construyendo conocimiento. Nótese que dicho referente no se limita a la clase de los objetos físicos, pudiendo ser también, por ejemplo, como "objeto" de conocimiento, el tipo de relaciones que unen-desunen a los sujetos en cuestión y aquél que éstos tienen con la naturaleza que los cerca.

Ese conocimiento a propósito del referente no será más que la serie de los consensos a los cuales los sujetos dialogantes pueden llegar sobre la base del ejercicio de la libertad individual de convicción y postura, que se enriquece con el develamiento crítico progresivo del referente. [Y cuando se dice "progresivo" no se entienda tal característica como siendo sinónimo de una acumulación sumatoria no-contradictoria, sino como proceso sometido a crisis de renovación, incluso de los fundamentos, como las descritas por Thomas Kuhn (Kuhn 1962)].

Ahora bien, Freire situó la construcción del conocimiento al interior de la "praxis ", que él definió como "a reflexão e ação dos homens sobre o mundo para transformá-lo". Por tanto, como la relación al referente no es solamente teórica, sino también práctico-transformadora, resulta que no sólo se transforman las opiniones de los sujetos acerca del referente, sino que también cambia el propio referente.

$\mathrm{Y}$ el cambio del referente no dejará de influenciar a los sujetos cognoscentes y a sus sucesores, al interior de una interacción de tipo "sistémico", pero histórica. [De ahí la flecha doble que en el modelo arriba citado parte tanto de los sujetos rumbo al referente, como de este último hacia los sujetos].

Sobre esa base se abre la perspectiva de superar la visión "utilitarista" presente en la tercera norma de la ética, para, en el marco del desarrollo multifacético de los individuos, incentivarse y posibilitarse el re-encuentro lúdico-estético de los seres humanos con toda la naturaleza.

Ese cambio, fundamentado en la tercera norma ecológica, pero que abre una perspectiva que la supera solamente es posible en el contexto del ecomunitarismo, donde la naturaleza no-humana ha sido desprivatizada y el ser humano ha superado la alienación en relación a sí mismo y en relación a los otros seres humanos.

En el campo de la erótica destacamos que la primera norma de la 
ética ampara el autoerotismo de la masturbación, que debe ser desculpabilizada (en particular en la fase de maduración sexual de la pubertad y la adolescencia, pero también en la fase adulta, en situaciones ocasionales), superándose así las conductas alienadas de auto-represión y represión que causan grandes y duraderos traumas. La segunda norma ampara por igual tanto a las parejas homosexuales como a las heterosexuales, pues lo que la ética exige es el consenso en el placer compartido, sin importar el sexo de los participantes. No obstante, esa misma norma condena la relación sexual con cualquier sujeto que transitoria o durablemente esté incapacitado para ejercer la libertad de decisión exigida por la primera norma (tal es el caso de los niños, los animales y las personas bajo efecto de drogas o del alcohol consumido en cantidad excesiva). La tercera norma, reforzando la segunda y la primera, ampara toda conducta que, querida por los participantes, redunde en su bienestar (y por ende en su salud física y mental). La primera norma ampara la decisión de no procrear y por tanto los métodos anticonceptivos, bastando la opción de uno de los participantes para legitimarlos. Por último nótese que la ética no ampara el aborto, pues tal práctica significa retirar del futuro adulto que es el embrión o feto, la libertad de decisión que le reserva la primera norma para opinar sobre su existencia o no existencia. (De manera menos rigurosa aquí me mueve el siguiente razonamiento: porque no me agrada la idea de que pudieran haber prescindido de mi existencia sin consultarme, no me siento con derecho de quitarle la existencia a un ser humano que aún es incapaz de opinar; nótese que el debate sobre "cuando empieza la vida" para autorizar el aborto está superado por la descripción del genoma humano, que determina, ya a partir de la fecundación, el carácter humano del nuevo ser).

\subsection{Ecomunitarismo y ciencias: ¿queremos todo lo que podemos?}

La ciencia y la tecnología son instrumentos fundamentales de aquello que podemos hacer, también en perspectiva ecomunitarista. Pero, ¿debemos querer hacer todo aquello que nos permiten hacer la ciencia y la tecnología? Los desastres y las amenazas socioambientales vinculadas a ciertas investigaciones y realizaciones científico-tecnológicas han Ilevado al ecofeminismo a declarar que la ciencia es mecanismo opresordevastador de mujeres y niños (en especial en el Tercer Mundo) y de la naturaleza no humana. Así Mies y Shiva (1997) sostienen que la ciencia occidental se apoya en las relaciones de violencia patriarcal (que cobran forma en las relaciones capitalistas y colonialistas); según ellas, las mayores víctimas de la ciencia son las mujeres y niños del hemisferio Sur y la naturaleza no humana. Tal sería el resultado de las oposiciones binarias patriarcalescapitalistas hombre/mujer, hombre/ naturaleza, industrial/indígena, nor- 
te/sur, en un abordaje en el que la búsqueda de una "verdad universalizada" se asienta en la explotación de la tríada mujer-naturaleza-Tercer Mundo. Si consideramos que el método de investigación-acción expuesto por Mies y Shiva es de sumo interés, para complementar la propuesta problematizadora de Freire (que sin embargo ellas interpretan mal, al considerar en una óptica psicologista y no dialéctica, que el desvelamiento crítico de la realidad antecede a su transformación emancipatoria), divergimos de la crítica a la "verdad universalizada" realizada por ambas. Creemos que Karl-Otto Apel (1973) mostró de forma convincente que tres normas éticas sustentan implícitamente a los enunciados científicos, a saber, decir lo que pensamos que es verdadero (en el sentido de la verdad por correspondencia a los hechos, en sentido aristotélico), renunciar al egoísmo en la búsqueda consensual de tal verdad, y aceptar a cualquier ser humano como un compañero legítimo en esa búsqueda. (Obviamente, no consideramos que esa triple exigencia ética se realiza en el día a día de alienación, violencia y manipulación que es el capitalismo, pero ello no borra la triple exigencia ética que se oculta tras cada enunciado, exigencia que debemos postular realizable en el ecomunitarismo). Así nos sumamos a Apel y no a la lectura simplista del supuesto violentismo machista atribuido por Mies a la ciencia. Al mismo tiempo, y apoyándonos en la Teoría de los Actos de Habla de- sarrollados por Austin (1962) sostenemos que hace parte de cualquier enunciado (también científico), que es dirigido siempre a por lo menos un interlocutor real o potencial, el intento de convencer a ese interlocutor (en acción perlocucionaria, dijo Austin) de la corrección de nuestro punto de vista. Ahora, esa convicción de corrección presupone y abriga la postulación de una verdad universalizable. (Por eso tenían razón Sócrates y los sofistas, pues si el primero insistía en la búsqueda de la verdad única, los segundos Ilamaron nuestra atención sobre el irrenunciable componente perlocucionario del discurso). Ahora bien, según la segunda norma de Apel y según nuestra segunda norma, esa dinámica abriga la posibilidad de ser convencido por el interlocutor y cambiar nuestra postura, lo que, otra vez, confirma la apuesta en una verdad universalizable. La prueba palpable de eso es el hecho de que Mies y Shiva escriben artículos y libros, materializando su intención de que sus interlocutores accedan a la única verdad en el asunto debatido (de la que ellas pretenden ser las voceras), por ejemplo, que la ciencia es sinónimo de violenta opresión machista. Contra esa visión sostenemos que la afirmación de Mies de que "la ciencia y la tecnología actuales son ciencia y tecnología completamente militares" es de un simplismo generalizante inaceptable. Por su parte Shiva sostiene que a la ciencia, que es patriarcalmasculina se le opone un "principio femenino" que incluye tanto a la 
mujer como a la "naturaleza", a los pueblos indígenas y al Tercer Mundo, y esa autora llega a decir que en las sociedades premodernas centradas en la mujer, la actitud cognitiva y práctica fue de respeto para con la naturaleza (Mies y Shiva 1997, cap.VIII). Hacemos nuestras las palabras de las feministas Maxine Molineux y Deborah Lynn (1994, p. 21), cuando ponderan que "toda esa explicación se funda en una visión romántica de las culturas preilustradas, precoloniales y premodernas que se basaban supuestamente en el 'principio femenino' y en un orden natural concebido como esencialmente bueno", por lo que " una historia compleja se convierte en universal y homogénea", y donde la apuesta a un futuro que supere las dominaciones típicas del capitalismo se confunde con el deseo de volver a un pasado idealizado.

Ahora bien, creo que Mies ha planteado bien una cuestión decisiva en la relación entre ética y ciencia al abordar los "límites de la investigación". Dice Mies: "Puesto que el paradigma científico está basado en el dogma de que el afán científico no conoce límites, genera una búsqueda orientada a ampliar cada vez más los conocimientos abstractos. No se permite ninguna interferencia moral en el proceso de investigación. Los científicos, por tanto, no pueden dar respuestas por si mismos a los problemas éticos" (Mies y Shiva 1997, cap. III). Aquí tocamos el difícil problema de la autocensura ética de la investigación científica y del uso de la ciencia. Nuestra primera norma ética (referente a la libertad individual de decisión) parece garantizar la ausencia de límites en la investigación. Pero nótese que esa norma puede y debe ser completada por las otras dos, y éstas, o en función de la ausencia de consenso, o en función de eventuales perjuicios a la preservación-regeneración de una naturaleza humana y/o no humana saludable, pueden perfectamente amparar la determinación de poner límites a la pesquisa. Y es importante resaltar que se trata aquí de autocensura ética inmanente, y no de cualquier censura exógena (como lo son las de corte religioso, como la que afectó a Galileo, o ideológico, como la impuesta por Lyssenko a la genética soviética). Tal autocensura es posible, necesaria y realizable en el marco de los Casi-Razonamientos Causales que son las normas éticas, que es el de las pautas de conductas establecidas, derogadas y renovadas mediante argumentaciones. Siendo así las cosas, es obvio que los límites impuestos por la autocensura ética de la ciencia son mutables históricamente según el estado de lo que juzgamos verdadero y debido; (y no olvidemos que en el ecomunitarismo postulamos que todos los seres humanos son desde la niñez practicantes de ciencia, puesto que se ha disuelto en la rotación de las tareas la "comunidad científica" estanque existente en el capitalismo). Así pues, en perspectiva ecomunitarista resulta claro que en materia de lo posible mediante 
la ciencia y la tecnología, las tres normas éticas nos dicen que no debemos querer todo lo que podemos, pues precisamente esas normas marcan los límites (históricamente mutables) de lo que debemos y no debemos querer.

\subsection{Prácticas políticas rumbo al ecomunitarismo: Historia y utopía}

Como MM (p. 91 y ss) y AA (en especial p. 276), consideramos que no hay determinismo ni necesidad en la Historia, la cual siempre permanece abierta a y según las decisiones tomadas por los individuos.

¿Cuál es el perfil de las prácticas que conforman el camino orientado por el horizonte ecomunitarista?

Para responder a esta pregunta, me permito hacer algunas observaciones conjeturales basadas en nuestra reciente experiencia histórica.

Creo que, si la fundamentación ética del proceso de liberación que apunta hacia el ecomunitarismo se apoya en la crítica del capitalismo, y en especial en la situación alienada de los asalariados en ese régimen social, no por ello la lucha de liberación puede definirse como una lucha de clases donde el papel de vanguardia está predeterminado y le corresponde a la clase obrera.

Ya se ha demostrado que la clase obrera, entendida como compuesta por los trabajadores industriales con contrato por tiempo indeterminado y comparada con lo que era a principios del siglo $X X$, ha disminuido cuantitativamente $y$ se ha transformado cualitativamente, como resultado de incorporaciones tecnológicas y organizativas al proceso productivo.

Además las organizaciones sindicales supuestamente representativas de esta clase transformada han visto mermar constantemente su número de adherentes, al mismo tiempo en que restringían cada vez más sus reivindicaciones a aspectos inherentes a la relación laboral asalariada vigente en el capitalismo (en busca de mejoras que no afectan esa relación como tal, y por eso no salen del marco del capitalismo) y se han mostrado una y otra vez omisas en relación a la problemática ecológica, defendiendo con la misma miopía de capitalistas y gobernantes, la supuesta prioridad del "empleo" ante el "medio ambiente", omitiendo el debate sobre la necesaria combinación de ambos en una sociedad sustentable desde el punto de vista socio-ambiental; en ese contexto, aún el tema nuevo del "asedio sexual" dentro de la empresa no ha sido vinculado, como lo propone, por ejemplo, el ecofeminismo, a una discusión general sobre el tipo y la legitimidad de las relaciones humanas afectivas, pedagógicas, productivas y comunicativas vigentes en el capitalismo en general (incluyendo el universo empresarial), en especial las que rigen entre ambos sexos, y entre los seres humanos y el resto de la naturaleza (sobre esto ver mi "Erótica",en López Velasco 1997, cap. I). 
A su vez, la gran mayoría de las organizaciones políticas supuestamente representativas de la clase obrera transformada han seguido el camino de las organizaciones sindicales, uniéndose de hecho, cuando no también de palabra al capitalismo reinante (y reinante con más fuerza después que, derrotado en Europa el Ilamado "socialismo real", el capitalismo es presentado por sus corifeos como "el fin de la Historia").

En las organizaciones políticas supuestamente representativas de la clase obrera que no han abdicado de sus ímpetus superadores del capitalismo, lo que se observa es una conducta marcada por un vacío de propuestas en lo que concierne al régimen deseado, cuando no una simple y simplista nostalgia y adhesión del/al "socialismo real" [régimen que, como, si no bastase la falta de perspicacia filosófica de los que así lo bautizaron (olvidando que ya el viejo Hegel decía que "todo lo que es real es digno de perecer"), no resolvió en la práctica ni la cuestión de la progresiva realización consensual de la libertad de individuos en proceso de universalización, ni la cuestión de la reconciliación con el resto de la naturaleza a través de una conducta ecológica de preservación y regeneración de la misma].

Estas constataciones son suficientes para aventurar la opinión de que la marcha histórica rumbo al ecomunitarismo no puede ser pensada como una lucha de conquista y/o recuperación del "socialismo real" teniendo a su cabeza a la "clase obrera", y a la cabeza de ésta a "sus organizaciones representativas", sindicales y/o políticas.

A la luz de la crítica éticamente fundamentada del capitalismo aquí antes desarrollada, y sobre cuyo telón de fondo se dibuja como alternativa el ecomunitarismo, esa marcha aparece como parte y producto de un proceso de "conscientização" (en el sentido de Paulo Freire, 1970) teniendo como protagonistas principales a los asalariados y excluidos del trabajo en general en el capitalismo (no se olvide que en 2008 la OIT registraba casi mil millones de desempleados y subempleados en el mundo), pero incorporando también a todo ser humano que sea capaz de entender y compartir con su praxis el alcance de aquella crítica.

Ahora, ¿qué formas organizativas habrán de darse esas multitudes?

Creo que la organización sindical y político-partidaria todavía tienen su lugar en la historia desde que su discurso cotidiano, además de velar por las reformas y conquistas puntuales tácticas legítimamente defendidas, apunte siempre hacia el objetivo poscapitalista perseguido, a saber, el ecomunitarismo, y desde que su funcionamiento interno esté marcado por la práctica democrática de las decisiones consensuales (siempre que posible en ejercicios de democracia directa) tomadas en base a la transparencia de las informaciones y, como parte de la cons- 
cientización en curso, los cargos directivos sean rotativos, evitando la profesionalización de los dirigentes en su función de tales.

Pero junto con y además de tales organizaciones piramidales, habrán de tener cada vez más fuerza aquellas que congregan a seres humanos en contextos "extraproductivos", preocupados con las cuestiones de la calidad socio-ambiental de vida, comenzando por su local de residencia. El restablecimiento de una vecindad solidaria y la acción en organizaciones no gubernamentales, atentas a la mejora de la calidad de vida en el barrio y el distrito, son tareas de primera importancia en lo referente al cambio de las relaciones interhumanas y a las de los seres humanos con el resto de la naturaleza.

La educación formal y los medios de comunicación son dos espacios fundamentales que la crítica ecomunitarista al capitalismo no puede abandonar en ninguna circunstancia, peleando por ocupar y/o crear el máximo de espacios posibles (en especial en las instancias de formación de profesores y en la radio y la TV). Las nuevas posibilidades tecnológicas en materia de comunicación hacen posible la abertura de brechas en la muralla que los grandes medios de comunicación (en especial, la televisión, el gran "aparato ideológico" del capitalismo actual, como podría decir Louis Althusser; ver Althusser, 1969) construyen diariamente alrededor del capitalismo, restableciendo el diálogo cotidiano con el colega, el vecino, y aún el desconocido. Las "sesiones sin televisión" en el barrio dedicadas a la discusión y al disfrute conjunto de la vida, la radio y la TV comunitarias (sumadas a los espacios institucionales o individuales que se pueda ocupar en los grandes medios de comunicación de masas), así como la conexión oportuna vía electrónica, teléfono, fax y carta, y el incesante diálogo cara-a-cara, son instrumentos de la acción política ecomunitarista en el área de la comunicación.

En la educación formal el gran desafío pasa por la práctica de la "pedagogía problematizadora" freireana, a través de la cual profesor y alumno construyen y renuevan a partir de sus vivencias su lectura crítica del capitalismo y su inserción transformadora en el proceso de liberación. En ese terreno el espacio clave es el de los centros de formación de profesores, pues a través de la formación problematizadora de los mismos se hace posible la multiplicación de la acción problematizadora a escala ampliada, en la medida en que se alcanza así al conjunto de sus futuros alumnos (que son millares a lo largo de una vida de docente).

Ese conjunto de espacios y acciones define el perfil de la marea ecomunitarista capaz de sumergir al capitalismo en el pasado de la historia (o, como dijo Marx, de la prehistoria humana). 


\section{Ecomunitarismo y globalización solidaria}

- n el tercer volumen de Ética - de la liberación (2000) discuto la política socio-ambiental ecomunitarista. En ese contexto afirmo que el ecomunitarismo tiene la dimensión planetaria de una globalización solidaria, lo que me lleva (aprovechando ideas de Fabio Giovannini, 1993) a marcar diferencias con un enfoque presente en varias de las actuales tendencias "verdes", el Ilamado "biorregionalismo", y a hacer precisiones al más conocido de los eslóganes verdes, aquél que pregona: "Pensar globalmente, actuar localmente".

Siguiendo el resumen hecho por Giovannini (Giovannini 1993, p. 70), podemos decir que el biorregionalismo consiste básicamente en las siguientes posturas:

a) Tenemos que vivir según las características de la región donde habitamos; o sea, vivir usando de modo ecológicamente sustentable los recursos de la biorregión en la cual se habita.

b) El uso de los recursos biorregionales debe ser sustentable, minimizado (mediante la reducción de insumos y residuos, cuyo reciclaje debe ser generalizado), practicando la protección conservacionista de la naturaleza y la agricultura orgánica. c) El núcleo político de la biorregión es la comunidad, siendo ella la que debe administrar la tierra mediante la práctica de una democracia participativa en la cual el momento de ejercer el voto es sólo un momento y no la totalidad del ejercicio democrático.

Giovannini destaca el hecho de que esta concepción puede llevar al aislamiento de "comunidades incomunicadas"; por otro lado ella no permite visualizar una solución para la cuestión de justicia atinente a la diferencia posible entre biorregiones pobres y ricas; también abre la brecha para que, en nombre de la biorregionalidad, la ecología se convierta en una modalidad más de un "funcionalismo sistémico luhmanniano" (que considera "reaccionario" pues el enfoque de Niklas Luhmann está "totalmente orientado a conservar poderes e intereses existentes, en primer lugar, el poder de la empresa capitalista"); por último, el biorregionalismo resulta inquietante por reabrir la puerta a una naturalización de las cuestiones sociales humanas, cuando se sabe que este punto de vista, al pregonar que la vida política y social de los hombres debería imitar el mundo natural, "puede legitimar violencias, racismos, discriminaciones, darwinismos sociales y autoritarismos" (ídem). 
Por mi parte, quiero destacar que esta última prevención de Giovannini, así como las tres anteriores, requieren, para ganar legitimidad argumentativa, una fundamentación ética, que este autor no nos proporciona. Ahora bien, es precisamente esa fundamentación la que ofrece el paradigma ético que propongo; en especial, todas las objeciones de Giovannini quedan cubiertas por las dos primeras normas por mi deducidas.

Ahora, como ya lo he dicho, la aplicación de las tres normas éticas permite que, por primera vez, el "género humano" quede constituido como entidad real (dejando de ser meramente una categoría lógicolingüístico-biológica). Esto significa que, en base a la libertad de decisión garantizada por la primer norma, mas con las restricciones que aportan las otras dos (en lo referente al ejercicio consensual de tal libertad y a la actitud de preservación-regeneración de la naturaleza), la apuesta ecomunitarista logra superar las carencias aislacionistas y de justicia relacional, así como los peligros de legitimar opresiones en nombre de un sistemismo a-históri$\mathrm{co}$, detectados por Giovannini en el biorregionalismo.

Como dije antes, el Ecomunitarismo propone que las comunidades de vida se integren en una gran red, partiendo de lo local, para cubrir el planeta entero; mas esa articulación pasa por los "servicios" mutuos (que, en forma de reciprocidad solidaria gratuita, puede asumir la for- ma de un "potlach" planetario) prestados entre ellas, en una relación de coadministración de las cosas que impide que cualquiera de ellas se erija como opresora de cualquier otra. Como esa relación resulta de consensos argumentativamente establecidos, sucede que cualquier abordaje-organización sistémica pasa por el tamiz de la Historia que los seres humanos construyen en la medida en que se auto-producen, y que, por ser tal, resulta, aún cuando haya "funcionalidad sistémica", de la libre decisión, siempre renovable, de cada individuo y de cada comunidad.

Como dije alguna vez, lo que se propone el ecomunitarismo es algo así como una "ONU de las comunidades", en la cual todos los mecanismos de opresión militar, asimetría comunicativa y explotación económica existentes en la actual ONU, sean suprimidos en la fraternidad planetaria. [Esto supone, entre otras cosas, la construcción de pactos consensuales renovables de alcance planetario, que vengan a sustituir, organizados como CuasiRazonamientos-Causales (cfr. López Velasco 1996) el actual Derecho Positivo, que a nivel de la ONU se constituye en gran parte como expresión del "derecho del más fuerte"].

En este contexto, si es verdad que debemos "pensar globalmente y actuar localmente", no es menos verdad que debemos también "pensar localmente y actuar globalmente", y aún "pensar globalmente y 
actuar globalmente". Porque algunas cuestiones locales solamente son solubles cuando la acción global tenga éxito (como sucede con el combate al aumento del agujero de la capa de ozono, que afectando con más intensidad la extremidad sur del continente americano, solamente es superable si a nivel mundial son tomadas medidas para la reducción de las emisiones que originan tal agujero). Por otro lado, la disminución del "efecto invernadero" que a todos amenaza en el planeta, solamente será alcanzable si acciones globales logran disminuir las emisiones causadoras del fenómeno.

\section{A modo de conclusión (provisoria)}

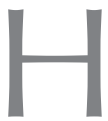

oy sabemos que, como decía Marx en El capital, el capitalismo arruina las dos fuentes de la riqueza: el ser humano y la tierra. En la lógica del lucro se sacrifica la salud humana en la angustia del desempleo y de la pobreza o en la jornada estresante, la violencia mata todos los días (por el petróleo, el color de la piel o por los zapatos de vecino, o por la droga, la pelea doméstica o el tránsito), el aire es irrespirable en las grandes ciudades, y las florestas sufren las consecuencias de la sed de ganancia y de la lluvia ácida, el efecto invernadero y el agujero en la capa de ozono modifican peligrosamente el clima y aumentan la incidencia del cáncer de piel, los ríos y mares son diariamente envenenados con ingentes cargas de materias tóxicas (en especial los agrotóxicos), que antes de llegar hasta ellos contaminan a las tierras y a las personas. Por todo eso el capitalismo se transformó en algo más que una amenaza a las rique- zas: pasó a amenazar la vida en el planeta entero. Mas el capitalismo tiene defensores poderosos que detienen el poder económico, militar y cultural. Todo el día la TV invade la casa de cada familia para decretar que otro mundo no es posible porque "el mercado" determina esto o aquello, al tiempo que en las escuelas y Universidades, incluso profesores bien intencionados insisten para que sus alumnos comprendan que deben prepararse para competir en el "mercado". Pero ¿qué es el "mercado" sino el conjunto de las relaciones productivo-distributivode-consumo entre las personas que escaparon a su control y gestión? O sea, aquel discurso de la TV y de los "educadores" significa que es normal y conveniente que la humanidad sea esclava de sus inventos interactivos y no la gestora de los mismos. Cabe a la educación ambiental discutir aquel estado de cosas y ese presupuesto. No en vano, incluso el organizador de la "Río 92" manifestó en aquella conferen- 
cia de 1992 que la discusión ambiental necesitaba cuestionar el actual modo de practicar la economía. Es bueno recordar que esa palabra deriva del griego "oiko-nomia", que en la era clásica designaba la gestión de las necesidades de la casa (oikos), para que nada necesario le faltase. El capitalismo realizó el "milagro" de invertir a tal punto las relaciones, que quiere hacernos creer que el ser humano debe amoldarse a la Economía, y no lo contrario. Ese es otro absurdo que debe ser cuestionado. Para dar cuenta de esa inmensa tarea la EA necesita (y resumo a mi modo la pretensión de la conferencia de Tbilisi) abarcar conjuntamente la ética y las áreas del conocimiento y de las habilidades; todas ellas apuntan hacia un nuevo comportamiento. Creo que la ética capaz de pedir-obtener adhesión universal (independientemente de todo credo religioso o a priori ideológico) es la de las tres normas que expusimos antes. Ella resume en un solo haz la fundamentación de la liberación humana y de la preservación-regeneración de la naturaleza no humana, y apunta hacia el ecomunitarismo, horizonte utópico en el que los seres humanos se reconcilian solidariamente entre sí y ecológicamente con el resto de la naturaleza. Si alguien dice que la realización del ecomunitarismo es imposible yo podría concordar de buen grado, pero subrayando que el ecomunitarismo es una estrellaguía indispensable para la acción, y que como toda utopía, "sirve para caminar", y sin la que nos quedamos sin rumbo en la acción cotidiana, incluso cuando estamos animados de muy bunas intenciones. Sospecho que buena parte del malestar de la juventud de hoy, masacrada por un sistema capitalista que la obliga a estudiar y después le niega la oportunidad de ejercitar aquello que aprendiera, viene, también, de esa falta de horizontes más allá del día-a-día frustrante y sin amanecer. El ecomunitarismo es la bandera que asumiendo esa realidad, presenta a la educación ambiental (EA) el desafío de asumirlo como guía; o sea, retomando el lema del movimiento estudiantil de mayo de 1968, de ser realista, pidiendo lo imposible, y, para tanto, llevar cada día la imaginación al poder. Esa EA debe ocupar los espacios de la educación formal y extenderse a la comunidad, a través de las redes, las familias, las ONG's, las asociaciones de barrio, los movimientos sociales, los sindicatos, los partidos, los comunicadores ganados para la causa y de los líderes religiosos cuando descubran que la "religión" consiste etimológicamente en re-ligar los seres humanos entre sí y con el resto de la naturaleza. Tal EA problematizadora tiene en Paulo Freire a su principal precursor y mentor, y se asume como actividad "política", o sea, viviendo y apuntando a la transformación de la "polis" (la ciudad-país-planeta) en la búsqueda de la aproximación asintótica al ecomunitarismo. Su radio de acción va desde el distrito hasta el planeta entero, creando los espacios de reflexión y actividad 
conjunta (de los cuales el Foro Social Mundial ya es un buen ejemplo que debe ser mejorado en su capacidad de intervenir con eficacia en la concretización de soluciones para los problemas socioambientales claramente diagnosticados desde hace tiempo). Enemiga de la violencia porque basada en la ética argumentativa, esa EA no teme, no obstante, reconocer que, así como se amarra a una persona víctima de un ataque de locura para que no lastime ni se lastime, así también es posible que haya que ejercer coacción sobre los ciegos capitalistas que con su acción prepotente nos

\section{Biblografía}

ALTHUSSER, Louis (1969). Idéologie et apareils idéologiques d' État, La pensée, París.

APEL, Karl-Otto $(1973,1988)$. Transformation der Philosophie, Suhrkamp, Frankfurt. La transformación de la filosofía, Taurus, Madrid, 1985.

ARTETA, Aurelio (1993). Marx: valor, forma social y alienación, Ed. Libertarias, Madrid.

AUSTIN, J.L.(1962). How to do things with words, Clarendon Press, Londres; cito de la Ed. Oxford Univ. Press, London-N. York, 1984.

CHOMSKY, Noam (1969). La linguistique cartésienne, $\mathrm{Ed}$. du Seuil, París. llevan (y van ellos mismos y sus familias o descendientes) rumbo al abismo del holocausto de la especie (y de muchas otras especies). Para hacer posible un mundo de personas pacíficas esa EA no puede huirle al combate, pues eso significaría dejarle el terreno libre a los vampiros del dinero sin función ecológica, que son los dueños del mundo de hoy. Para realizar lo que de ella se espera, la EA ecomunitarista debe aprender a combinar la enseñanza-aprendizaje de la sala de aula con la acción comunitaria (a través de todas las instancias recién mencionadas).

DOMINE, J. (1992). Ciencia y Fraude, en Relaciones № 100, Montevideo, septiembre de 1992.

DUCROT, O (1972). Dire et ne pas dire, Hermann, Paris.

ECOLOGÍA POLÍTICA, Ed. FUHEM/ ICARIA, Madrid-Barcelona

FREIRE, P. (1970). Pedagogia do Oprimido, Paz e Terra, Rio de Janeiro.

FREUD, S. (1895-1939). Obras Completas ( 3 Vol.), Editorial Biblioteca Nueva, Madrid, 1968.

GARCÍA de Haro, Ramón $\left(1987 ; 1^{\text {a }}\right.$ ed. 1977). Karl Marx: El capital, Ed. Cultura Filosófica, Madrid.

GIOVANNINI, F. (1993) ¿La democracia es buena para el medio ambiente?, en Economía Política, No 5, p. 61 - 72, Icaria, Barcelona. 
HARVEY, D. (1989). The Condition of Postmodernity-An Enquiry into the Origins of Cultural Change, Basil Blackwell, Oxford. Condição Pós-Moderna, Loyola, S. Paulo, 1993.

KANT, Immanuel (1788). Kritik der praktischen Vernunft, Suhrkamp, Frankfurt, 1989.

KUHN, T. (1962). The structure of scientific revolutions, Univ. of Chicago Press, Chicago.

LÓPEZ VELASCO, Sirio (1993). Kapitalismuskritik und Diskursethik, in Raúl Fornet-Betancourt (Hg.) "Die Diskursethik und ihre lateinamerikanische Kritik", CRM, Aachen, p. 53-73.

LÓPEZ VELASCO, S. (1994). Ética de la producción: Fundamentos, CEFIL, Campo Grande, Brasil.

LÓPEZ VELASCO, S. (1996). Ética de la Liberación. Oikonomia, CEFIL, Campo Grande, Brasil.

LÓPEZ VELASCO, S. (1997).Ética de la liberación, Vol. II (Erótica, Pedagogía, Individuología), CEFIL, Campo Grande.

LÓPEZ VELASCO, Sirio (2000). Ética de la liberación. Vol. III (Política socio-ambiental ecomunitarista), EDGRAF, Rio Grande, RS, Brasil.

LÓPEZ VELASCO, Sirio (2003). Fundamentos lógico-linguísticos da ética argumentativa, Ed. Nova Harmonia, S. Leopoldo.
LÓPEZ VELASCO, Sirio (2003). Ética para o século XXI: rumo ao ecomunitarismo, Ed. Unisinos, S. Leopoldo.

LÓPEZ VELASCO, Sirio (2003). Ética para mis hijos y no iniciados, Ed. Anthropos, Barcelona.

LÓPEZ VELASCO, Sirio (2008). Introdução à educação ambiental ecomunitarista, Ed. FURG, Rio Grande.

MARTÍNEZ MARZOA, Felipe (1983). La filosofía de El capital, Ed. Taurus, Madrid.

MARX, K. (1844). ÖkonomischePhilosophische Manuskripte 1844, Rowohlt Taschenbuch Verlag, Hamburg, 1968. Manuscritos de economía y filosofía, Alianza, Madrid, 1970.

MARX, K. (1861-1863). Ökonomisches Manuskript 1861-1863, en Marx-Engels Werke, Tomo 43, Dietz Verlag, Berlín, 1990.

MARX, K. (1864-1894). Das Kapital [3 Bände], Ullstein, FrankfurtBerlin, 1969. El capital, Pueblo y Educación, La Habana, 1973, 1983.

MARX, K. (1863-1866). El capital, Libro I, Capítulo VI, (Inédito), Signos, B. Aires, 1971.

MIES, M. \& SHIVA, V. (1997). Ecofeminismo, Icaria, Barcelona;

MOLINEUX, M. \& LYNN, D. (1994) El ecofeminismo de Vandana Shiva y María Mies, in Ecología Política № 8, Icaria, Barcelona, p.13- 23. 
O' CONNOR, J. (1990a). Las Condiciones de producción. Por un marxismo ecológico, una introducción teórica, in Ecología Política № 1, Ed. Icaria, Barcelona, p. 113 - 130.

O' CONNOR, J. (1990b). Las dos contradicciones del capitalismo, en Ecología política $N^{0} 3$, Ed. Icaria, Barcelona, p. 111 - 112

POPPER, K. (1959). The Logic of scientific discovery, Hutchinson, Londres.
PRIOR Olmos, Ángel (2004). El problema de la libertad en el pensamiento de Marx, Ed. Biblioteca Nueva/Universidad de Murcia, España.

REYES MATE, Manuel (2008). Justicia de las víctimas, Ed. Anthropos, Barcelona.

REYES MATE, Manuel (2009). El trapero y la política, en El País, Madrid, 22/03/2009, p. 31 